Portland State University

PDXScholar

$5-1-1967$

\title{
The emergence of the large lumber producers and their significance to the lumber industry
}

Kaye L. Darby

Portland State University

Follow this and additional works at: https://pdxscholar.library.pdx.edu/open_access_etds Let us know how access to this document benefits you.

\section{Recommended Citation}

Darby, Kaye L., "The emergence of the large lumber producers and their significance to the lumber industry" (1967). Dissertations and Theses. Paper 461.

https://doi.org/10.15760/etd.461

This Thesis is brought to you for free and open access. It has been accepted for inclusion in Dissertations and Theses by an authorized administrator of PDXScholar. Please contact us if we can make this document more accessible: pdxscholar@pdx.edu. 
AN ABSTRACT OF 'THE' THISTS OF:

Kaye L. Darby for the Degree of laster of science in Teaching

Date thesis is presented: _ay 25, 1967

Title: The Emergence of the Large Lumber Producers and Thejr Significance to the Iunoer Industry

fibstrect approved:

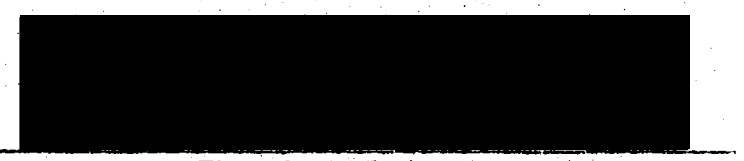

Thesis fovisor 


\section{THFSIO ABSTRECT}

The lumber industry today is both similar to and different from the nation's other major industries. The similarity stems from the fact that all of these industries have had a definite, well-defined transition period from an era dominated by many small, independent entrepreneurs to an era dominated by a smell number of large corporations. The dissimilarity between the lumber industry and the other industries is that with the lumber industry the domination by the few large firms has never been as total in scope as that domination by the giants of such industries as oil and transportation.

This dissimilarity has been the cause of no small amount of discussion and tension between various individuals and groups interested in the continued well-being of the lumber industry. The opponents of the large corporations claim that the trend in the lumber industry toward domination by a few firms has been just as complete as that experienced in other industries. Not only has it been complete, they claim, but the extensiveness of this domination has had a negative effect on the whole lumber industry, stifling competition and drivinét the small, independent operator from the scene.

Those who support the theory that this domination of the Iumber industry by the few large firms has never been completed on a basis comparable to other industries can offer much factual proof to support their argument, and in doing so much evidence can also be of fered to refute the theory that this rise to positions of seeming dominance by a few 
lumber producers has had a bad effect on the industry. These advocates of the cause for "Big Iumber" argue that if it hed not been for the emergence of a few strong leaders in the lumber inclustry, giving to the industry the direction and guidance it so baujy needed, commercial Iumbering on a large scale may have been doomed in the United States.

The purpose of this thesis is to open this argument once aigain with the intention of proving that certain lumer producers did emerge to dominate the industry although that comination was never complete. Also, the attempt is made to present a sound case in favor of these large lumber firms as being the instruments which were actually to save the lumber industry and to guarantee its permanent future existence. The method used to prove this position will be that of a detailed historical study of the early lumber industry in the United States from colonial times until shortly after the turn of the present century. Such a study is definitely needed for it reveals the complete story of why it was possible for a few firms to gain a high degree of control over the entire industry and yet still allow for the existence of a vast number of smaller, independent competitors. Also, such a study reveals how the transition was accomplished. Finally, through the examination of the lumber industry's early history, one is able to see quite clearIy the significance of this movement to the modern Iumber industry. The evidence unveiled by this study goes far in support of a major theme of this thesis, namely that the positive industrial leadership and influence generated by these few large lumber producers more than of any ill effects their growth had on the lumber industry. 
APPROVED:

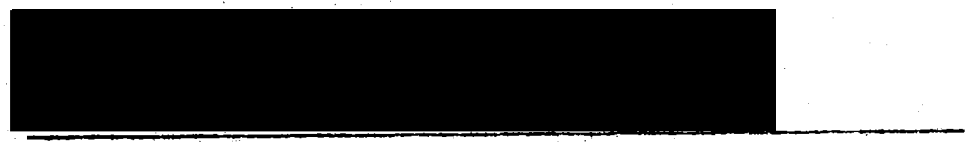

Thesis Advisor
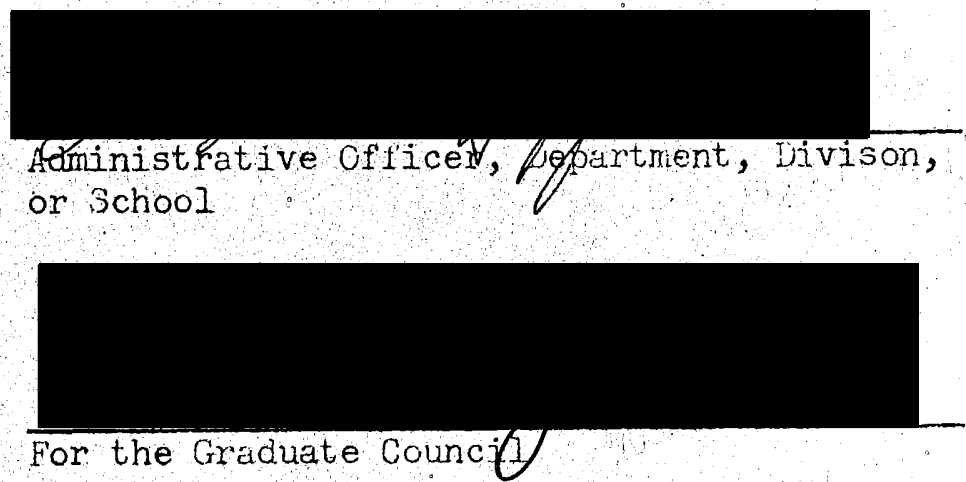

Jate thesis is presented:_ May 25, 1967 
THE FMERGFNCE OF THE IARGE IUNBIR PRODUCFRS AND THEIR SIGN FICANCE TO THE LUNGBE IINDUSTIRY

by

Kaye L. Earby

A THESTS

Presented to the Department of Hjstory and the Graduate Council of Portland State College in pertial fulfijiment

of the requirements for the degree of Haster of Science in Teaching Nay, 1967 
TABLE OF CONTENTS

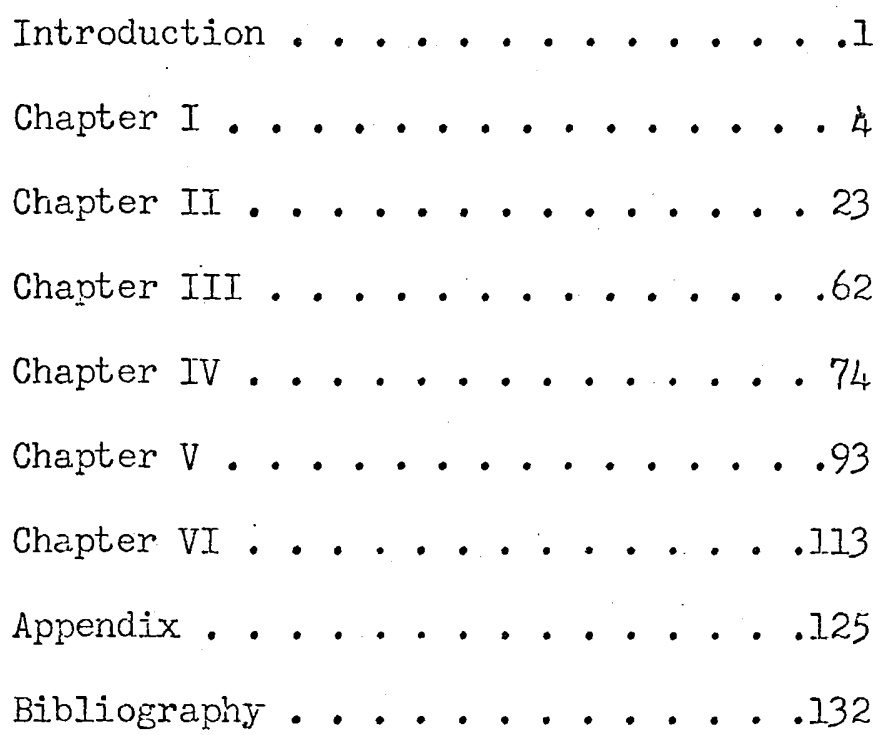




\section{IIST OF TABIES}

Table 1 Population Trends in Michigan Lumber Centers, 1890-1900 • • 19

Table 2 Population Trends in Michigan Non-Iumbering Towns, 18901900 . . . . . . . . . . . . . . .

Table 3 Population Trends in the States Bordering the Upper Mississippi, 185-1900 . . . . . . . . . . . 24

Table 4. Increase in Railroad Nileage, 1870-1890 . . . . . . 25

Table 5 Increase in Railroad Cars, 1887-1900 . . . . . . . 27

Table 6 Timber Holdings in the Pacific Northwest and California of the Three Iargest Private Owners, $1912 \ldots$. . . . . . 8

Table 7 Lumber Froduction of the Weyerhaeuser Timber Company, 19021913 . . . . . . . . . . . . 102

Table 8 Timber Sources of Western Oregon Sawnilis, 1960 . . . . I15

Table 9 Timber Holdings in the west of the Southern Pacific Railroad, 1912 . . . . . . . . . . . 126

Table 10 Timber Holdings in the West of the Veyerhaeuser Timber Company, 1912 . . . . . . . . . . . 127

Table 11 Total Weyerhaeuser Syndicate Timber Holdings in the Entire Nation, 1912 . . . . . . . . . . . . 128

Table 12 T'imber Holdings in the West of the Northern Pacific Railroad, 1909 . . . . . . . . . .... 129

Table 13 Leading States in the Production of thite Pine Lumber,

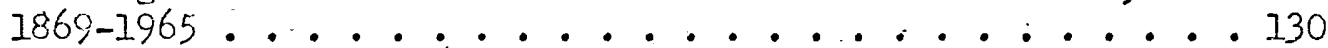

Table $I_{4}$ Leading. States in the Production of Douglas Fir Lumber, $1869-1965$. . . . . . . . . . . . . . . . . . . . . . . . 


\section{INTRODUCTION}

A key factor in the economic success of the United States lies in the integration and concentration of the majority of the nation's industrial power within the hands of a small number of large firms. This phenomenon is in evidence in almost every industry today whether it be that of steel, mining, oil, transportation, or banking. Furthermore, this concentration of power has in almost every instance eliminated the small and medium sized processors of the country's basic resources, leaving only two, three, or a half a dozen industrial giants to control the given industry. A notable exception to this trend has been the Iumber industry. True, there was at the turn of the century a definite move toward this concentration of power within the lumber industry, and it was attained to a certiain degree, but the lumber industry still remains today relatively free of total domination by a few firms. How the leading elements of the industry were able to achieve this concentration and yet failed to attain complete domination is a fascinating story. To understand it completely, it is necessary to examine closely the early history of the lumber industry. Such a study reveals definite clues to possible reasons why the development of lumbering did not follow the standard pattern of development of big business in the United States.

However, before beginning such a study there must be a definition of terms and of subject matter to be covered in order to limit the topic and to bring the proper focus to it. This investigation concerns itself 
strictly with the lumber industry to the exclusion of other closely related industries, such as the paper pulp industry. This thesis is concerned with only that segment of the total timber industry which is engaged in the harvesting, sawing, and milling of timber into boards, framing lumber, and patterned lumber for use in general construction. As the study progresses, it will take into account related industries only as they presently affect the large, integrated timber processing corporations. Primary consideration will be reserved for the lumber industry as defined.

Also, there carl ano should be a limitation placed on the geographical Iumbering areas to be considered in this study. In examining the concentration of power within the lumber industry, the historical investigation may be restricted to the industry's development across the northern part of the Unjted States from New England through the Upper Midwest to the Pacific Northwest. In doing this we naturally exclude a major area of lumber proauction and history, namely the South. The reason for this exclusion is that the nature of the southern lumber industry and its development are basjcally different from that of the industry in the rest of the nation. In the South lumbering has tradiionally been centered around the small producer processing the native yellow pine for the southern market. Historically, there have been no rnass migrations of the industry from the South to other forest regions of the nation, and even within the South itself there has been no definite pattern of internal shifts of locale. True, the southern industry is in direct competition with that of the Pacific Northwest and other areas, and the southern lumber industry has contributed to the development of 
the industry in other regions through the efforts of such individuals as R.A. Iong and a number of other equally capable men who migrated from the South to the North and Far West. However, in the final analysis the differences between the South and the other lumbering areas in timber species, manufacturing methods and philosophy, product emphasis, labor force, and other considerations allow one to make this exclusion and thus limit the topic considerably. 
CHAPRER I

As any United States history book. will point out, the early colonists were quick to realize the potentials of the seemingly endless forests which they found up and dow the Atlantic seaboard. With this unlimited supply of timber it was only natural that the early logging and lumber business should spring up in all areas. As the trees were cleared from the land, the settlers used the logs to build their homes and their furniture. Beyond their immediate needs the colonists at first demanded only a sma.ll. amount of logs and lumber. I However, as the population grew and improved equipment came into existence, the colonists began to realize the importance of the forests. A lumber industry was created, primitive to be sure, but nevertheless one in which certain individuals could concentrate their efforts and produce not only enough logs and lumber to satisfy their own needs but also the demands of the surrounding area.

The Iumber industry, like most other industries during the colonial period, was characterized by the small independent operator, the more or less local trade area, and an unorganized labor force. As occupational specialization began to take place within each community, certain individuals, because of previous experience or natural inclination, became the early lumbermen of the area. These first sawmills were owned by individuals either alone or in partnership with others in the

${ }^{I}$ Curtis P. Nettles, The Emergence of a National Eiconomy (New York: Holt, Rinehart, \& Winston, 1962), p.277. 
community and were at best primitive. The lack of power-driven equipment necessitated the use of hand tools which caused the process of turning a log into lumber to be a long and laborious chore. The awkwardness and bulk of the logs did create a need for additional labor to help in the sawmills, but the nature of the work did not demand nay special skill. As a result, the early mill owners could hire any handyman to help, and when the job was completed, the extra help was released. Stili, these mills were able to meet the lumber demands of their local area. The homes and buildings of the early colonial period did not demand too many refinements in their construction, and since logs and later lumber needed for their construction could be easily obtained in the irmediate area, there was little need to look elsewhere for a supplier.

From the suppliers' standpoint, even if there had been a great demand from the outside for lumber, the lack of proper equipment, the inadequate labor supply, the lack of sufficient transportation, and the inexperience of the mill owners themselves in producing for a large market would have restricted the production of these early operations.

However, as time went by the population of the colonies grew, causing a great increase in the demand for lumber to be used in construction. There was at the same time a great increase in the demand from other areas, principally the domestic and foreign shipbuilding industry. As the European powers increased their drive for colonial possessions, the demand for bigger and better navies and merchant marines greatly increased the demand for Iumber. Great Britain and the Netherlands had wrestled the initiative away from Spain, and both nations were. 
greatly enlarging their fleets in order to meet the demands of their overseas empires. Not only did the British and the Dutch need ships for their colonial requirements, but both nations were also vying with each other to become the chief carrier for the exports of the other nations of the world. This particular demand for shipbuilding lumber had great significance for America's early lumber industry for both Great Britain and the Netherlands were almost completely deficient in forest resources. To meet their needs, both countries naturally turned to the American colonies, for it was in the forests of America that the Europeans found the type of timber which was ideally suited to their shipbuilding specifications.

Conversely, as the demand increased, the supply was increased sharply. Certain of the early lumbermen realized the profit possibilities of the expanded market and acted accordingly. Basic improvements were made in methods and machinery, and, together with the increased labor supply resulting from the growing tide of immigration, these innovations allowed the early lumber industry to meet the challenge. In doing so they began to get away from the provincialism of the original lumbermen. Improved and expanded communication systems, particularly roads and domestic shipping, were a great factor in this change. Improvement in the road system had made inland towns, such as Albany, New York and Lancaster, Pennsylvania, into busy commercial centers. 2 . In regard to domestic shipping the increase in tonnage which occurred in the late $1700^{\prime} \mathrm{s}$

2 Emory Johnson, History of Domestic and Foreign Comnerce of the United States (Washington, D.C.: Carnegie Institute, 1915), I, p. 204. The author points out that when the first turnpike in the United states was opened in 1792 between Philadelphia and Iancaster, "it probably carried more traffic than any other road of the day." 
and the early 1800's was no less dramatic. From a total of 447,754 gross tons in 1793 American shipping rose to 1,089,876 gross tons by 1807, signifying a corresponding increase in shipping traffic. ${ }^{3}$ No Ionger was a producer restricted to his own immediate trade area for the distribution of his product. Also, he was now able to make better use of the natural resource at his disposal. No longer was the sawmill in Pennsylvania, for instance, forced to cut oak trees into lumber to be used in home construction. For this purpose the carpenter was now able to buy the softer, less expensive pine and spruce lumber being shipped in from the New England states. This allowed the Pennsylvania lumberman to mill his oak especially for the furniture manufacturer, thus realizing a greater profit.

As a result of these changes the early American lumber industry began to take on its present form. By the early 1800's the industry found itself ranked second among the nation's industries in respect to size and importance. Only agriculture outdistanced the lumber industry. Figures on the value of exports of the United States during the period bear this out. From 1803 to 1815 the products of agriculture amounted to eighty percent of all exports while the value of forest products was second at eleven percent. Although it was a distant second, it is significant to note that the percentage ranking of forest products exported exceeded the totals of all other manufacturing industries and of fisheries combined. ${ }^{4}$

By 1800 a definite pattern of regional specialization had also taken

\footnotetext{
3Ibid., II, pp. $27-28$.

$4^{4}$ Nettels, Emergence of a National Economy, p. 277.
} 
shape. In the South the lumber industry began to concentrate not only on the manufacture of construction lumber for local consumption but also on the production of naval stores. In the Middle Atlantic states the main emphasis was placed on the processing of hardwood timber into fine furniture lumber and other specialty products. Finaliy, in New England the specialization took the form of the commercial lumber industry as it was defined earlier in this paper: namely, the processing of timber into lumber for general construction purposes. The forests of New England were really the birthplace for the present day lumber industry as it is now known in the Pacific Northwest. It was in New England that the early colonial lumbermen found the type of forest best suited to the production of the lumber most in demand for general construction purposes. Great stands of spruce and white pine were discovered. Both species were of great commercial value because of their wide acceptance by the building trade. In addition, the white pine was particularly prized for it was this wood that was so much in demand by the ship builders of that period. The long, straight, limb-free trunks of the mature pine trees were ideally suited for the superstructures and masts of the wooden sailing vessels. With a rapidly expanding market for their ships the American ship builders began to concentrate their yards along the New England coast to take advantage of the accessibility of the white pine. Naturally, the lumbermen were quick to follow suit in order to satisfy this demand. 5

Thus, by the beginning of the nineteenth century the American lumber industry had divided itself into distinct regions, and already 
within the separate regions there was beginning to take place the process of specialized concentration. Although it is impossible to ascribe exact dates to such phenomenon, it is possible to make some approximation. In this respect it is probably safe to say that by 1800 the lumber industry had entered into its second major stage of development. This stage was to last until the Civil War period, some sixty years later.

There was more to this first great concentration of the lumber industry than simply an apparently inexhaustible natural resource supply. As Stewart Holbrook points out in his delightful history of the American logger, Holy old Mackinaw, conditions were perfect in New England in general and in Maine in particular for the development of the industry. 6 Not only were there great forests, but they were honeycombed with several fine river systems, principally the Kennebec River and the Penobscot River. Besides being suitable for log transportation, these rivers had the added feature of emptying into the sea, making possible the needed connections with the major trade areas of the eastern seaboard and of the rest of the world.

In Maine, near the mouth of the Penobscot, the town of Bangor rapidly became the lumber capital of the world. Because of the natural conditions in Maine most of its early residents found their livelihood in the pineries. For the first time in America's economic history a given geographical region became dedicated almost completely to the production of lumber. Lumbering became the dominant and in some places the sole industry in Naine during the period between 1776 and the Civil

\footnotetext{
6Stewart H. Holbrook, Holy Old Mackinaw (New York: MacMillan, 1938), p. 14 .
} 
War. The entire economies of many communities became shackled entirely to the fortunes of lumber.

In this respect the labor force of the area was ideally suited to the industry. Not only was this labor force ready and willing to help Maine become the nation's top lumbering state, but they were also a most able group of men. One of the key reasons the industry concentrated in Maine was the abjlity of Maine's lumbermen to come up with the necessary technological advances. Naturally these first inventions were quite elementary, but it is significant that several, such as the peavey and the branding ax, are still. used by loggers today in their original form. As business increased, so did the stature of Bangor. In time the tow not only became à great lumbering center but also a great shipping port. In its heyday Bangor became the focal point of a tremendous concentration of logs, lumber, and ships. It is probable that there were almost as many fortunes made in shipping in Bangor during this time as there were in the production of Iumber. At times so many ships were anchored in the Penobscot River at Bangor and neighboring towns up and down the river awaiting their cargos of lumber that "small boys could walk across the harbor. . . on their decks." 7 However; just as fast. as Bangor's star rose in the lumbering heavens, it was to descend. Reaching its peak of Iumber production in the 1830 's through the early $1850^{\prime}$ s, the lumber industry in New England slowly began to show definite signs of dwindling prosperity. The conditions which had seemed so favorable and which had promised such an infinite period of prosperity suddenly changed. New England was to remain a najor lumber producing region long

\section{Ibid., p. 25.}


after it lost its place of prime inportance in the industry, but during the decade prior to the Civil War several economic factors had combined to move the main Iumber industry elsewhere.

In examining the reasons for this shift in geographical location of the major portion of the industry, one begins to see an underlying pattern of growth developing which will become characteristic of the Iumber industry as it moves from region to region. From this basic pattern or cycle of growth there developed many of the basic problems of the industry, some of which still plague it today. To begin with, Naine's supposedly inexhaustible supply of timber was being rapidly exhausted. The early industry put such a premium on perfect, defect-free lumber that the loggers cut only the very best trees, leaving the less perfect specjmens to stand or lie in the woods. Thinking they could cut Maine's prime timber forever, the early lumbermen gave no thought to reforestation. Cut-over land was left bare, to be taken over by marginal farmers who attempted to grow crops in a soil and in a climate suited primarily to the growth of trees. As a result, by the early $1860^{\prime}$ 's the resource was depleted to the point where further lumber produstion on a large scale was unprofitable.

Also, the lumber market was constantly changing. No longer was the East Coast the only major domestic trade area. As the frontier moved westward, the country's population began to move into the Middle Western states. To be sure, the eastern states remained heavy users of lumber. The major metropolitan areas along the coast were still growing at a rapid rate. New York City, for instance, by 1850 had attained a population of 515,547 . This represented an increase of some $800 \%$ over 
its population of 60,489 in $1800 .^{8}$ The demand for lumber by the eastern states certainly was not slacking. However, it was remaining rather constant since the initial construction of homes and buildings in the large cities had already taken place some years before. In contrast, the cities, towns, and farms of the Midwest were still in their initial phase of construction. In the Midwest during the $1800^{\prime} \mathrm{s}$ most construction was of new buildings, and as a result it created a great demand for lumber. The farmers, in particular, demanded vast amounts of lumber for their many buildings and general farm uses, such as fencing, watering and feed troughs, cribbing, wagon beds, etc. All of these, because of hard use, had to be kept in constant repair, and the farmer was his own carpenter. In this role he demanded improvernents in Iumber manufacturing and in lumber supply. For instance, hand split rails sufficed for fencing only until the lumber mills could supply finished boards. The labor saved by the farmer by using the manufactured lumber could now be used in the growing of his crops. The relative inexpense of the manufactured lumber meant that the farmer could afford to fence more of his land. The results were that the more lumber he got, the more the midwestern farmer wanted. This demand, coupled with that of the constantly growing towns and cities of the region, was insatiable.

These gains in demand more than offset the loss experienced in another major lumber market of the day, that of the shipbuilding industry. This industry, since colonial times a prime user of American Iumber, began to experience a steady decline in the manufacture of wooden vessels.

8U.S., Bureau of the Census, Seventh Census of the United States: 1850 (Washington: Robert Armstrong, 1853), p. lii. 
Upon losing their colonial possessions in America, the major maritime nations, particularly England, had gradually turned to the Scandinavian countries for their lumber. After the Revolutionary War the slack in foreign shipbuilding demands was taken up by domestic shipbuilding demands as the United States built her own navy and merchant marine. 9 However, by 1860 the industry had caught up with the demand. The advent of the Merrimac and the Monitor heralded the end of the era of the wooden vessel. Now the shipbuilders along the East Coast of the United States switched to iron and steel, thus drying up a very large portion of the early demand for lumber.

In answer to these changing conditions the lumber industry moved into the white pine forests of the Upper Midwest. This first migration was a natural one for the lumbermen, for in the forests of northern Michigan they found conditions almost identical to those which they had experienced in New England. Again, it was a vast white pine forest which appeared to be limitless and which held great profit possibilities.

9During the latter part of the eighteenth century until the outbreak of the Revolutionary War Great Britain was the prime purchaser of American built ships. At the beginning of the Revolution approximately thirty percent $(2,342$ out of 7,694 ships) engaged in the commerce of Great Britain were American built (Johnson, History of Domestic and Foreign Comnerce, I, p. 73). After the war the demand of American shippers and of the American Navy for American built ships steadily grew, event-ually offsetting the lack of British demand. Construction was slow. until 1789 when Congress passed the Tonnage Act which gave protection to the domestic shipbuilding industry and thus gave it the needed stimulus. Construction had reached a total of almost 100,000 tons by 1795, and it averaged 110,000 tons a year during the good years of 1801-07. The War of 1812 caused a depressed market, but by 1815 the industry had recovered enough to set a new record of 158,000 tons. This figure, when compared with the total of 24,000 tons produced prior to the Revolutionary War in 1769 is evidence that the loss of British demand was no longer being felt. (Nettels, Economic History of the U.S., p.239). 
The avajlable waterways and the closeness of the manufacturing centers to the major trade centers of the area also were much the same as the New England region. If anything was different, it was the efficiency of the Iumbermen themselves. In Maine they had done their original experimenting. In Michigan they could concentrate on improving these earlier methods and machines. Logging and milling technology began to effect great changes in lumber production. In Michigan the Saginaw River and the town of Saginaw quickly became the new center of lumbering in the world. By 18775 Saginaw and surrounding towns along the Saginaw River were blessed, or cursed, with 112 separate saw mills. 10 Capable of cutting over a billion feet of lumber in a single season with their new steam-powered equipment, these mills far surpassed anything Maine had to offer. By 1870 the value of the total lumber production for Maine had declined to $\$ 11,395,747$ which was approximately 5.5 percent of the total value of the nation's lumber production. In contrast, ten years later Michigan's total production was valued at. $\$ 52,448,928$, and the state accounted for 22.5 percent of the total value of lumber production in the entire United States. Il At the height of its lumber production period between 1870 and 1895 Michigan's economy took on much the same flavor as had that of Naine. Lumber was king, and all other businesses in such communities as Saginaw, Bay City, and Muskegon revolved entirely around the fortunes of lumber. However, the great advances in technology which had made such suc-

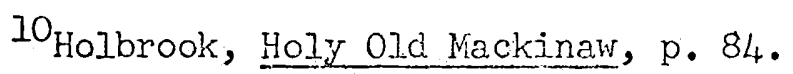

11. U.S., Bureau of the Census, United States By Industries: Manufactures - 1905 (Washington: U.S. Government Printing Of'fice, 1907), p. 162. 
cess possible were also among the chief causes for the decline of Michigan as the leading lumber producing state. The steam driven saws in the mills put constantly increasing pressures on the loggers in the woods to produce more and more logs. Michigan reached its peak as a lumber producer in 1890 when the total value of its lumber production was $\$ 83,121,969.12$ The apparent health of the economy was deceiving. By 1890 the prime white pine forests of the state were practically gone, and in the years which followed the producers had to settle for logs of poorer grade. Production for Michigan slipped in value to $\$ 53,915,648$ by 1900.13 The mills of the Saginaw area were hit extremely hard. In fact, by 1895 only a handful of mills were still operating along the Saginaw River, and even these were so hard pressed for an adequate log supply that they were actually bringing logs to Saginaw from Canadian sources. However, this venture proved unsatisfactory, for the Canadian woods were too far from the Saginaw mills to be profitable.

Conservation theories unfortunately had not kept pace with the changes in methods and equipment. The mistakes of Maine were repeated in Michigan where the emphasis was also placed on short term profit. Basically, there had been little or no attempt made in Michigan to replenish the cut-over land. Conservation and profit seemed to be incompatible in the eyes of the lumbermen. With so many trees available, the loggers saw no reason to be very scientific in their logging methods. Only the choice, mature timber was sent to the mill, and the remaining trees which failed to make the grade were either left standing or were

12 Ibid.

13 Ibid. 
cut and left lying in the forest. Unlike the scientific method of selective logging which is now practiced in the pine regions of the West, this was a random, haphazard skimming off of the cream of the timber crop while leaving the remainder of the resource to spoil. The logged-over forests, when left to themselves, often became either the starting points for insect and disease epidemics which threatened the remaining timber or the sources for disastrous fires which often destroyed many acres of choice timber in surrounding areas.

These fires not only destroyed the standing timber but sterilized the soil to such an extent that it was often impossible to regenerate the forest immediately. Fire, destroying the nitrogen content of the already low fertiljty forest soj.l, lowers the soil fertility even more. If seeds of the commercially valuable species, such as the pines or the firs, do survive the fire, it is unlikely that they will take root in the sterile soil. In their place will come instead other species of plants and trees which can exist under such conditions and which begin the process of building the soil to its former level. This cycle could take several hundred years. Only in cases such as Oregon's Tillamook Burn, where seedlings have been transplanted by hand, can the cycle be broken and the mature forest be regenerated more quickly. The early Iumbermen of Maine and the Upper Nidwest gave no thought to such matters. It was far easier and more in keeping with their short term profit motives to "cut out and get out."

At the mill level there was likewise no thought given to conservation. The sawmill waste burners were aglow day and night as producers cut for only the higher grades of lumber. At the time the lower grades 
had little utility, and the mill owners made no attempt to develop markets for the lower quality lumber or for lumber cut from the so-called weed species, such as Norway pine, jack pine, and hemlock. These were considered waste and as such were often burned. The mills only multiplied the unsound conservation practices of the loggers in the woods.

The earlier failures in conservation in Maine had failed to impress upon the Michigan lumbermen the need for a sound conservation program. This lack of conservation on all levels more than of set the short term prosperity of the Iumber industry in Nichigan. In less than fifty years the lumbermen had cut themselves out of raw material, and richigan lost her claim to the lumber throne.

In analyzing this early period in the lumbering history of the United States, it is interesting to note several things which are most helpful in the understanding of the present status of the industry. The industry's first great concentration in Maine and its first major migration westward to Michigan reveal a definite pattern which was repeated with each new migration. The practices of the early lumbermen laid the foundations for some of the basic problems which have plagued both the industry and the nation ever since. The short term, high profit motive led directly to the adoption of the "cut out and get out" policy which made the lumbermen few friends. Their insistence on immediate profit made them concentrate on satisfying only the areas of greatest demand, supplying only the best of the resource. Iittle or no thought was given to the possibilities of developing demands for the lower grades of lumber or for the lumber from the weed species. As a result, in both Waine and Michigan only the prime spruce and pine were used while the remainder of the timber was left in the woods or burned. This problem became more 
acute as new methods and machinery were developed in the industry. With each new innovation the process of "cut out and get out" was accelerated just that much more. Maine's industry lasted a relatively Iong time compared to that of later regions. But by the time of the industry's move to Nichigan the process was so intense and swift that Saginaw's prominence in the lumbering industry was relatively short lived. Whereas Bangor had enjoyed over one hundred years as a lumber producer, Saginaw was to last only about sixty years and only during the last twenty five of these years was Saginaw the country's leader in Iumber production. The end in the Saginaw area also came much more abruptly. Hitting its peak production years in the 1870's and early 1880's, Saginaw was completely through with large scale lumber production by 1895 .

The lumbermen had become their own worst enemy. The very things that had made many of them wealthy were now bring adverse economic effects to wide areas. The results of these practices were found in the ghost towns, the depressed economic areas, and the lack of conservation of one of the nation's basic resources. Saginaw in its prime as a lumbering center never exceeded a population of thirty thousand, and yet it had a most vibrant economy, just as had Bangor during its prime. The other lumber producing towns of Michigan appeared to have the same economic health. Yet, by 1895 and for many years to follow many of these same towns in the Iumber producing areas of Michigan had become practically ghost towns. The larger communities became economically dormant, and their populations either remained stagnant or diminished during the lean years of the late 1.800's and early 1900's. As the fol- 
lowing chart shows, the population trends of the two leading lumber centers, Saginaw and Bay City, were quite similar in these years:

TABLE 1

POPULATION TRENDS IN MICHIGAN LUMBER CENTERS, $1890-190014$

$\begin{array}{lcc} & 1890 & 1900 \\ \text { Saginaw } & 46,552 & 42,345 \\ \text { Bay City } & 27,839 & 27,628\end{array}$

In contrast, the towns of southern Michigan which were not dependent on lumber showed a constant population growth over this same ten year period. Jackson and Kalamazoo, for instance, exhibited the following trends:

TABLE 2

POPULATION TRENDS IN MICHIGAN

NON-LUMBERING TONNS, $1890-1900^{15}$

$\begin{array}{lcc} & 1890 & 1900 \\ \text { Jackson } & 20,798 & 25,180 \\ \text { Kalamazoo } & 17,853 & 24,404\end{array}$

By 1910 the influx of the brand new automobile industry had given some towns, such as Saginaw, a new lease on life, but the smaller towns were not so fortunate. The timberlands surrounding these towns were bare; and the mills were either shut down completely or were operating at only

${ }^{14}$ U.S., Bureau of the Census, Abstract of the Thirteenth Census: 1910 (Washington: U.S. Government Printing Office, 1.913), p. 64 .

15 Ioid. 
a fraction of their capacity. The $\$ 83$ million peak year for the Michigan lumber industry in 1890 had dropped off drastically to $\$ 54$ million by $1900^{16}$ This drop of approximately thirty five percent foretold a bleak future, and the operators began to take their capital elsewhere in hopes of repeating the process which had proven so successful.

In doing so, they also forced the labor supply to move on. By the time of the Iumber industry's Nichigan exodus this labor force was definitely at the mercy of the owners of the mills and the logging companies. Largely unskilled and completely unorganized, they were becoming nothing more than a transient labor force completely dependent upon the whims of the operators. The majority of the loggers and sawmill hands who made up this labor force knew no other trade. Not only was it their life, but it had been the life of their fathers and grandfathers. In addition to this association by birth with the lumbering life, most men in the forest regions naturally took to the vigorous and often dangerous Iife in the woods or in the mills. Sawdust gradually got into their veins, and once smitten they could not break away. In becoming lumbermen, even on the level of common labor, they too accepted the prevailing industry practice of constant movement. It was only reasonable that when the trees were all cut the logging and mill operations would have to move on to the next stand of timber. If a man wished to keep working, he too had to move on for there was usually no other market for his labor in the vacated town. The westward movement of the industry dictated the westward movement of the labor force associated with lumbering, and as a result the lumber regions of Michigan and later Wisconsin and Minnesota

$$
\text { 16.S. By Irdustries: Manufactures - 1905, p. } 162 .
$$


suffered untold economic hardship.

The people who decided to remain behind found little chance to better their economic positions since there was nothing to fill the industrial void. In many cases people had to go on relief to exist. Some communities, such as Saginaw, eventually found economic relief with the coming of the automobile industry and other industries, but many depressed areas of the Lake States remained unsolved economic problems. In describing this plight during the 1930's, Vernon Jensen in his book, Lumber and Labor, traces the primary causes for the economic problems in these areas directly back to the migration westward of the Iumber industry.

The relief problem in the cut-over area during the decade of the thirties was the most acute in any of the three Lake States. This is definitely a result of unsolved problems of a decadent industry. The recent - and in many cases ill-advised - settlement, the relative cultural heterogeneity of the region, the isolation, and the depletion of the natural resources are all factors which helped to produce the extremely high relief rate and the meager standard of living. The relief problem has been "an agricultural one only in that many of those usually employed in non-agricultural industry had turned to agriculture after losing jobs...." More than onefifth of all the households on relief in June, 1935, consisted of persons living alone. "These were cases of former woodsmen or of isolated individuals who had settled on a piece of land or in a village in the Cut-Over Area when the timber had been cut." In addition, unemployability has been more serious in this region than in other parts of these states. "The area contains an usually high proportion of elderly unattached men, former lumberjacks . . . ." The depression simply revealed the effects of the long-declining lumber industry and the failure to do anything sufficiently constructive to solve the many problems it left behind.17

However, in the middle and late 1800 's little heed was given to these ominous signs. Toward his almost captive labor force the mill owner's a.titude was hardly benevolent. Long, hard work in the woods

${ }^{17}$ Vernon H. Jensen, Lumber and Labor (New York: Farrar \& Rinehart, Inc., 1945), ?. 67 . 
or in the mills was rewarded with poor pay and even poorer working conditions. Labor, being unorganized and lacking a favorable bargaining position in respect to having other job opportunities available, was unable to retaliate. In regard to the natural resource, the future timber supply was merely taken for granted both by the lumbermen and by the American public. The feeling on the part of the general public during the latter part of the nineteenth century was that the main concern should be to use the timber immediately to build the nation and let the future take care of itself. With this favorable attitude on the public's part, the lumbermen faced little oppositon as they placed more and more emphasis on the profit motive, and the successful operator gave little thought to the exploitative nature of the means he was using to attain his personal ends. The ends justified the means. After all, there had always been and would always be another inexhaustible stand of timber, bigger and better than the last stand, just waiting over the next hill. 


\section{CHAPTER II}

The forests of northern Wisconsin and northern Minnesota were the next stop for the hungry lumbermen. Actually, the development of the Iumber industry in the Upper Mississippi Valley regions took place almost concurrently with that of the industry in Michigan. With the decline of Saginaw as a major lumber producer in the 1880's, the jmpetus shifted first to Wisconsin and then to Minnesota, and by 1890 the new center of the industry was located in and around the northern Minnesota town of Cloquet. Situated a short way up the St. Louis River from Duluth, the heavy concentration of sawmilis in and around Cloquet were in time to make it the last great lumber center of the Midwest. ${ }^{1}$

To understand why this second migration took place, it is not enough to know what caused the decline of the industry in Michigan. One must also examine the economic conditions in the Upper Midwest during this period, for important changes were taking place between 1850 and 1900 in the economy of this region which greatly affected the development of the lumber industry in the Upper Mississippi Valley. Of prime importance was the tremendous increase in population in the Midwest. The fertile, plentiful, and inexpensive farm lands of the Midwest coupled with equally attractive economic opportunities in the growing towns and cities of the region acted as a magnet drawing an ever increasing surge of population westward. This population growth was particularly signifi-

Ralph W. Hidy, Frank E. Hill, and Allen Nevins, Timber and Men: The Weyerhaeuser Story (New York: Nacmillan, 1963), pp. 188-204. Also, see Holbrook, Holy Old Mackinaw, pp.117-18. 
cant in those states along the Upper Mississippi River, as is show by the following chart:

TABLE 3

POPULATION TRENDS IN THE STATES BORDERING THE UPPIR NISSISSIPPI $1850-1900^{2}$

$\begin{array}{lrcc} & 1850 & \underline{1900} & \begin{array}{c}\text { Approx. Percent- } \\ \text { age Increase }\end{array} \\ \text { Illinois } & 851,470 & 4,821,550 & 570 \% \\ \text { Iowa } & 192,214 & 2,231,853 & 1,160 \% \\ \text { Minnesota } & 6,077 & 1,750,394 & 2,920 \% \\ \text { Wisconsin } & 305,391 & 2,069,042 & 680 \%\end{array}$

With this growth in the market there naturally came a great increase in lumber demand. In addition to this increase in demand on the part of the individual consumers there was also at this time a tremendous increase in lumber orders from the railroads. This period between 1850 and 1900 was the peak time for railroad expansion. During the twenty years from 1870 to 1890 the total railroad mileage of the nation jumped from a meager 52,922 miles to a total of 166,703 miles. ${ }^{3}$ Although nationwide in scope, a large percentage of this increase was in the Midwest. In the areas immediately adjacent to the Iumber regions of the Upper Midwest this increase in railroad mileage was most significant to the great increase in Iumber prociuction.

2U.S., Bureau of the Census, Statistical Atlas of the United States: 1900 (Washington: U.S. Govemment Printing Office, 1903), Plate 19.

3U.S., Bureau of Statistics, Statistical Abstract of the United States: 1901 (Vashington: U.S. Government Printing Off'ice, 1902), pp. 39091. 
TABIE 4

INCREASE IN RAIIROAD,

NIIEAGE, $1870-1890^{4}$

\begin{tabular}{|c|c|c|c|}
\hline & 1870 & 1880 & 1890 \\
\hline $\begin{array}{l}\text { Group I } \\
\text { (Ohio, Michigan, Indi- } \\
\text { ana; Illinois, and } \\
\text { Wisconsin) }\end{array}$ & $\Psi_{4}, 701$ miles & 25,109 miles & 36,976 miles \\
\hline $\begin{array}{l}\text { Group II } \\
\text { (Iowa, Minnesota, North } \\
\text { Dakota, South Dakota, } \\
\text { Nebraska, Montana, and } \\
\text { Wyoming) }\end{array}$ & 5,004 miles & 12,347 miles & 27,294 miles \\
\hline
\end{tabular}

of these particular states shown in Table 4 only Wisconsin and Minnesota possessed the necessary sof.twood timber resources needed to supply the demands of the railroads for lumber. The close proximity of the forests of Wisconsin and Minnesota to the major railroad construction areas and to the principal railroad equipment manufacturing centers, coupled with the relatively easy transportation to these markets afforded by the Mississippi River and the railroads themselves naturally made the Iumbermen of the Upper Mississippi Valley the logical suppliers of this great demand.

This tremendous increase in railroad building had far-reaching effects on the lumber industry of the Upper Middle West. Initially, this expansion meant an unbelievable number of ties, trestles, and buildings. 5 But once

\section{Ibid.}

5The lumber demand of the railroads during the period from 1870 to 1890 is staggering. For example, the lumber consumed just for railroad ties during this period represents a major share of the lumber industry's total output. Figuring railroad ties at two foot intervals, the 113,781 miles of trackage built during this twenty year period represents approximately 300,381,840 ties. Figuring each tie at eight inches by eight inches 
this demand for lumber was satisfied, the equally large lumber requirements for the great increase in railroad rolling stock which followed put continued pressure on the Iumber industry of the Upper Mississippi Valley. Consisting almost entirely of wood above their carriage system, these early railroad cars required lumber not only for framing but also for flooring, siding, roofing, and interior finish. So great was the influence of the railroads on the lumber market that yet today the term "car siding" prevails in the Iumber industry in reference to several patterns of siding even though steel has long since replaced lumber as the siding material for most railroad cars. This great demand for Iumber by the railroad car manufacturers was directly proportional to the great increases in the numbers of railroad cars being built at the turn of the century. Table 5 on the following page clearly shows this increase. Another significant fact which greatly influenced the lumber industry of the Upper Midwest was that some of the nation's major railroad car manufacturers located their plants in cities easily accessible to the lumber which they needed so badly. Chicago and St. Louis quickly became Ieaders in this industry. Chicago's PuIInan Company and the American Car Company of St. Louis by 1880 had become the largest man-

by seven feet, this number would equal approximately $11,114,128,080$ board feet of lumber. In comparison, this amount of footage would build some 733,333 homes, the average home containing approximately 15,000 board feet of lumber!

Some of these ties were produced locally, but the vast majority of them came from the mills in the Upper Midwest and were shipped to other parts of the nation. The coniferous species of the northern states were much more suited to such uses than were the hardwood species of the Midwestern and Middle Atlantic states where railroad growth was most pronounced. The conifers were easy to work, produced Ionger lengths of lumber, held their manufactured shape better when exposed to the clements, and grew in greater volume per tree than the hardwoods. 
ufacturers of railroad cars in the United States. 6 These industrial centers naturally relied on the Iumber industry of the Upper Mississippi Valley as their primary lumber resource.

TABLE 5

INCREASE IN RAIIROAD CARS $1887-19007$

1887 $\underline{1890}$ $\underline{1900}$

Group I

(Ohio, Michigan, Indi-

ana, IlIinois, and

Wisconsin)

Number of:

$\begin{array}{lrrr}\text { Passenger cars } & 4,297 & 4,842 & 6,522 \\ \text { Baggage, Mail, etc. } 1,888 & 1,970 & 2,4,24 \\ \text { Freight } & 291,347 & 325,027 & 432,699\end{array}$

Group II

(Iowa, North Dakota, South Dakota, Minnesota, Montana, Nebraska, and Wyoming)

Number of:

Passenger cars 935

Baggage, Mail, etc. 447 Freight

55,793

1,321

537

77,276

1,626

571

112,752

The Fintire United States

Number of:

$\begin{array}{lrrr}\text { Passenger cars } & 20,582 & 23,083 & 26,786 \\ \text { Baggage, Mail, etc. } 6,592 & 7,368 & 8,209 \\ \text { Freight } & 956,631 & 1,110,286 & 1,350,258\end{array}$

6 Stewart H. Holbrook, The Age of the Moguls (New York: Crown, 1947), pp. $117-18$.

7U.S., Bureau of Statistics, Statistical Abstract of the U.S.: 1901 (Washington: U.S. Government Printing Office, 1902), p.392. Also, see U.S., Bureau of Statistics, Statistical Abstract of the U.S.: 1894 (Washington: U.S. Government Printing Office, 1895), p.307. The amount of lumber used in these cars was overwhelming. The dimensions of a standard freight car of the period were ten feet in height by nine feet in width 
The lumber demands of the nation's railroads at this time in our history more than filled the void created by the decline of the wooden shipbuilding industry. The manufacture of wooden sailing vessels reached its peak in 1855 when a total of 510,690 tons were built. In contrast, by 1889 the production for the industry had dwindled to a meager 71,816 tons. 8

Not only was the demand there, but also the supply or at least the necessary raw material was close at hand. The great white pine forests of northern Wisconsin and northern Minnesota far exceeded the Iumbermen's wildest dreams. However, the lumbermen now began to have certain doubts about their industry in respect to the changing and increasing. demands for their product. True, the industry by 1890 was well estabIished in the Upper Midwest. The concentration of logging operations and samills in the Upper Mississippi Valley by this date rivaled the magnitude of the previous concentrations along the Saginaw or the Penobscot, and it was reasonable to assume that these new lumbering operations could satisfy the great increase in demand. What began to cause concern among various lumbermen was the problem of making the most of the opportunity using the traditional methods of the industry. Sawmills were still independent and generally operated on a relatively

by thirty six feet in length. Eliminating from consideration all lumber used for framing, bracing, and trim, the total footage per car of the two inch lumber used for flooring and the one inch stock used for siding and roofing was approximately 2,000 board feet. The total amount of siding, roofing, and flooring consumed in the 1,350,258. freight cars in existence in 1900 would be approximately 2,700,516,000 board feet of lumber! (Francis E. Lister, The Car Builder's Dictionary (New York: The Railroad Age Gazette, 1909), pp.66-67.)

8U.S., Bureau of Statistics, Statistical Abstract of the U.S.: 1889 (Washington: U.S. Government Printing Office, 1890), pp.206-08. 
small scale. Few, if any, mills owned their own timber, preferring instead to purchase logs from the various independent logging companies. Most recognized the fact that their survival depended upon controlining their log supply, yet few of the Mississippi mill owners had sufficient financial resources to insure an indefinite flow of logs into their mills. Furthermore, mistrust and competition among them was so great that any cooperative effort in respect to acquisition of stumpage or to long term arrangements with the logging contractors seemed remote. As Frederick E. Weyerhaeuser, the son of the man who was to eventually bring order to the confusing situation, observed, "Nany (Iumbermen) of the Mississippi Valley - . were ready to fight one another upon the slightest pretext . . . There was little if any spirit of co-operation." 9

This mistrust and competition was in evidence in other areas of the lumber business. For instance, at the mill level each mill attempted to capture its share of the market by manufacturing Iumber according to its own specifications. The theory was that once a customer started to buy the product of a particular mill, the uniqueness of the sizes, patterns, and grades would insure repeat business. The result was almost complete confusion. The Northwestern Lumberman, a trade journal of the period, noted the "Babelic confusion" which seemed to prevail in lumber manufacturing practices. Concerning the initial attempts to standardize lumber grades throughout the nation's entire lumber industry, it remarked that these rules had been "so kicked, cuffed, knocked, and mutilated that the fond parents of the system (the lumbermen) would

\footnotetext{
$9_{\mathrm{Hidy}}$, Hil], and Nevins, Timber and Men, p.42.
} 
not know their own offspring."10

In wholesaling the products of the mills the story was much the same. Being small and independent placed a definite restriction on the possibility of having compary salesmen traveling the countryside selling to the retail lumber dealers and to the large industrial accounts. Instead, sales efforts were for the most part carried on by expensive, independent wholesale brokers in metropolitan areas, such as Chicago. At best, the sales situation was chaotic.

With this independence, confusion, and extreme competition at all levels. of the industry it was small wonder that only a few lumbermen along the Upper Mississippi were really benefiting to the maximum from the seemingly ideal economic conditions of the time and locale. However, the lumber industry of the period was not alone in being faced with such a predicament. In many industries at this time in our history following the Civil War the same situation existed. Technological advances and market conditions exposed unlimited possibilities, but existing conditions, business structures, and business practices were not such as to take advantage of these opportunities. It was at this moment in the history of the United States that into the center of the economic stage stepped the small group of men who seemed to possess the qualifications needed for leadership in this new era of American business. Gone were the days when the business world was dominated by the single proprietor or the simple partnership. In their places of leadership came the so-called moguls, heading the large corporations whose business outlook and sphere

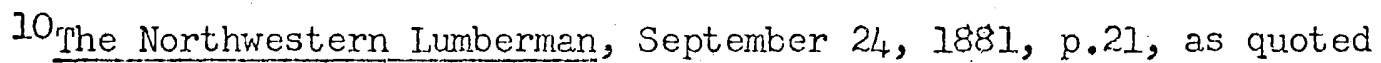
by Hidy, Hill, and Nevins, Timber and Nen, p. 175 . 
of influence were national and often international in scope. Each major industry, whether it were oj.l, railroads, banking, chemicals, mining, or food processing had during the latter half of the nineteenth century certain individuals or small groups of men who were instrumental in the consolidation and expansion of the given industry which eventually placed it in the category of "Big Business."Il Lumber was no exception, for it was at precisely this time that the young German immigrant, Frederick Weyerhaeuser, began to build his vast kingdom. The Weyerhaeuser interests have dominated the lumber scene so much during the last one hundred years that any study of the industry would be incomplete without using Weyerhaeuser and his organization as a primary point of reference.

Of all the great business moguls of the late 1800 's and early 1900 's few, if any, still today carry an air of mystery like that which surrounds the Weyerhaeuser name and fortune. Generally speaking, these men created their empires in full or at least partial view of the pubIic. What they tried to hide from the public more often than not showed up in the form of their ornate homes, their yachts, or other pleasures. Only occasionally during the period of the rise of big business in the United States was a man able to amass a fortune in secrecy. For instance, Holbrook in The Age of the Moguls tells about Andrew Mellon and how he was able to build his fortune practically unnoticed. 12 However, when Mellon became Secretary of the Treasury in the 20's, his background

II Harold U. Faulkner, The Decline of Laissez Faire (New York: Rinehart and Co., 1951), pp. 153-61.

12 Holbrook, The Age of the Moguls, pp. 212-30. 
became general public knowledge. By the 1930's enough had been written about the Rockefellers, the Fords, the Carnegies, the Vanderbilts, and the other giants of American industry so that their names and Iives were known to almost everyone. Not so with Weyerhaeuser. Outside of the lumber industry few people could pronounce his name, let alone spell. it. He was virtually unknown, and yet in 1907 there appeared, to the surprise of the general public, a magazine article proclaiming Frederick Weyerhaeuser to be richer than even the acknowledged king of wealth, John D. Rockefeller. 13

- Until 1963 there was little published material available concerning the history of Weyerhaeuser and the growth of his lumber empire. Nany of the standard books written on the early industrial leaders of America, fail to even mention Weyerhaeuser's name, and those that do mention it only in passing and in a very superficial manner. Holbrook in The Age of the Moguls says nothing of the Weyerhaeuser interests. Josephson also fails to make note of weyerhaeuser in his book, The Robber Barons. 14 Myers in his History of the Great American Fortures devotes only four pages to Weyerhaeuser, and this only because of the connection between Weyerhaeuser and James Hill's Northein Pacific Railroad. ${ }^{15}$ It was not until late in the 1950's that certain officials of

${ }^{13}$ C.P. Norcross, "Richer Than Rockefeller - Weyerhaeuser", Cosmo-" politan, January, 1907, as quoted by Roy E. Appleman, "Timber Empire From the Public Domain", Mississippi Valley Historical Review, September 1939, XXVI, No. 2, p. 208. 1934).

I4Mathew Josephson, The Robber Barons (New York: Harcourt Brace \& Co.,

15Gustavus Myers, History of the Great American Fortunes (New York: Randorn House, Inc., 1936), pp. 689-92. 
the Weyerhaeuser organization proposed that the complete history of the Company be written. The result of this proposal was published in 1963 under the title of Timber and Men: The Weyerhaeuser Story. Its co-authors are Ralph Hidy, Frank Hill, and Allen Nevins. These men have done exhaustive research of their subject, and yet even this work leaves several important questions unanswered. Although in the introduction of the book the authors claim "absolute independence" and complete freedom of thought and although Weyerhaeuser Company officials deny any company subsidy for the study, it is obvious after reading the book and in drawing upon personal knowledge of the Weyerhaeuser history that the book does reflect a very favorable attitude toward the company and its early policies, and at several points in the book the authors fail to present the complete story of important events in the firm's history. The complete understanding of some of these events, such as the acquisition of timberlands from the railroads, is most important to the understanding of the development of the entire lumber industry, particularly in the Pacific Northwest. Much of the information for this book was gathered from direct conversations with present Weyerhaeuser officials and family members, and, as the authors admit in their acknowledgments, F.K. Weyerhaeuser, who was chairman of Weyerhaeuser's board of directors at the time the book was published, even helped in proof reading the final work. For these reasons one can not place complete reliance in some of the material presented in Timber and Men but must look elsewhere to find the complete story. Nevertheless, Timber and Yien is a long overdue account of the Weyerhaeuser empire and its role in the development of the lumber industry. Along with company 
publications it is a valuable source of information for a study of the Weyerhaeuser organization as it reflected the development of the entire lumber industry during the past one hundred years.

The significance of Weyerhaeuser is that he became the main force behind the consolidation and coordination of the early lumber interests in the Upper Mississippi River Valley and later in the Pacific Northwest. His early history is one of steady progression to a position of wealth and influence. He came to the United States from his native Germany in 1852 at the age of seventeen, and after a series of jobs and moves he eventually settled in Rock Island, Illinois, which at that time was a center of lumber manufacturing on the Mississippi. He worked at the Mead, Smith, and Marsh sawmill in Rock Island for a time as a general laborer and then advanced to the position of manager of one of the firm's retail lumber yards. The sawmill went bankrupt in the Panic of 1857, however, Weyerhaeuser had demonstrated his managerial abilities to such an extent that the creditors decicied to allow him to continue operation of the retail yard. Although he was only twenty-two at this time and had worked for Mead, Smith, and Marsh for only a year and a half before the firm went bankrupt, Weyerhaeuser showed his full managerial abilities in his new position for even though money was scarce he was able to build his credit through the simple yet sometimes complicated process of barter. He soon was able to purchase the retail lumber yard himself, and in 1860 Weyerhaeuser and his brother-in-law, F.C.A. Denkmann, formed a partnership and purchased the sawmill itself along with other assets of the former lumber firm. During the next few years Weyerhaeuser and Denknann Company pros- 
pered to the extent that Weyerhaeuser was able to expand his horizons by an initial purchase of 840 acres of timber along Wisconsin's Chippewa River on December 14, 1870.16 In his trips up and down the Mississippi and into the logging regions of Wisconsin he came into contact with the leaders of the various segements of the industry. His trips and experiences also exposed him to all of the wasteful methods and to all of the ruthless and sometimes shady practices which individual operators were resorting to in order to make a showing. Weyerhaeuser reasoned that if the leading men of the Upper Mississippi Valley lumber industry could somehow unite and reconcile their differences and conflicting interests, all would benefit. Others had attempted such cooperative ventures in the past but had failed, but Weyerhaeuser felt that the time was ripe for another attempt at organization.

One such area of conflict was centered around the right to drive logs on the Chippewa River in Wisconsin. Since most of the local mill owners in and around the towns of Eau Claire and Chippewa Falls had their own logging crews in the woods, the independent logging firms located in the forests of the Chippewa River basin had to sell their cut primarily to the mills below Eau Claire, particularly to those located on the Mississippi River. The mill owners of Eau Claire and Chippewa Falls resented and resisted this attempt of their competition to drive the Chippewa. Their objections were based prinarily on the reasoning that these drives were creating obstacles and hazards to the local mill operations. Occasional log jams and broken log booms caused by run away logs were given as evidence of this danger. Also, the lumbermen of the 
Upper Chippewa argued that only finished goods should be allowed to leave the state. The log drives of the Mississippi mills would strip Wisconsin of her raw materials, and in doing so the economy of the state would suffer accordingly. Because of these objections the local mill owners constantly harassed the log drives of their down-river competitors by blockading the river and diverting the logs into their own booms, thus delaying the drive and imposing additional hardships on the Mississippi mills, which were eagerly awaiting their logs. 17

To solve the blockades imposed by the Upper Chippewa lumbermen, a group of the independent timber owners and logging concerns organized in 1867 the Beef Slough Manufacturing, Booming, Log Driving, and Transportation Company. Its purpose was to facilitate the driving of logs. past Chippewa Falls and Eau Claire into the Beef Slough at the mouth of the Chippewa River. Once in the boom works constructed in the Slough the logs could then be rafted for the journey down the Mississippi.

However, the Upper Chippewa mill owners by legal action and by outright physical action continued to be successful in their efforts to stop the Beef Slough Company from completing their drives. In regard to the legal aspect, the Chippewa Falls-Eau Claire grour was able to bring sufficient Iobbying pressure to bear upon the Wisconsin legislature, which had the power to grant the concession to navigate the state's rivers, and the awarding of the concession on the Chippeva River was delayed Iong enough to insure bankruptcy for the new concern.

To augment their efforts at the legislature, the mill owners con-

I7 Robert F. Fries, "The Mississippi River Logging Co. and the Struggle for the Free Navigation of Logs", Mississippi Valley Historical Review, Decemioer 1948, XXXV, No. 3, p.430. 
tinued their direct delaying tactics. Each spring brought a new drive and a new battle to see if the logs would pass Eau Claire or would pause for a month or Ionger in their journey down to the Mississippi. The lumbermen of the Upper Chippewa gained their biggest physical victory in the spring of 1868 when they successfully diverted and held in their booms through June the entire drive for which the Beef Slough Company had contracted. This amounted to approximately 50 million board feet of logs. ${ }^{18}$ As a result of these delaying tactics the Beef Slough firm was on the verge of bankruptcy by 1870 .

The impending failure of this concern meant that the Mississippi mill owners, none of whom had been involved in the Beef Slough Company, would be cut off from their most promising supply of logs. By 1870 the timber in the Chippewa basin held the key to the continued prosperity of the Mississippi sammills, for by this time the timber reserves of Wisconsin's other river basins, primarily the Wisconsin River and the Black River, were claimed and fairly well logged over. Not so with the Chippewa. There was plenty of choice timber either unclaimed or in the hands of holders who were willing to sell the stumpage at the right price. Cornell University, for instance, by 1867 owned 499,126 acres of prime timberland along the Chippewa. 19 If the Mississippi mill owners could find a solution to the Chippewa blockade, they could have access to this timber. However, few of them were willing to take the steps and the risks to alleviate the problem, feeling that the investment was too great for any individual mill to handle. Weyerhaeuser thought differently, and

\footnotetext{
${ }^{18}$ Ibid., pp. $431-34$.

19 Hidy, Hịll, and Nevins, Timber and Men, p. 43.
} 
in association with Lorenzo Schricker and Elijah Swift, who were also lumbermen operating along the Mississippi, he leased the nearly bankrupt Beef Slough Company on November 1, 1870. This venture was followed by the formulation of the Mississippi Logging Company in December of the same year. ${ }^{20}$ This latter firm included other mill owners along the Mississippi, and by pooling their financial resources in a cooperative effort, they were able, after a long legal battle, to gain the right to drive the Chippewa. Of even greater significance was the fact that these two concerns were the beginnings of the giant Weyerhaeuser syndicate which by 1900 ruled the nation's softwood lumber industry from coast to coast.

The members of these original Weyerhaeuser organizations soon found that their personal fortunes were greatly increased by the pooling of their individual resources, abilities, and interests. To begin with, waste in the form of unprofitable logging practices could now be eliminated. Formerly, the patchwork nature of timberland ownership had made logging difficult if not at times almost impossible. With different sections of land owned by different owners the loggers had to respect property rights which often hindered their production. inen the necessary right-of-ways were refused, the loggers had to restrict their logging to available tracts of timber, which might be widely separated. By joining either or both of the two boom companies, the Mississippi lumbermen and the logging concerns in the Wisconsin woods eliminated this problem. All timberland along the Upper Chippewa and its tributaries owned by the members of the syndicate became common property, at 
least for the sake of logging. The loggers thus could log this common property without respect to property rights. The result was greater production at less expense. Timber was cut and all logs were sent down the Chippewa to Beef Slough. It was here, not in the woods, that the logs were sorted and graded. When this was done, the logs were divided according to species, size, and grade by pre-arranged percentages. They were then rafted, and the rafts towed down the Nississippi to their respective owmers. The significance of this arrangement was that it relieved the mill owners of worry over their log supply. Logs now would come to the mills in a constant and definite flow, and each mill could concentrate all of its efforts on processing the logs.

During the entire period of growth in the Viisconsin area, Frederick. Weyerhaeuser was the "driving spirit" behind the Mississippi lumbermen. Although the struggle over river rights on the Chippewa was to continue until 1881, the associations begun primarily through Weyerhaeuser's efforts in 1870 and which eventually encompassed three quarters of the sawmilling investments between Winona, Minnesota and St. Louis, Missouri, soon began to show the necessary cohesiveness and unity of purpose needed to insure an ultimate victory for the Mississippi mill owners.2l By 1873 Weyerhaeuser had fourteen associates united with him to fight the battle 6 of the Chippewa. All of these men and the firms they represented remained as individual units, surrendering only that portion of their sovereignty which was required by the new corporation. "The company (Nississippi River Logging Company) combined cooperation with pungent individualism. No firm surrendered one iota of control over 
its manufacturing or sales. Yet with a common objective, and under the leadership of Frederick. Weyerhaeuser, they became an effective team for buying, driving, and sorting logs."22 Entering into the association strictly to protect their individual business interests, the Mussers, the Lambs, the Lairds, the Nortons, the Weyerhaeusers, and the others in time found friendships growing and eventually replacing former feelings of mistrust. Later generations of these families were to intermarry, cementing the bonds even more permanently. 23

During this entire period of growth in the Wisconsin area, Weyerhaeuser was the guiding force, but still he manipulated his business ventures without publicity or public awareness. In 1891 he moved his residence from Rock Is land to St. Paul, Minnesota and thus entered into another phase of his career. By this time the center of the lumber industry had shifted from Wisconsin to Minnesota with the major concentration being in the cloquet area. Once again the story was the same. Minnesota became in time a repetition of the earlier success of Weyerhaeuser in Illinois and Wisconsin. By buying up tracts of virgin white pine timberlands, by gaining control of manufacturing operations around the major lumber centers such as Cloquet and Stillwater, and by further consolidation of their interests the Weyerhaeuser group grew rapidly. In the region north of Minneapolis and St. Paul the evergreen

22Hidy, Hill, and Nevins, Timber and Men, p. 53.

23 Even today these early associations are evident in the names of many current Weyerhaeuser Company officials. Probably the best and most obvious example is that of Norton Clapp, until recently the president of the company. Mr. Clapp can trace his origins back to Mathew G. Norton, one of the original Mississippi River Logging Company partners, and to N.H. Clapp, the legal advisor to and an eventual partner in the early Weyerhaeuser operations (Hidy, Hill, and Nevins, Timber and Men, p. 328). 
forests covered a greater area than had those of Wisconsin before they had been depleted by the lumbermen. Weyerhaeuser made his initial venture into this area in 1890 when he and others of his associates formed the Pine Tree Lumber Company and purchased 212,722 acres of timberland on the Upper Viississippi watershed from the Northern Pacific Railroad for $\$ 452,330 .^{2 / 4}$ This was part of the land grant given to the Northern Pacific, and it represented the first of several large timberland transactions between the railroad and the Weyerhaeuser syndicate.

With the incorporation of the Pine Tree Lumber Company and its initial timberland purchase, Weyerhaeuser embarked upon the first phase of a two part exploitation of Minnesota's forests. Locating the manufacturing facilities of Pine Tree at the town of Little Falls, Minnesota, they were able to take advantage of the excellent transportation possibilities afforded by the Mississippi River not only in bring logs to the mill but in shipping the finished lumber downriver to Minneapolis and St. Paul. Prospects were encouraging enough to warrant the crea-tion of another corporation in 1893. The Mississjppi River Lumber Company was established with the intention of setting up a second manufacturing unit to process the timber of the Upper Mississippi watershed. However, due to the general economic depression which developed in 1893, this plan never materialized, and the Mississippi River Lumber Company spent its entire existence as a timber and logging company, acquiring timberland, logging the timber, and selling the logs to the Pine Tree Lumber Company and also later to the Northland Pine Company, the final member of the Weyerhaeuser triumvirate in central Ninnesota. Northland Pine, incor- 
porated in 1899, with milling facilities located in Minneapolis, in reality was the manufacturing unit intended to be integrated with the Mississippi River Lumber Company.

None of these three ventures was to last. Pine Tree Lumber Company had by far the longest life, ending its lumber production and shipment in 1920, thirty years after its creation. Northland Pine likewise closed its mill in 1920, being the last Minneapolis mill to shut down, thus signaling an end to a distinct period of that city's development. However, within the relatively short span of existence of all three companies Weyerhaeuser and his associates were quite handsomely rewarded. According to Timber and Nien,

The three Weyerhaeuser lumber companies operating in central Ninnesota had all been successful in carrying through their undertakings, and all profited on a more than generous scale. By 1922 Pine Tree, which almost twenty years earlier had paid all its deots and returned 100 percent on the original invested capital, had paid its stock holders an additional $\$ 11,463,395$. Up to 1910 the Mississippi River Lumber Co. paid no dividends, but during the next eight years distributed $\$ 3,958,750$ - more than twice the original investment. Northland declared dividends totaling almost $\$ 1,000,000$ by 1903, and between 1908 and 1925 paid out $\$ 6,900,000$ more, largely reflected in the earning statements of its two parent corporations.25

The other main Minnesota venture of Weyerhaeuser was even more successful and more significant. By 1890 the forests bordering Lake Superior and those within the watershed of the St. Louis River represented over half of the remaining white pine timber in Ninnesota. Weyerhaeuser realized that the region held great potential, and although at the time he was deeply involved in pursuing his interests in central Minnesota, he seized several opportunities to become involved in the growing lumber industry in the northeastern corner of the state. 
His first opportunity came in 1883-84. The Knife Falls Lumber Company of Cloquet was experiencing financial difficulty and was forced to dispose of its holdings. Weyerhaeuser became involved when he loaned the organization $\$ 25,000$. To protect his money, he eventually was able to instigate the sale of the concern to a group of Davenport, Iowa, lumbermen led by George S. Shaw. In 1884 a new corporation was formed under the name of Renwick, Shaw, and Crosett Company, and the sale was consummated. For his troubles and for his $\$ 25,000$ loan Weyerhaeuser and his brother-in-law, F.C.A. Denkmann, received 250 shares of stock, which was approximately fifteen percent of the total number of shares distributed. 26 This was the start of the reign of Weyerhaeuser over the Cloquet lumbering scene, a reign which in a few short years would control all major processing units in the town and dominate almost completely the Cloquet economy.

The Renwick, Shaw, and Crosett Company became the Cloquet Lumber Company in 1886 and by 1889 it was firmly established as one of the region's major lumbering concerns. Although George Shaw remained the principal stockholder, Frederick Weyerhaeuser's influence in the company grew rapidly. In 1885 he was selected vice president of the firm and held this office until 1897 when he became president. During this period the company's success was reflected both in the profit it made for its owners and in the growth of the company's physical plant. Cloquet Lumber Company began almost immediately to pay handsome dividends to the stockholders, including eight percent payments in both 1886 and in 1890. These, coupled with several stcck dividends, greatly enhanced the

26 Ibid., p. 117 
wealth of the principals. As for the physical property of the concern, its continued growth led to the purchase of an additional mill site in 1889, and by 1892 the capitalization of the firm had reached $\$ 1,000,000$, more than three times the original amount. 27

Weyerhaeuser and his associates launched their second Cloquet venture in 1895. Learning of the availability of the C.N. Nelson Lumber Company, Weyerhaeuser persuaded the Cloquet Lumber Company and several of his earlier associates from the Mississippi River Logging Company era to join with him in the formation of a new company for the purpose of buying out Nelson. The resulting Northern Lumber Company bought the C.N. Nelson properties for $\$ 1,900,000$. Included in the purchase were two mills located at Cloquet and some $600,000,000$ feet of pine timber. ${ }^{28}$ The significance of this purchase and of the creation of Northern Lumber Company is twofold. First, it at least doubled Weyerhaeuser's control over the Cloquet scene. Of the five major mills operating in the area, two were controlled by Cloquet Lumber Company and now two more were owned by Northern Lumber Company. All that remained was the mill of the Johnson-Wentworth Company. which in time would also come into the Weyerhaeuser camp. Secondly, it marked the emergence of Rudolph Weyerhaeuser, Frederick's third son, into the world of business management. Just twenty seven years old, Rudolph was sent by his father to manage the new operations in Cloquet. Like his older brothers, Rudolph was given a position of great responsibility early in his career, and he responded to the challenge in such a manner that the elder Weyer-

$$
\begin{aligned}
& 27 \text { Ibid., p. } 118 . \\
& 28 \text { Ibid., p. } 119 .
\end{aligned}
$$


haeuser could soon relax his own efforts in northeastern Minnesota and concentrate on new areas of interest. Rudolph's grasp of the business was so complete that within a few years after coming to cloquet he was in fact if not in name the key figure in the Weyerhaeuser group which ruled Cloquet. Finally, in 1902 the domination of Cloquet by the Weyerhaeuser syndicate was completed with the purchase of the Johnson-Wentworth Company, the last remaining independent operator on the Cloquet scene, for $\$ 2,535,622.29$

The cycle was now complete. The weyerhaeusers now controlled the five large mills in Cloquet, and this control gave them unprecedented power in the north woods. The union of the major milling facilities gave these men vast buying powers, particularly in regard to timber land. Purchases could now be made jointly, and much larger tracts involving great sums of capital could be considered. The independents in the area found themselves unable to handle such large transactions, and as a result the Weyerhaeusers in many instances were able to drive their own bargins. Probably the best single purchase in terms of timber acquired for cash spent was a sale by the Northern Pacific Railroad to the Northern Iumber Company in 1900 of 31,348 acres containing an estinated 235,000,000 feet of choice pine timber. The sale price was $\$ 686,586$. This amounted to approximately $\$ 22$ an acre. The largest transaction in terms of total volume of timber came in 1905 when joint purchases for the Cloquet mills totalling 550,000,000 feet of timber were made for a price of $\$ 3,360,000$. This timber was acquired from a variety of owners, including speculators, the railroads, the state, and 
other lumber companies. By 1908 the advantage of these joint efforts in the purchasing of timber was most evident for by this date the three Weyerhaeuser firms in Cloquet held approximately 1,500,000,000 feet of standing timber. 30

Thus, with the completion of their Cloquet kingdom this small group of men under the expert guidance of Frederick Weyerhaeuser had reached the pinnacle of their success in midwestern lumbering. Weyerhaeuser had quickly emerged as the main force behind this success, many times exhibiting the needed foresight and raw business courage to forge ahead in the face of great risks while his competitor's and even his associates preferred to move with greater caution. In assessing this period of Minnesota's history, Timber and Men states that

By the late 1890's Weyerhaeuser had taken a tripartite role in opening the hinterlands of Minnesota. Through Pine Tree and Mississippi River Lumber he and his associates controlled an immense stumpage in the Upper Mississippi area, while through Cloquet and Northern they held an even larger amount of pineland on the St. Louis watershed. They already owned considerable timber in the pine area lying still farther north. Through Mississippi River Lumber and Northern Lumber they owned boom facilities in the two great hinterland territories. Through Pine Tree, Cloquet, and Northern they had opened up the Upper Mississippi and Cloquet districts. Finally: Weyerhaeuser had found roles in Minnesota for three of his sons. As much as any one man can be said to have expedited modern lumbering in the remoter reaches of the state, he can be singled out as having done so.3I

30 Ibid., p. 191.

3I Ibid., p. 120. The three sons were Rudolph and his younger brother, Frederick E. Weyerhaeuser, who went to work in the Cloquet area; and Charles A. Weyerhaeuser, an older brother, who was placed in charge of the Pine Tree operation. The eldest brother, John Philip Weyerhaeuser, had his business initiation in the Wisconsin operations. As will be pointed out later, the aptitude and interest of all of his sons in Frederick Weyerhaeuser's business was no small factor in the success of the organization and in its perpetuation. 
Although there is little doubt that Weyerhaeuser deserves such tribute, one must in retrospect also take into consideration the means by which he attain these successes. Also, the long term effects and consequences of some of these successes tend to show these achievements in a somewhat difierent perspective. The authors of Timber and Men tend to gloss over certain aspects of the practices of the ireyerhaeuser group, which definitely need a closer study if the complete story is to be told. 32 To say that their business practices were always one hundred percent ethical would be stretching the imagination. 33

Among the more prevalent business practices employed by the early Iumbermen were such questionable tactics as the use of the durmy entrymen, cutting "around forty", and the denial of access or right-of-way to a competitor. Stemning from the rather inept federal land acts of the late 1880's and the subsequent laxity of their enforcement, the use of dummy entrymen and cutting "around forty" were common means by which

${ }^{32}$ In reading Timber and Nen the favorable attitude towerd Weyerhaeuser show by the authors is consistent with the observation made by Ray Ginger in commenting on the bias style of writing offered by Hidy and Nevins in some of their other books. In evaluating the resources used for his book, The Age of Excess (New..York: Macmillan, 1965, pp. 33031.), Ginger states that "Allen. Nevins, Study in Power: John D. Rockefeller, Industrialist and Philanthropist (1953); and Ralph W. Hidy and Muriel E. Hidy, Fioneering in Big Business 1882-1911: History of Standard Oil Company (New Jersey). (1955), are based on wide ranging research in primary sources. But both of these works seems to me to come to one-sided, overly favorable conclusions becauses of their selective reporting of data."

33 Timber and Men constantly implies such a white wash of the activities of the Weyerhaeuser group. For example, in commenting on the practice of acquiring land through the use of the dummy entry, the authors state that "diligent search has failed to show even one example of the use of dummy entrymer on public lands for the benefit of Weyerhaeuser or his associates. Again and again offers of false entry were made to these firms; they were always rejected." (Hidy, Hill, and Nevins, Timber and lien, pp. 133-34.) 
the wealthier lumber firms and land speculators added to their timber holdings. The practice of the dummy entrymen was used when the federal government would open certain tracts of public land containing valuable timber for sale to the general public. As the terms of such sales generally required permanent settlement on the land, the lumber companies were not permitted to take part. They overcame this obstacle by having agents or trusted employees claim acreage in their own names only to resell it to the lumber firms at or near the original government sale price of $\$ 1.25$ per acre. These people, owners in name only, hence became dummy entrymen. The Timber and Stone Act of 1878 was the best example of the government's generosity in respect to the acquisition of land titles. On the strength of this law "thousands of men were sent into the forests . . to file on timber claims, and in nearly every instance, the entrymen had contracted in advance to transfer their titles to some lumber company. 134 Although the use of the dummy entry was standard practice, particularly among the larger firms, it was next to impossible to put a stop to the illegal procedure. According to Stephen Puter,

There was considerable talk of indictments by the Federal grand jury, and it had a tendency to make the (illegal) land business unpopular for the time being . . . However, in spite of all the storm of indignation that seemed to have pervaded the Government atmosphere, there were comparatively few actual cancellations, the special agents (of the Government), as usual, standing in with the land grabbers.

Thousands upon thousands of acres . . . were secured . . . and nearly all of these claims, to my (Puter's) certain knowledge, were fraudulently obtained. 35

34Stephen A. Puter, Looters of the Public Domain (Portland: Portland Printing House, 1908), p. 21.

35 Ibid., p. 22 . 
The cutting of "around forty" involved an equally loose interpretation of the existing land laws and the terms of sale set forth by the federal land office. The lumbermen, taking advantage of the situation, would often buy from the state or federal government forty acres of timber, which was the smallest unit in which timberland ordinarily changed hands. They would then send their loggers into cut the timber, telling the foreman to log "around (approximately) forty acres." The loggers would then proceed to cut around the original forty acres. "First the forty acres to the north, then to the east, the south, the west. It was thought a neat play on words, and it tickled everyone, except the harassed timber agents of the state and local governments." 36 If and when this illegal practice was detected, the punishment hardly deterred further infractions. The law read that the trespasser should pay the land's "estimated value, in any case not less than \$1.25 per acre." As with the practice of using the dummy entryman, Weyerhaeuser and the other lumbermen of the period were for the most part able to hide their illegal operations extremely well. If caught, it was a small matter to pay the $\$ 1.25$ per acre penalty.

Once the larger firms gained control over large amounts of land they could actually dictate the amount of Iumbering activity within the given region merely by regulating their competition's entry to its lands. The various Weyerhaeuser firms both in the Upper Midwest and later in the Pacific Northwest became in time one of the better exponents of this questionable tactic of the denial of access. It was common for the Weyerhaeuser firms to charge a competing lumber company as much or more

36 Holbrook, Holy old Mackinaw, p. 93. 
than the land itself was worth for the right to cross Weyerhaeuser land to get to their (the competing firm's) timberland. More often than not the competition had no recourse but to sell their land to Weyerhaeuser at the latter's price. ${ }^{37}$ It was chiefly through the ruthless use of this practice that the Weyerhaeuser Timber Company was to slowly but surely cut off the timber supply of the Long-Bell Lumber Company, thus eliminating one of their major competitors in the Pacific Northwest. 38

However, in defense of Weyerhaeuser and his contemporaries it must. be said that their methods of operation, while questionable by today's standards, were generally compatible with the spirit of their times. It is probably safe to say that in keeping with the philosophy of economic Darwinism which prevailed during the pre-1900 period and during the first few years of this century and which dictated that only the strongest and most resourceful will become wealthy, Weyerhaeuser and his group were no more unethical in their business dealings than were many other businessmen or concerns of the time regardless of the industry in which they were engaged. In the business arena where it was a case of survival of the fittest, those who emerged on top, although often accused of using illegal means, were nevertheless held in great awe and respect for the ends which they had attained.

In his battles Weyerhaeuser was the all-conquering victor. His power is vividly shown in the reminiscences of two men who had the opportunity to personally observe the deeds of Frederick Weyerhaeuser, his

37U.S., Department of Commerce, The Iumber Industry (Washington: U.S. Government Printing of $\mathrm{f}^{\prime} \mathrm{ice}, 1914$ ), II, p. $1 I_{4}$

38 Hidy, Hill, and Nevins, Timber and Men, pp. 278-79. Also, see J.M. McClellan, Jr., Longview, The Planned City (Portland: Binford, 1947), p. 153. 
sons, and their business partners. One of these men, Albert Erickson, was a former employee of the Weyerhaeuser organization in northern Minnesota at the turn of the century. $39 \mathrm{Mr}$. Erickson had worked as a laborer in Weyerhaeuser's Northern Lumber Company mill at Cloquet during the first two decades of this century. Although flavored with occasional personal bias, the descriptions of the Cloquet operations by Mr. Erickson were of great interest. As has been pointed out, by 1900 the Weyerhaeuser group was the dominant force in the area, and Weyerhaeuser's two youngest sons, particularly Rudolph Weyerhaeuser, were among the leaders of this group. Mr. Erickson depicted Rudolph and his cohorts as being extremely ruthless men, geared to milk the top dollar from their holdings, while at the same time almost completely ignoring the plight of the woods and mill workers. Many times Mr. Erickson claimed to have seen Rudolph Weyerhaeuser walk through the mill, much like a king surveying his domain, ordering his subordinates to press the men and machines for more and more production. Unskilled labor in the Cloquet region was completely at the mercy of management, for it had no alternative occupations to use as bargining power in any confrontation with management. The situation was the same as it had been in almost every preceding lumbering area. The operators had an ideal situation in which a captive, unskilled labor force without effective leadership or organization and isolated from job opportunities in other fields was theirs to manipulate to the best of their advantage. The labor force was the most variable

${ }^{39}$ Interviews with Albert Erickson between January, 3.959 and August, 1960, St. Peter, Minnesota. At the time I met Mr. Erickson, he was eighty years old and still actively operating his own small retail lumber yard in St. Peter. 
factor of production. According to Mr. Erickson, the Weyerhaeuser organization made the most of the situation. The hours were Iong, the working conditions deplorable with safety guards and safety practices almost non-existent, and the wages were at the minimum level.

Also, at times the Weyerhaeusers, in Mr. Erickson's words, were nothing more than "criminals" in their exploitation of the land for their personal gain. He traced the disastrous and tragic Cloquet Burn of 1918 directly to the exploitation of the forests by the Cloquet lumbermen. As a result of this fire the town of Cloquet was virtually wiped out. The fire completely destroyed two of the five sawmills and the planing mills, storage sheds, and other out-buildings of all five sawmills. Most of the houses in the area were also destroyed. The only structures left standing after the fire were three sawmills, a paper mill owned by Weyerhaeuser, a few homes, and the seventeen "recreation establishments" which had been built on Dunlop Island in the middle of the St: Louis River. In addition to this material Ioss, some 538 people are known to have lost their lives during the blaze. ${ }^{40}$ Although no definite blame has ever been established for the Cloquet fire which consumed approximately 1,500 square miles, Mr. Erickson claimed that much of the blame belongs to the lumber companies of Cloquet. In his opinion, the operators had greedily cut the trees for the sole purpose of making a large profit, and little thought had been given to sound conservation. No fire precautions had been taken in the woods. Much slash was left to lie in the logged over areas. That slash which was p. 37 .

40 Stewart H. Holbrook, Burning An Empire (New York: ViacMilian, 1952), 
piled and burned was often burned indiscriminately with little thought to the possible consequences. Mr. Erickson also claimed that there were no fire roads or breaks, and little firefighting equipment was available. Sound conservation practices were no more of a reality than they had been in the Bangor and Saginaw eras. Conservation, fire prevention and control, and reforestation all meant extra expense which could not be tolerated by the operators if the high short term profits were to be maintained.

However, it was interesting to note that in his denunciation of "Big Lumber", Mr. Erickson was certainly not bitter. 41 As he explained it, this was just the way things were done in those days. Those with money had the power to do pretty much as they wished, and in Cloquet at least there was no great desire to change or condemn this system. In much agreement with the observations of Albert Erickson was Sanford Delyea, a contemporary of Erickson's, who got his start in the lumber business with Weyerhaeuser's cloquet Lumber Company at the turn of the century. 42 Delyea also told of how the Weyerhaeuser group drove

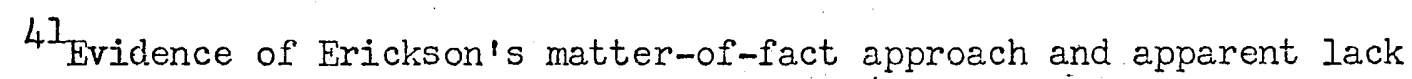
of personal bitterness was quite obvious in 1960. In spite of all his experiences, he still demanded nothing but weyerhaeuser lumber products in his retail yard, thus revealing that he was rather proud of his association with history.

42 Interviews with Sanford Delyea between January, 1959 and August, 1960, Mankato, Minnesota. When Delyea retired from Weyerhaeuser in 1955, he had accumulated some fifty years with the organization, having started work for the company as a boy of fifteen in Cloquet. Later moving on to the Pacific Northwest, he eventually worked into the lower ranks of management, finally ending his career as a salesman for Weyerhaeuser in southwestern Minnesota.

The Delyea family had quite a reputation in logging circles. Sanford and his brother, Bill Delyea, were well known for their abilities in the sport of log birling. Bill was at one time considered the world champion of this rugger sport (Holbrook, Holy Old Mackinaw, pp. 128-29). 
toward complete domination of the Cloquet scene. Built entirely on sawdust, the town hummed with excitment both day and night. During the day the mills throbbed with activity, and at night as the mill refuse burners illuminated the area, the mill hands and those loggers who were in town carried on a rough and ready social life, concentrating their after-hours efforts on the seventeen saloons and/or fancy houses nestled on Dunlop's Island. According to Mir. Delyea, when the annual spring log drive was safely in the booms, the commotion in Cloquet was equal to the combined effects of "circus day, Christmas, and a Polish wedding reception".

In spite of the occasional revelry, all was certainly not fun. The men of Cloquet faced constant danger, both in the woods and in the mills. Delyea's description of these operations was much the same as that of Albert Erickson. Production was the sole goal of the lumbermen. The mill hands were goaded on with little heed for personal safety. As one author has aptly described the prevailing attitude of the early lumber operators, they looked upon themselves as being

- - rugged individualists of the old stamp, many of whom had risen to positions of leadership form the lowest rungs of the industry by exercising the virtues of perseverance, frugality, and initiative. They quite understandably accepted the prevailing philosonhy of business success as the attainable end of exercising such virtue, and they tended to project their attitudes into their labor force, expecting them to take conditions as they came or to rise above the conditions in the only acceptable manner! They treated their employees in a rather ruthless manner, hiring masses of men when the market was favorable and pressing them to great production through long hours of work and then firing men wholesale when the lumber market fel]. There was no hint in their behavior that they felt that mutual obligation between employer and employee was a desirable goal in the industry. 43

43 Robert I. Tyler, "The Loyal Legion of Loggers and Lumbermen" (Unpublished seminar paper, Oregon Historical Society Collection, Portland, 1951), p. I. 
The workers in the mills responded because they knew no other alternative. Many were ex-loggers who not only knew how to work but actually enjoyed it and took great pride in their efforts. In the woods the typical Iogger was expected to remain in the forest for months on end, working in sub-freezing weather from before sun rise until after darkness had set in in the evening. He was expected to live in Spartanlike camps which were at best bleak outposts in the wilderness whose living conditions were generally substandard. If a man could not make the grade as a "timber beast", he didn't hang around camp long, for the camp foreman always had a new recruit ready to take over.

In cormenting on his own experiences as a logger for the Cloquet Lumber Company, Mr. Delyea said that it was a common practice among all of the logging outfits, including those of the Weyerhaeuser firms, to occasionally indulge in such questionable logging methods as "cutting around forty" and jumping survey lines. Thether done intentionally or unintentionally there was always the ready-made excuse that deep in the forest it was impossible at times to get true bearings. As Sanford related it, such practices were used by all of the operators as a natural or "legal" method in their intense struggle to survive.

It is interesting to note that this is much the same reaction as that of $\mathrm{Vr}$. Erickson. Although admitting that there was room for some doubt about certain practices of the Weyerhaeuser group, particularly during these early years, Sanford Delyea was always quick to assert that in his estimation the conditions of this period made these methods necessary. Apparently, the successful man of the late 1800 's and early 1900's was the envy of almost everyone, even though he may not have had the respect of all. Even a certain amount of ruthlessness was accepted 
as necessary to achieve the end goal of wealth. The greater one's fortune, the greater the awe in which he was held by his contemporaries. Weyerhaeuser was no exception, at least among the Iumbermen of the northwoods. 44

This was the nature of the man whose personal fortune at the time of his death in 1914 rivaled and perhaps even surpassed all of the other industrial giants of his time. 45 By the time Weyerhaeuser moved to St. Paul in 1891, he was rapidly becoming the recognized ruler of the economy of the Upper Midwest, even though the major part of his vast wealth was still to come. One author has estimated that at the height of their power in the Middle West the Weyerhaeuser combine controlled approximately 10,000,000 acres of timber. 46 However, through lack of conservation and the disastrous forest fires, particularly the Hinckley Burn of 1894 and the Cloquet Burn of 1918, these stands of virgin timber

$44 \mathrm{To} \mathrm{Mr}$. Delyea, Weyerhaeuser was a way of life, and he never seemed to tire of retelling of the event which made the most lasting impression on him during his own exciting life as a lumberman. It happened long ago when Sanford was still in his teens, working on the mill pond at the Cloquet Lumber Company. After performing a difficult and dangerous maneuver on the logs, he was rewarded for his efforts with a handshake and a word of praise from "the original Mr. Weyerhaeuser." When Sanford told this story, it was almost magical to see the feeling of pride and reverence which would come over him.

45 There seems to be no clear estimate of Frederick Weyerhaeuser's personal fortune at the time of his death. Myers in History of the Great American Fortunes claims it was $1300,000,000$, or thereabouts." Roy E. Appleman in his article says that the figure ranged from $\$ 300,000,000$ to $\$ 600,000,000$ ("Timber Empire From the Public Domain", Mississippi Valley Historical Review, September, 1939, XXVI, No. 2). C.P. Norcross in his article, "Richer Than Rockefeller - Weyerhaeuser", estimated the Weyerhaeuser fortune to be more than that of John D. Rockefeller. Timber and Men, the Weyerhaeuser Company history, makes no mention of the exact amount of Frederick Weyerhaeuser's personal fortune.

${ }^{46}$ Appleman, "Timber Fmpire From the Public Domain", p. 202. 
were depleted to the point where it was no longer profitable to manufacture lumber on a major scale. The cloquet mills struggled on for another decade after the Cloquet fire, some years even losing money on their lumber production. Finally in 1928 the Weyerhaeuser lumber firms were dissolved, and their properties were taken over by Northwest Paper Company, another Weyerhaeuser firm.

Before leaving this era in the history of lumbering it is interesting in retrospect to note several significant milestones which had great influence on the later history of the industry. First, and most significant, was the fact that for the first time a definite leader had arisen from the ranks of the lumbermen. Frederick Weyerhaeuser and the organizations which he and his associates had developed became the standard after which other lumbermen patterned their own operations. Never before had the lumber industry witnessed such cooperation, organization, and success among a group of Iumbermen. By the time Weyerhaeuser moved into Minnesota with his operations, he seems to have established the pattern for future development: acquire vast timber reserves; acquire adequate logging, booming, and milling facilities; then integrate the whole operation. The result of Weyerhaeuser's success in following this plan was that the lumber business had its first true giant. No longer was it an industry composed entirely of many small independent operators, whose individualism and competitiveness was often their own undoing. Now lumbering was big business, and the Weyerhaeuser syndicate had made it so. Other significant aspects of this period of development are tied to the growth of Weyerhaeuser. Not only was the size of this organization unique to the industry at this time, but it often allowed or at times act- 
ually forced the Weyerhaeuser group to make additional advances in corporate organization and management. By the time they reached Cloquet their concept of cooperation was a proven principle. Initially it had. been restricted to solely the levels of logging, booming, and rafting. Now in Cloquet the size and proximity of the Weyerhaeuser mills demanded further efforts in cooperation. Mutual timberland purchases were made. Joint ownership of logging railroads was introduced. On the mill production level efforts were made to coordinate product lines, and separate, joint-owned manufacturing companies, such as the Cloquet Tie and Post Company, were established to mill the products which the parent firms could not or would not handle: In the distribution end of the business the first successful steps in the industry's history were made as the Cloquet mills disbanded their separate retail stores and consolidated into one retail outlet for the inmediate Cloquet area. At the same time the three firms made the move to establish joint wholesale outlets, opening offices in Minneapolis and Chicago in 1907 and acquiring a wholesale distribution yard in Buffalo, New York the same year. 47 All of these attempts at cooperation were turning points in lumbering history. Also, in the areas of conservation and labor relations definite attempts were finally initiated to alleviate reoccurring problems which

47 Hidy, Hill, and Nevins, Timber and Men, p. 192. Weyerhaeuser placed W.E.Thomas in charge of the Minneapolis office. After a successful career as a wholesaler, Thomas later left the Weyerhaeuser organization and established himself as an outstanding retail lumberman. Thomas built up a series of highly successful retail lumberyards across the southern edge of Minnesota with headquarters in Lake Crystal, near Mankato. By 1960, the organization was being run by a son and two grandsons. The holdings had dwindled to five retail yards, and it was obvious after calling on these yards in my capacity as a salesman for the Weyerhaeuser Sales Company that the dedication to the cause of lumber of W.E. Thomas had died with him. 
plagued the industry. By the turn of the century the need for these reforms was being forcefully pointed out by an irate public. The Weyerhaeuser syndicate because of its size and relative importance became a main target of these attacks. However, this great size while arousing suspicion was also the chief factor which allowed Weyerhaeuser to become the leader of the industry in developing enlightened conservation and labor policies.

In respect to the conservation problem, the Weyerhaeuser firms felt the full force of the pressure being brought to bear by the ground swell of public opinion against the so-called "Timber Barons" and their seemingly selfish exploitation of a basic resource. ${ }^{48}$ The culmination of this movement came with the Cloquet Burr which, rightly or wrongly, the public blamed on the lumbermen of Cloquet. Normally when such disasters had occurred in the past, the Iumbermen had merely picked up and moved on to the next forest, paying little heed to the blame placed on them by the public. But by 1918 the American public was no longer willing to overlook such a hugh loss of timber and of lives, and well aware of its power as a result of the successes of the Progressive movement during the first years of this century, it was unrelenting in its demands against the Iumber industry for reforms in conservation.

Similar pressure on the lumbermen concerning the labor problem was

48 The feelings of the public concerning the lumber industry were given voice through the efforts of the muckraking journalism of the period. Examples of these writings include Charles P. Norcross' "Richer Than Rockefeller - Weyerhaeuser"; Charles F. Russell's "The Nysterious Octopus: Story of the Strange and Powerful Organization That Controls the American Lumber Trade" (The World Today, February, 1912, XXI, pp. 1735-50.); Fmerson Hough's "The Slaughter of the Trees" (Everybody's, May, 1908, XVIII, pp.579-92.); and S.I. Whj.te's "The Fight for the Forests" (American Magaine, January, 1908, LXV, pp.252-61.). 
causing further anxiety. The threat of organized labor, particularly in the form of the International Workers of the World (IWW), who were in their heyday between 1910 and 1920, posed an increasingly formidable barrier to the continued abuse of the labor force by the lumbermen. The operators had had things too much in their favor for too long a time to give in meekly to labor's demands. Perhaps, if minor concessions could be initiated by the mill owners and some job stability established, labor would not organize to any great extent in the lumber industry. A final consideration was that the larger firms, particularly Weyerhaeuser, simply had too large a financial investment in their Minnesota holdings to pick up and leave.

Feeling these pressures, the Weyerhaeuser group attempted a daring experiment. They began to examine the possibilities of diversification inot other forest product fields. Since 1910 the Weyerhaeuser firm, Northwest Paper Company, had existed in Cloquet and had represented a definite attempt at diversification and at economic stabilization of the immediate area. But with the fire of 1918 and the lean lumber production years which followed it was obvious that Northwest Paper could not possibly take up all the slack. Many members of the syndicate, including Rudolph Weyerhaeuser, were discouraged to the point of giving up, but others expressed a desire to reconstruct Cloquet and find new products and new markets for the utilization of the remaining white pine timber and also the vast amount of weed species which escaped damage or which were bound to grow in place of the destroyed white pine. The result was the Wood Conversion Company, established in 1922 for the expressed purpose of turning these trees, formerly considered valueless, into profit. Mak- 
ing such products as insulation and acoustical ceiling tile from the fiber of the aspen, birch, and jack pine, this new company for the first time in the lumber industry's history began to make use of waste products. During the Twenties the combined operations of the rebuilt lumber mills, Northwest Paper Company, and Wood Conversion Company resulted in almost total utilization of the remaining timber. This was a big step toward a sound conservation policy. When the lumber mills finally did close, the other industries remained and were able to absorb many of the unemployed loggers and millhands. Many did move on west wi.th the lumber industry, but those who remained had a definite chance for an economic survival. Weyerhaeuser and the rest of the industry were beginning to learn the true value of both their natural resource and their human resource, and at last they were taking the initial steps in the conservation of both. 
CHAPTER III

The emergence of the first real giant in the lumber industry coincided with the end of the industry's dominance of the economy of the Upper Mississippi area. The trees were no longer available in sufficient quantity to sustain the continuance of Iumber production on a large scale. Once again the lumberman, albeit with his growing concern for conservation, decided the time was ripe to pick up and move on to the next forested area. With the stinging denounciations of the American public in general and the muckrakers in particular ringing in their ears the Minnesota and Wisconsin lumbermen began moving west.

It was the repetition of the old theme but with a new twist which posed seemingly insurmountable problems to many lumbermen who contemplated the move. The new forest was not "just over the next hill." Between the "next hill" and the western forest lay a vast expanse of open plains and two very formidable mountain ranges. The forests of the Pacific Northwest were most appealing, but what good were they to a lumber manufacturer if. there were no practical, economical way of getting the finished products to the country's major lumber markets in the Midwest and in the East?. Not only was the distance between mill and market a major problem, but the forest itself was causing great concern. Fxcept for the stand of white pine in northern Idaho, the timber of the Pacific Northwest was predominantly Douglas Fir. This was obviously a species high in commercial. value, but the tree grew to such a hugh size and in terrain so rugged that an entirely new concept of logging would 
have to be developed. Even the white pine of Idaho would require new methods of logging because it too grew in rugged mountainous country greatly different from the relatively even terrain in the Upper Midwest, which was we]l interlaced with navigable rivers. In the forests of Minnesota and Wisconsin the loggers had been able to take advantage of the cheap transportation offered by the horse drawn sleighs in the winter and the deep streams, rivers, and lakes in the spring and summer. In the forests of the West the mountainous terrain ruled out the use of sleighs. As for the waterways of the West, only the Clearwater River of Idaho could be used extensively for log drives, although other rivers and bodies of water were acceptable for log rafting operations. ${ }^{I}$

Initially the problem and the expense of logging would probably not have been too great for the forests located near these larger rivers and bodies of water could be logged, and the logs skidded directly to the water or to a nearby mill. The problem would come when the trees near the water had been harvested. The farther away from navigable water the forests were, the greater the expense of logging and Iumbering would become. With the interior terrain too steep and the size of the logs too great to use the sleighs, carts, and other logging rigs used in the midwest ern logging operations, it appeared that, if the timber of the West were to be exploited, new logging methods would have to be devised.

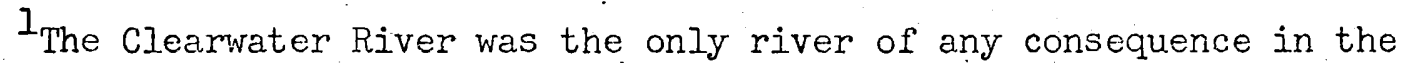
West used for log driving. Ironically, it is the only river in the United States today which still experiences the annual log drive complete with all the old time color and drama. Potlatch Forests, Inc. still uses the Clearwater each spring to drive their logs accumulated during the winter season from the woods down river to their Lewiston, Idaho manufacturing complex ("Idaho Loggers Battle A River", National Geographic, July, 1951, pp. 117-30. Also, see Ralph W. Andrews, Glory lays of Logging (Seattle: Superior Publishing Co., 1956), p. 83.). 
Ultimately, it would mean the buj.lding of expensive logging railroads, the use of the steam donkey and other heavy, mechanized equipment, and the development of completely new logging concepts, such as the high lead system. ${ }^{2}$ The prospects of such expensive logging costs, not to mention the expected increases in milling costs due to the heavier equipment needed to handle the larger logs, made the Midwest Iumbermen think twice about the proposed move to the forests of the Pacific Northwest. It was obviously going to kake a great deal of financial backing and no small amount of business courage to take advantage of the new situation.

In the years prior to 1900 only a handful of early lumbermen ventured into the Pacific Northwest woods. All of these tended to remain comparatively small in the size of their operations and for the most part completely independent of each other with little or no mutual recognition or communication. The first sawmill on the Coast supposedly was built in 1841 at Oregon City, Oregon on the banks of the Willamette River. ${ }^{3}$ Shortly after this mill was established, others destined to be more permanent and historically more significant were built in Oregon and Washington. Probably the first sawnill of any consequerce in the region was located in Seattle where Henry Yesler built his mill at tidewater on

2 The high lead system of logging involves the rigging of a spar tree with appropriate blocks and tackle. With the mechanical steam donkeys supplying the necessary power the logs are then attached to cables and skidded to the landing to be then loaded on to whatever means of transportation is available. Although used less frequently since the advent of "cat" (tractor) logging, the high lead system proved to be the most practical and often the only answer to logging the mountainous forests of the Pacific Northwest in the first half of this century.

3Holbrook, Holy Old liackinaw, p. 166. 
Puget Sound. The year was 1853.4 In 1854 Yesler received competition as the Pope and Talbot organization out of San Francisco began cutting at their twin milis located at Port Gamble and Port Ludlow, Washington. These mills and others in this early era intentionally located near the tidewater areas for two main reasons. First of all, there was the accessibility of the nearby timber which meant reduced logging costs. Secondly, with the major market for northwestern lumber at the time being in the export trade market, a mill to succeed and grow had to be able to service ocean going vessels. The more successful mills of the day chose the Puget Sound region over the Columbia River and other harbor areas along the Oregon and Washington coast because there was no bar to cross, thus eliminating a real danger.

However, the predominance of the cargo market and the importance of the cargo facilities did not stop other lumbermen from venturing into the hinterland. The Jones Lumber Company began operations in Portland in 1860, cutting lumber for the expanding local market of the willamette Valley. ${ }^{5}$. Sol Simpson came from Quebec to found the Simpson Logging Com-

${ }^{4}$ Stewart H. Holbrook, The Far Corner. (New York: Macmillan, 1952), p. 247. A skid road comprised of logs lea down the nearby hills to Yesler's mill. Logs were skidded down this road by oxen to the mill. As time went by, saloons, boarding houses, and other less respectable houses catering to the whims and fancies of the loggers and seamen were built along this road near the mill. Long after the Yesler mill was gone, the surrounding buildings and businesses remained as did the name for the area, skidroad. As Seattle grew up around this area, the old logging road become a street with the formal name, Yesler Way, yet even today Yesler Way is synonymous with skidroad. This was the original skidroad as the term is known today.

${ }^{5}$ The Jones Lumber Company finally ceased operations in 1962. The mill was eventually dismantled and the shipping sheds were leased to the Weyerhaeuser Company, which now uses them for a wholesale distribution center. 
pany at Shelton, Washington. The Minnesota lumbering firms of BrooksScanlon and of Shevlin-Hixon both chose the pine country of Bend, Oregon. C.A. Smith Lumber Company settled near tidewater at Coos Bay, Oregon, while the firm of McMillan-Bloedel began their early operations in British Columbia. Also, in Oregon John Yeon and Simon Benson built their personal fame and fortune on lumbering. The list of these early lumbering pioneers in the Northwest goes on and on as many historically famous names in both Washington and Oregon are traceable back to often humble beginnings in the initial phases of the region's lumber industry.

All of these early lumbermen staked out their own small domains in the Pacific Northwest, but none achieved a position of dominance during the latter years of the neneteenth century. Several factors combined to keep the various operators relatively small and independent. As had been the case in former lumbering regions, there was always a, great deal of competition. In spite of the fact that logging and milling on a large scale took a considerable amount of capital investment, it was also true that anyone with an ax, a saw, and the necessary desire could "get into the lumber business." There were always small tracts of timber for sale, and when the market - particularly the local marketwas favorable, the opportunity was often too enticing for many men to pass it by! In short, the early lumber industry of the region on the Coast was much like that of the other lumbering areas. It was basically easy to go into the business and just as easy to get out of it. Some were able to make a success of their venture. Others left after gaining their goals. Still others failed completely.

In addition to the Iure of the apparent financial opportunities 
which brought a number of relatively small lumbering operations to the region, there were other reasons why the early Iumbernen in Oregon and Washington remained small and independent. First, there was always the fact that the Pacific Northwest was too far from the major lumber markets of the country. Except for those mills on tidewater which could cater to the export trade, there were really no large sales possibilities for most mills once they had satisfied the local trade. Secondly, the traditional mistrust of these early lumbermen served to isolate them from their competitors and even the rest of the nation. This was the same mistrust which Weyerhaeuser had found in his early attempts to unite the Mississippi Valley lumbermen. Each operator tended to be highly secretive in his dealings and refused to share innovations in machinery and methods with his competitors. Such practices and attitudes could only serve to increase the provincialism and independence of the various lumbermen. Finally, the physical size and nature of the region actually acted against the operators, keeping them small and isolated. Communications in many areas were next to impossible as the extreme distances, the mountainous country, and the lack of navigable rivers kept travel down to a minimum. These geographical factors combined with the psychological factors of mistrust and secrecy, preventing the lumbermen from establishing any degree of uniformity within the industry. These early years in the Pacific Northwest saw no trade association, no grading rules, little manufacturing uniformity, no quality control, and no effort to understand the complexities of the lumber market.

The resulting independence of the small, individuel logging companies and lumber nills precipitated many additional problems which were 
as large in scope and as seemingly insurmountable as those which caused the plight of the lumbermen in the first place. The small size of their operations made it extremely difficult for most operators to handle the hugh Douglas Fir logs efficiently. To the increased expense incurred in logging this new species was acided the additional increased expense of milling the jouglas Fir logs. With logs often running from ten to sixteen feet in diameter, the milling equipment had to be made to a corresponding sjze. Few mill owners were willing and able to invest in much except the basic machinery needed to rough saw the Iumber. Those who did aspire to better their product and their production more often than not had to go deeply in debt to purchase the necessary machinery to do the job. This overextension of their credit many times proved fatal to their businesses when the lumber market took one of its periodic tailspins. 6

Marketing problems also resulted from this independence on the part of the operators. To begin with, there had to be a massive public relations campaign to sell the established lumber markets of the nation and the world on the superior merits of Douglas Fir lumber. Historically, pine had been the predominant softwood lumber species, and little was known of the quality and merits of Douglas Fir for the simple reason that it grew only in the Pacific Northwest and hence was virtually an unknown wood prior to the late $1800^{\prime} \mathrm{s}$. As long as the western Iumbermen

6 As author Paul Hosmer humorously puts it in his book, Now We're Loggin' (Portland: Binford \& Mort, 1930, p. 42.), "one year out of seven (in the lumber industry) is a good one, while the other six are steady and consistent losers, and the only ray of sunshine in the sky is the fact that the good year is a humdinger." Although the econornic cycles of the lumber industry have never been quite this precise, there has been over the years the tendency to feast or famine. 
remained small and independent, there was little hope of accomplishing this educational task. Funds and a cooperative, industry-wide effort were needed to get the message across. When neither of these factors was forthcoming, the individual members of the industry had to forget about the distant, more lucrative markets. Instead, they had to remain contented with what the local market had to offer and in doing so had to postpone any ideas of growth.

An additional aspect of the marketing problem faced by the mills of the Pacific Northwest was that their reluctance to join together in industrial associations cost them all in valuable market information. No Iumber manufacturer of that period had the means to finance his own complete marketing research. Again what was needed was the effort of an industry-wide association, studying the nation's demand for lumber and advising its members of its findings. In the absence of this information, the independent operators continued to follow the traditional milling and sales philosophy which has plague the industry even to this day. That philosophy was that the mill should produce what it could produce the best and then force the customer to buy the end product. At the time this philosophy might have worked had the mills still been in the Midwest, close to the major lumber markets which were still consuming vast amounts of lumber in meeting the construction demands of the ever growing midwestern population. But in the Pacific Northwest where the supply was great compared to the relatively small demand, this sales attitude often caused more harm than good. Mills more often than not were forced to curtail production until surplus production was sold, often at a loss. At other times they merely oversold the customer, thus 
forcing him out of the market for an unreasonable length of time. This only caused more surplus production in the industry, as there was usualIy no corresponding curtailment of production. This over-production problem constantly plagued the industry and was a major reason why the industry in the Pacific Northwest fared so badly in the economic panics of 1873 and 1893.7 Attempts at industrial associations were made following each of these panics, but once prosperity returned, the lumbermen went back to their traditional independent philosophies and began to produce as each felt best for his particular concern. Had the customers been allowed to dictate the type and quantity of production, the small mills might well have received the necessary stimulus to grow.

Finally, the problem of conservation was directly affected by the small size and independence of the Pacific Northwest lumber operations. Most of these Iumbermen had come from other areas and were for the most part familiar with the historical lack of conservation practiced by the industry. The reason the Iumbermen had had to move to the Pacific Northwest was basically centered around the conservation problem in former lumbering regions. They also could see that although the West had a fantastically large timber resource, it too could only last so long without a sound conservation policy. Obvious to all was the simple fact that this was the last great stand of timber in the nation. When it was cut, there would be no more. Nevertheless, the lumbermen, forced to remain small and independent by the combination of geographical,

7 In 1873 the wholesale price index for lumber was down to 75 $\left(1910-1914_{4}=100\right)$. In 1893 it slipped all the way to 60 (U.S., Department of Agriculture, Historical Forestry Statistics of the U.S. (Washington: U.S. Government Printing Office, 1958), p. 22.). 
economic, and physchological forces working against them, could adopt no other conservation policy but that which had failed so completely in other areas. The conservation policy of the early western Iumbermen became no conservation policy at all. The financial position of each operator dictated his policy. Few, if any, had sufficient financial means to cope with the problem of conservation. Lack of money meant little possibility of acquiring sufficient timber reserves which in turn meant that the emphasis was placed on the immediate short term gains. Such timber reserves would have allowed the timber owner to cut only when the market was favorable. Without the reserves the Iumberman was forced to purchase small tracts of timber and log them immediately, regardless of the market. As a result, much timber was indiscrim-. inately cut before maturity and without regard to reforestation or fire hazards. Lack of money also meant little or nothing was spent on fire prevention or control. If a purchased tract of timber was to be logged immediately, there seemed to be little sense in spending money on fire precaution measures, such as roads and lookouts. Consequently, the region suffered disastrous forest fires in the late $1800^{\prime}$ s and the early 1900 's. 8

8 Nost of the great forest burns in the Pacific Northwest have been in Oregon. The first recorded forest fire was in 1846 (Yaquina Burn). There followed the Nestucca. Burn (1860), the Coos Burn (1868), the St. Helens Burn (1868), the Yacolt Burn (1902), the Tillamook Burn (1933), and the Bandon Burn (1936). The State of Washington also shared the St. Helens Burn of 1868 and the Yacolt Burn of 1902. (Holbrook, Burning An Fmpire, pp. 108-20). It is significant that Oregon during this period. had more small, independent lumbering operations than did Washington (Hidy, Hill, and Nevins, Timber and Men, p. 219). In 1935 there were a total of $479 \mathrm{mills}$ operating in western Oregon and $423 \mathrm{mills}$ in western Washington (West Coast Iumber Association, West Coast Lumber Facts (SeattIe: West Coast Lumber Association, 1936), p. 16). 
Other practices of the period failed to observe basic rules of conservation. The early loggers lacked sufficient equipment to cope with many of the hugh trees. The bark layer around the base of the Douglas Fir was often so thick and tough that it was often easier to cut the trees as much as ten or twelve feet above the ground. Also, the high stump was considered a necessity along the coastal area due to the dense undergrowth resulting from the heavy rainfall.9 Besides the waste of the high stumps, there was also the waste caused by the logging rule of the early days in the Pacific Northwest which prevented logs of less than sixteen inches in diameter from being sent to the sawmill.10 The mills felt that they could not make money milling these relatively small logs. The affect of this practice in retarding conservation can not be underestimated. It was certainly not total utilization of the tree.

Furthermore, the small mills actually were not capable of full. utilization of the trees at this time for they had equipment capable only of rough sawing lumber. In this respect they probably can not be blamed for not wanting to take either the smaller logs of Douglas Fir or the supposedly inferior species of the Northwest forest, such as hemlock and the true firs. ${ }^{11}$ However, the operators can be held responsible for their practice of leaving these Iogs and trees in the woods where they

9Ralph W. Andrews and Iarius Kinsey, This Was Logging (Seattle: Superior Publishing Co., 1957), pp. 36-38.

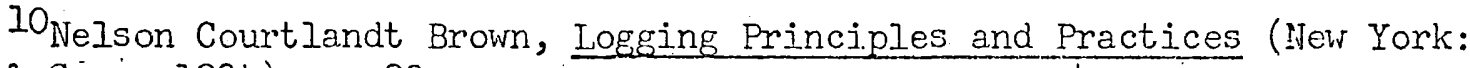
Wiley \& Sonș 1934), p. 90.

1IDouglas Fir is actually a species unto itself. The true firs belong to the Abies family. 
became prime targets for insects, disease, and fire.

The lack of conservation coupled with the problems of manufacturing and marketing all combined to frustrate the early lumbermen of the Pacific Northwest. Because of these many and varied problems confronting the industry in this region at the close of the nineteenth century, the outlook for the future was highly questionable. The natural resource was available in a quantity and quality which far surpassed former lumbering areas. However, it appeared that the lumber industry was to remain relatively small and mostly local in scope unless the opportunity to overcome the basic problems of the industry was provided to stimulate growth. This opportunity finally was given to the struggling industry. One key to the solution of the problem came from within the industry itself as certain lumbermen moved to integrate and organize the industry in the Pacific Northwest. The other key was found in the changing policies toward and the growing interest in the Pacific Northwest region by the transcontinental railroads. Ii fact, the emergence of the lumber giants in the Pacific Northwest and the arrival of the transcontinental railroads on the Coast were almost simultaneous and very definitely related. 
CHAPTER IV

By the late 1800's it was apparent that the future economic development of the Pacific Northwest hinged upon the development and the policies of the major railroads which were by then nearing completion and would link the region with the rest of the nation. More specifically, the future of this region depended upon the policies and actions of one man, namely Janes $\mathrm{J}$. Hill, for by the last decade of the nineteenth century Hill was in control of both the Great Northern Railroad and the Northern Pacific Railroad. The Great Northern, reaching from St. Paul to the Puget Sound, was completed in 1893, and with its completion Hill was confronted with the problem of creating enough freight business to make the new railroad pay. He rose to the challenge, and his resulting grandiose scheme encompassed not only the economy of the Pacific Northwest but also the economy of the rest of the United States and even that of the Orient! Although never realized in its entirety, Hill:s great plan for linking the United States with the Far East through trade in no small way added to his reputation as the Empire Builder. The keystone for the success of the entire plan seemed to be the potential lumber production of the Pacific Northwest. As Hill himself explained his scheme,

A study of the lumber trade revealed the first favorable opening. When the railways reached Puget Sound, they found there the largest supply of standing timber in the world. For this there was at that time but a limited market. It reached the outer world only in the small quantities that sailing vessels carried up and down the coast or to foreign ports. The freight rate to the East, where alone it could be sold extensively, where the demand for it was greatest, was ninety cents per hundred pounds. This was prohibitive. The question 
was how to make a rate low enough to bring this lumber to the prairie country and the Mississippi Valley. It could be done only by securing an ample and steady volume of traffic in both directions, so that neither eastbound nor westbound cars should be hauled empty. Low rates can be made only if cars moving in each direction are loaded. I

In the late 1800 's the railroads were carrying much more to the West than they were hauling eastward from the region. Lower freight rates on West Coast lumber would solve this problem, but in doing so it would more than likely create an additional problem. Hill envisioned such an increase in lumber shipments to the East and Middle West as a result of the lower frejght rates that the railroads would soon be shipping empty cars westward. Assuming that such a problem would develop, Hill reasoned that

- . westbound business would have to be increased again, else empty cars would be travelling nearly two thousand miles to the Pacific Coast. While the local development of the coast country was sure to be great, it would not supply sufficient volume of business at that time to equalize traffic. A market for our products in the Orient, if it could be built up, would not only do this but would be of the utmost value to every interest in this country. . . The first steps had to be taken and the whole burden assumed by the railroads. 2

According to Hill, the primary key to the success of his plan was the establishment of a favorable freight rate for the West Coast Iumber. Taking into consideration the fact that in order to compete in the world market American suppliers had to keep their prices reasonable and also the fact that the anticipated volume of lumber freight might well offset any possible financial loss due to a lower freight rate, Hill decided that he should take a gamble and lower the freight rates on lumber, at

\footnotetext{
IJames J. Hill, Highways of Progress (New York: Doubleday, Page, \& Co., 1910), pp. 158-59.

Ibid., pp. 159-60.
} 
least temporarily. He did lower them even lower than suggested by the Iumbermen of the day, hoping to give the western region the economic stimulus it needed to get on its feet. He justified this extremely low rate in the following manner:

The lumber business of the Pacific Coast made possible the naming of a rate that should open to us the closed doors of the transPacific East. The details then worked out have not lost their interest as a part of our economic history, although the splendid possibilities they revealed have gone.

At the beginning, the key to the situation was the lumber rate. There were 400,000,000,000 feet of standing timber on the Pacific Coast. It could not pay the ninety-cent freight rate to the East at that time, when lumber prices were but a fraction of what they are now (1910). The railroads could not afford to haul empty cars West to carry that lumber East. It costs, roughly, $\$ 160$ to haul a car 2,000 miles across the continent. But they could afford to carry lumber temporarily at a low rate rather than bring cars back empty. And if in this way the lumber business could be developed, it, in turn, would make possible later a low westbound rate, on which trade with the Orient could be built up.

The lumber men of the Pacific Northwest said that while the ninetycent rate shut them out of the eastern market, they could pay sixtyfive cents and do business there. Market conditions at that time seemed, however, to require a rate of not to exceed fifty cents. The railroads off'ered a forty-cent rate on fir and fifty cents on cedar, and those rates went into effect. In 1900 the state of Washington produced 1,428,205,000 feet of lumber; only six years later its product was $4,305,053,000$, with a total value of $\$ 62,162,840.3$

Hill did not have to search very far to find the most able representative of the lumber industry. In 1891 Frederick Weyerhaeuser had moved to St. Paul, and his next door neighbor from 1893 until his death in 1914 was Jim Hill. During the 1890's these two giants of American industry spent many evenings discussing the mutual problems of lumbering and railroading in the West, and out of these talks there eventually developed a friendship and a business relationship which was to greatly enhance the fortunes of both men and their respective business ventures in

$$
3 \text { Ibid., p. } 163 .
$$


the Pacific Northwest. 4

Hill was not only concerned about such long term matters as how he could build sufficient volume on his railroads so that they would. be profitable, but while the lines were still being built, he was faced with the reoccurring problem of obtaining proper finances for the actual construction. As has already been pointed out, he placed his hopes for the solution to the long range problem on the great potential lumber business of the Pacific Northwest. The Iumber industry also provided one of the better answers to the more urgent question of financing the building of the railroads, for it represented a ready customer for the timber that $\mathrm{Hill}$ had acquired through the land grants given to his railroads, particularly the Northern Pacific.

In time the eventual timberland purchases from Hill's Northern Pacific Railroad by the Weyerhaeuser Timber Company were to be most important to the growth of both the $\mathrm{Hill}$ interests and the Weyerhaeuser empire. The Northern Pacific during its years of development and construction had amassed a huge amount of land. The Federal Land Office which controlled the allocation of land grants to the railroads seems to have been most liberal in their efforts to encourage the builders of the Northern Pacific to complete their transcontinental line. In the end the railroad had been given the option on approximately 44,000,000

4Frederick Weyerhaeuser's son, Frederick E. Weyerhaeuser, assumed James J. Hill's directorship seat on the Board of the Northern Pacific Railroad at the latter's death in 1916. Even today the close association is still in evidence. Frederick $K$. Weyerhaeuser is at present a member of the board of directors of both the Weyerhaeuser Co. and of the Great Northern Railroad (Poor's Register of Corporations-1965 (New York: Standard \& Poor's Corp., 1966), pp. 691 and 1674). 
acres of land along its proposed right of way. By 1910 it had patented $32,664,651$ acres of this grant. The final settlement of the Northern Pacific land grant in 1941 showed that a total of 39,843,053 acres had actually been patented. 5 Included in this acreage were vast tracts of timberland, the ownership of which made the railroad the nation's second largest timber owner in 1900, surpassed only by the Southern Pacific Railroad.

Since the Northern Pacific was not in the logging or samili business, James Hill naturally was looking for lumbermen who could and would handle the job. For Hill the sale of these timberlands would solve both his irmediate and his long range problems, for it would mean needed cash and also the lumber manufactured from the timber would give the Northern Pacific and the Great Northern the volume of freight needed to make these transcontinental railroads pay.

Hill in his search for potential buyers of this timberland had to look no farther than over his fence, for by the late $1890^{\prime} \mathrm{s}$ his neighbor, Weyerhaeuser, could begin to see that the inexhaustible pine forests of Minnesota would soon be exhausted, just as were those of Wisconsin, Michigan, and Maine. However, Frederick Weyerhaeuser was no easy sale. He and the members of his organization held serious reservations about the ability of western lumber being able to compete in the midwestern and eastern markets due to the prohibitive freight rates. As has already been shown, Hill answered this question by eventually setting. very favorable freight rates for West Coast lumber on his lines, betting

5.M. Ellis, "The Forfeiture of Railroad Iand Grants, 1867-1894", Mississippi Valley Historical Review, June, 1946, XXXIII, No. I, p. 45. 
on volume to make him the necessary profit.

Secondly, Weyerhaeuser guessed correctly that it would be nore expensive to $\log$ and mill the Douglas Fir and other western species. The logs were so large and the terrain so rugged that almost completely different methods and equipment would have to be devised. Also, there was a transportation problem between forest and sawmill which would have to be solved, for unlike the streams and rivers of previous forests the forest streams of the West were too shallow and otherwise unsuitable for the log drive type of logging. Only in northern Idaho were there river conditions similar tó Minnesota and Wisconsin. Elsewhere. in the Cascade Range and the Coast Range of nountains expensive logging roads and railroads would have to be built.

The other worry of Weyerhaeuser was the possibility that since he was also considering the opportunity to invest rather extensively in timberlands in the South at this time, such financial adventures in the distant and remote West might over-extend his group.

However, the combination of the choice western timber, the dwin-. aling midwestern timber supply, and the persistence of $\mathrm{Hill}$ in the end sold Weyerhaeuser on the West. Timber and Men records this initial western sale in these words:

Then in 1900 came a transaction that startled the West. . . the Weyerhaeuser office announced the purchase from the Northern Pacific of 900,000 acres of timberland at $\$ 6$ dollars an acre . . .

A little later this purchase was to seem a colossal bargain. The Bureau of Corporations within a dozen years estimated that in terms of the probable cut the price was only ten cents a thousand feet.

Nevertheless, at the time many thought the investment exceedingly speculative... In short, so great a purchase required courage.6

6 $\mathrm{Hidy}, \mathrm{Hill}$, and Nevins, Timber and Men, p. 213. 
In reading this account, one gets the feeling that although the deal was big and the accompanying risks in proportion to the money involved, Weyerhaeuser and his associates had the great combination of courage, foresight, money, and luck necessary to pull off such a bargin. One senses no small amount of pride in the above account. Today, at least within the lumber industry in general and within the Weyerhaeuser Company in particular, this timberland purchase is legend.

Unfortunately, the authors of Timber and Men and most Weyerhaeuser people today fail to mention the historical background leading up to this land sale. Knowledge of this background puts the transaction into perspective and gives a much better understanding of just how and possibly why such a colossal deal took place when and where it did.

By 1912 it was quite clear that the private ownership of the nation's western timberlands had been concentrated to a large degree into the hands. of just three concerns. Table 6 on the following page reveals an interesting feature of the relationship between the Northern Pacific Railroad and the Weyerhaeuser Timber Company. At this date the Northern Pacific was in third place in private ownership of timberlands. It had lost its second place rating to the Weyerhaeuser Timber Company through the sales of vast amounts of its timberland to the latter firm. Although some of the land transfers involved original land grants, many were sales involving exchange lands. As such, much of the timber involved in these sales was not timber acquired directly from original land grants to the railroad, but instead, it was on land which had been received in exchange for land originally granted the Northern Pacific, much of which was considered to be comparatively worthless. 
TABLE 6

TIMBER HOLUINGS IN THE PACIFIC

NORTHWEST ANJ CAIIFORNIA OF THE

THREE LARGEST PRIVATE OWNERS - 19127

\begin{tabular}{|c|c|c|}
\hline & $\begin{array}{c}\text { Timberland } \\
\text { (acres) }\end{array}$ & $\begin{array}{c}\text { Timber } \\
\text { (bjllion feet) }\end{array}$ \\
\hline Southern Pacific Railroad & $3,841,816$ & 105.6 \\
\hline Weyerhaeuser Timber Company & $1,903,995$ & 95.7 \\
\hline Northern Pacific Railroad & $2,979,023$ & 36.2 \\
\hline
\end{tabular}

In 1897 Congress passed the Pettigrew Amendment to the Sundry

Civil Appropriations Act. This amendment pertained directly to the

government's land policy and stated

That in cases in which a tract covered by an unperfected bona fide claim or by a patent is included within the limits of a public forest reservation, the settler or owner thereof may, if he desires to do so, relinquish the tract to the Government, and may select in lieu thereof a tract of vacant land open to settlement not exceeding in area the tract covered by his claim or patent. 8

This is the famous "land lieu" or "forest lieu" law. For the holders of the large land grants, such as the Northern Pacific, it meant that any part of their land grant which was now or in the future included within the boundaries of a public forest reserve, i.e., a National Park or a National Forest, could be exchanged for an equal amount of land from the

7U.S., Department of Commerce, The Lumber Industry (Washington: U.S. Government Printing Office, 1914), II, p. 69. AIthough the Southern Pacific Railroad was in 1912 the largest private owner of timber in the United States, it soon became second to the Weyerhaeuser Timber Compuny. The Southern Pacific had to forfeit most of itș vast Oregon land holdings to the government in legal actions which began in 1913 and ended in 1916. The Southern Pacific lost its land on the grounds of alleged violation of the conditions of its grants.

8The Statues of the United States of America: Narch, 1897 to March 1899 (Washington: U.S. Government Printing Office, 1899), XNX, p. 36. 
public domain. However, the legal interpretation of this new law imposed a further restriction on the terms of exchange which greatly. altered the effects of the law. It was ruled that land taken in lieu of the original grant must be surveyed land. Because of this subsequent restriction, there was little action taken by the various companies holding such land for the first year or two after the law was passed. During the period between 1897 and 1900 there was a total of only 71,000 acres exchanged. 9

At this sarne time, however, Congress was also considering the establishment of Mt. Rainier National Park in the State of Washington. Included within the proposed boundaries of this park were many thousands of acres of the Northern Pacific's land grant. Hopeful of gaining more favorable exchange terms than those granted by the Pettigrew Amendment, the representatives of the railroad successfully brought lobbying pressure to bear upon Congress. The final wording of the vit. Rainier Nat-ional Park Act more than satisfied the hopes of the Northern Pacific officials and also the lumbermen who were interested. A specific section pertaining solely to the Northern Pacific was inserted to cover the disposition of its indemnity lands within the new park. This section states

That upon execution and filing with the Secretary of the Interior, by the Northern Pacific Railroad Company, of proper deed releasing and conveying to the United States the lands in the reservation hereby created, also the lands in the Pacific Forest Reserve which have been heretofore granted by the United States to said company, whether surveyed or unsurveyed, and which be opposite said company's constructed road, said company is hereby authorized to select an equal quantity of nonmineral public lands, so classified as non-

9Appleman, "Timber Empire From the Public Domain", p. 202. 
mineral at the time of actual Government survey, which has or shall be made, of the United States not reserved and to which no adverse right or claim shall have attached or have been initiated at the time of the making of such selection, lying within any state into or through which the railroad of said Northern Pacific Railroad Company runs, to the extent of the lands so relinquished and released to the United States.10

This law was most valuable to the Northern Pacific interests in the subsequent disposal of their timberlands for several reasons. First, the railroad could now exchange the land it held within the park boundries for either surveyed or unsurveyed lands. This meant that choice timberlands in Washington and Oregon which had never been opened to public entry could now be exchanged in lieu of land held both within the new park and also within the Pacific Forest Reserve. The effect was immediate. Other private owners of timberland grants asked for and received the same concession regarding exchanges for either surveyed or unsurveyed land, and during the year 1900 the total amount of acres exchanged by all private owners jumped from 71,000 acres to 523,000 acres. 11 The Northern Pacific in particular began more and more to exercise its option under the new law to exchange its indemnity lands. Between 1899 and 1914 the railroad relinquished a total of approximately 450,000 acres of land within the park or the Pacific Forest Reserve, comprised primarily of comparatively worthless mountain lands, for which some of the nation's most valuable timberland was obtained in lieu. 12

Second, the Mt. Rainier Act gave the Northern Pacific the right to cruise the timber of any prospective lieu lands prior to any exchange.

10 30 stat., p. 994.

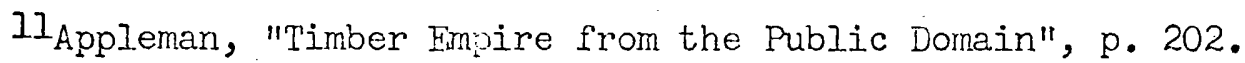

12The Lumber Industry, I, p. 237 
As a result, the railroad was able to gain an accurate estinate of the arnount and condition of the timber on these lands before committing itself to an exchange. Naturally, the most heavily timbered lands received the primary consideration, for the railroad had little intention of retaining such lands. Its eyes were focused on future sales to the lumbermen.

A third and final significant feature of the law was that there was no restriction placed on potential lieu lands in regard to whether they should all fall within odd numbered sections. The original grant had given the railroad only the odd numbered sections of land bordering along its right-of-way. Since there was no such specific restriction under the new law, the Northern Pacific or anyone who had purchased Iand liou scrip from the railroad could choose both odd numbered and even numbered sections of land. The significance of this feature was twofold. First, choice timberlands in even numbered sections were now available. Secondly, it gave the potential owner the opportunity to block his timber stand which would make future logging operations much more efficient and profitable.

Whether the Northern Pacific acted alone in these transactions or whether Weyerhaeuser was the moving force has never been accurately determined. Timber and Men strongly defends the innocience of both the Northern Pacific and Weyerhaeuser:

Circumstances negate this theory (that the Northern Pacific and Weyerhaeuser had plotted to scheme and pressured the government to pass such favorable legislation). The Northern Pacific land office was not concerned, and the Weyerhaeusers... had no interest in Northern Pacific lands.13

13 Hidy, Hill, and Nevins, Timber and Men, p. 293. 
In view of the events and personalities involved prior to and following the passage of both the Pettigrew Amendment in 1897 and the Mit. Rainier National Park Act in 1899 it is hard to take such an assertion at face value. First of a.ll, it has already been pointed. out that Hill was vitally concerned with the forest lands of the Pacific Northwest and their obvious relationship to the success or failure of his railroad ventures. As for Frederick Weyerhaeuser, to say that he had no interest in the western forests in general and in the western forest holdings of the Northern Pacific in particular is beyond belief. By the 1890's Weyerhaeuser was the nation's foremost lumberman, and one of the reasons he had attained this position of leadership was that he was interested in all timber anywhere. His close personal relationship with Hill during the 1890's and early 1900's not only made him aware of the Northern Pacific's vast holdings, but it also gave Weyerhaeuser's syndicate the inside track on future sales of this timber. In fact, it is most significant that it was at just this precise time (1897 to 1900) that the Weyerhaeuser people began to show real interest in the possibilities of the Pacific Northwest region. In 1898 with the incorporation of the Coast Lumber Company and in 1899 with the organization of the Sound Timber Company the Weyerhaeuser group made their initial ventures in the Pacific Northwest lumber industry. ${ }^{1 / 4}$ These were made independent of any timberland purchases from the Northern Pacific Railroad.

of great sugnificance too is the fact that the tremendous 900,000 acre transaction between the railroad and Weyerhaeuser was

$$
14 \text { Ibid., p. } 212 .
$$


completed in 1900, just a year after the favorable terms of the Mt. Rainier Act went into effect and the same year that the Weyerhaeuser syndicate organized the Weyerhaeuser Timber Company with headquarters in Tacoma, Washington. Included in these 900,000 acres were some of the very same exchange Iands from the Northern Pacific's indemnity holdings within the National Park and the Pacific Forest Reserve. It is very likely that Weyerhaeuser supplied many of the timber cruisers to cruise the prospective lieu land of the railroad since in many instances the Weyerhaeuser Timber Company purchased not the Iieu land per se but lieu land scrip which could be exchanged for lieu land at their convenience.

By 1914 the Weyerhaeuser Timber Company had purchased a grand total of $1,525,000$ acres of timberland in the Pacific Northwest from the Northern Pacific Railroad, including the original 900,000 acre purchase. This amount constituted approximately eighty percent of the company's entire land holdings. 15 of this total, approximately 220,000 acres had been obtained through purchases of exchange land or land lieu scrip which the Northern Pacific had received as a direct result of the Mt. Rainier Act. Other Weyerhaeuser controlled companies acquired an additional 97,000 acres of this land and/or scrip, making the total. Weyerhaeuser take approximately 317,000 acres or seventy one percent of the approximately 450,000 acres exchanged by the Northern Pacific under this law. 16

Thus, the Weyerhaeuser group was able to accomplish in a few short

${ }^{15}$ The Lumber Industry, II, p. 7.

16Ibid., I, p. 239. 
years what it had taken thern some fifty years or more to achieve in the Upper Midwest, namely gain ownership or control over vast amounts of a given region's timber resource. Once again they proved to be the most successful lumber interest in the struggle to gain control over the industry. But there were also others who shared to some extent the success of Weyerhaeuser in seizing the opportunity to carve out empires from the timberlands originally given to the western railroads. In Oregon the well known early lumber concerns of Booth-Kelly, of C.A. Smith, and of A.B. Hammond were the principal benefactors from the disposal of the vast holdings in the state of the Southern Pacific Railroad. 17 The Northern Pacific, in addition to the Weyerhaeuser Timber Company purchases, sold timberlands to the Smith and Hamnond interests. Also, the Shevlin interests, another early Pacific Northwest lumbering power, were able to gain a large concentration of timberlands through the Northern Pacific sales. 18 In fact, most, if not all, of the present day major lumbering and wood products firms in the Pacific Northwest can trace the reason for their favored industrial position in terms of ownership of timberlands either directly or indirectly to the early generosity and cooperation of these railroads. Even firms such as Georgia-Pacific Corporation and the U.S. Plywood Corporation, which are relatively new giants in the industry, owe their size to the fact that they have been able to purchase large tracts of forest lands from such concerns as Booth-Kelly and C.A. Smith when these latter firms ceased operations.

17Ibid., II, pp. 56-58.

18 Ibid., I, p. 239. 
Whether these original transactions were all legitimate and were free of any conspiracy to rob the public domain of a valuable natural resource for the finanical gain of a few or whether there actually was illegal collusion for personal gain on the part of both the railroads and the lumbermen has never been proven. As with other industries at the turn of the century, the lumber industry came under heavy fire from the muckrakers and others in an effort to establish the blame for the rapidly dwindling amount of forest land in the public domain. The seemingly mysterious circumstances surrounding some of the huge timberland sales which concentrated the nation's forest wealth in the hands of a select few plus the awakening fear that these few would continue in the West the same wasteful lumbering practices which had been the rule in the East and Upper Midwest aroused the clamor of the general public for reform. This clamor on the part of the public Ied men of authority, namely Teddy Roosevelt and Gifford Pinchot, who was the head of the newly created U.S. Forest Service, to investigate and regulate the so-called Timber Barons. President Roosevelt moved rapidly to place remaining unclaimed timberlands into federal reserves through the creation of the National Forest system. He also authorized the creation of the Bureau of Corporations within the Department of Commerce for the expressed purpose of examining the activities of the nation's major business concerns. One of the first jobs of this new bureau was to conduct an extensive investigation of the lumber industry to determine the precise amount of concentration in the industry. The results of this study are found in the four volume, 1,498 page monograph, The Lumber Industry, published in 1914. This study showed that 
there was definitely a concentration of timberland ownership in the hands of a small number of firms. However, no conclusions are reached as the the legality of such concentration. Although there were many transactions which could be questioned in regard to their concern for the good of the general public, this report places little or no actual blame on any one group. Instead, it implies that the concentration resulted from a combination of many factors, including a general apathy on the part of the public, loosely worded and loosely enforced legislation, and extremely shrewd businessmen whose expanding business fortunes were acquired for the most part quite legally in respect to the existing social, economic, and political ethics of the period.

In retrospect it is interesting to reflect upon the dreams of James Hill. Although parts of his master plan were never realized, the belief that the development of the Pacific Northwest hinged upon the success of the lumber industry was proven almost as soon as the railroads reached the Coast and made the necessary concessions to. generate and inspire confidence in the lumbermen to invest extensively in the region. The development of the Pacific Northwest is a prine example of the concept expressed by one author that "Communication, not production, was the key to industrialism in the United States."19 This was doubly true in the Pacific Northwest. First of all, without the transcontinental railroads linking the region with the more populated parts of the nation the Iumber industry of the area was doomed to be rather provincial and consequently small. Secondly, the rilling-

19T.C. Cochran and W. Miller, Age of Enterprise (New York: Macmillan, 195.2), p. 57. 
ness of the railroads to part with their choice timberlands in the region allowed the lumber industry to immediately concentrate a large share of its power in the hands of a few, thus eliminating many of the problems the industry faced while becoming established in other areas of the country. In short, the railroads opened the Pacific Northwest for the lumber industry which in turn developed to sustain the operation of the railroads.

The actions of the railroads worked miracles in transforming the fledgling lumber industry of the Pacific Northwest into a major industry. The primary effect of the large timberland purchases by the lumbermen from the railroads in the first years of the twentieth century was that it constituted the initial step in the concentration of power within the industry. Ownership of such vast reserves of the natural resource opened the door for more efficiency in logging and milling practices. . The primary effect of the lower freight rates was that now the lumbermen of the West could share in the hugh domestic lumber market of the East and of the Midwest. These new rates paved the way for more aggressive marketing efforts, particularly on the part of those lumbermen who could provide the greatest supply. These new considerations made the large, integrated operation practical.

The transformation in the Pacific Northwest did not take place immediately, however. The hugh timberland purchases by such concerns as Weyerhaeuser, C.A. Smith, and the others temporarily drained their finances, and for the first few years of the 1900 's the older, more established mills in the area continued to lead in lumber production. Production figures for 1905 reveal that the St. Paul and Tacona Lumber 
Company and the Pope and Talbot mills led the industry in the Pacific Northwest with a total lumber production for the year of $125,000,000$ board feet and $84,000,000$ board feet respectively. In contrast, the total production of the Weyerhaeuser Timber Company in 1905 was a meager $39,000,000$ board feet of lumber. 20

These production figures are not only significant in that they show the size of the early mills, but they also reveal that a definite change was imminent within the industry, at least in respect to market orientation. By 1905, the new low freight rates were in effect, and although the cargo business was still primary, it was apparent that the rail market held the greater possibilities, at least for those mills with rail connections. In 1905 Pope and Talbot with their twin tidewater mills at Port Gamble ard Port Ludlow, Washington, shipped ninety percent of their production via cargo. ${ }^{21}$ Weyerhaeuser's lone mill at Everett, Washington, which had been purchased in 1902, shipped approximately sixty percent of its 1905 - 1910 production by rail to the Upper Midwest. 22 Since many of the tidewater cargo mills had poor rail connections, they had to remain cargo mills, and as a result their growth was stymied. In contrast, the mills with good rail connections began

20E.T. Coman and Helen M. Gibbs, Time, Tide, and Timber (Stanford: Stanford University Press, 1949), p. 446. The comparative smaliness of these early mills in the Pacific Northwest is brought sharply into focus when it is noted that Weyerhaeuser Company:s current operation at Longview, Washington, is capable of cutting approximately $1,000,000$ feet of lumber in a single day! In 1964 the total lumber production of Weyerhaeuser was 1,607,000,000 board feet (Weyerhaeuser Co., Annual Report - 1964 (Tacoma: Weyerhacuser, 1964), p. 32.).

2IComan and Gibbs, Time, Tide, and Timber, p. 446.

22Hidy, Hill, and Nevins, Timber and Men, p. 233. 
to concentrate on the California and Midwest markets now that they could compete in regard to price. So great a factor was this opportunity to increase rail business that Weyerhaeuser's Everett mill in the period between 1905 and 1910 chose to ship only ten percent of its total production via cargo. 23 All indications pointed to a major change in the organization of the Pacific Northwest lumber industry.

23Ibid. 


\section{CHAPTER V}

What occurred within the Iumber industry in the Pacific Northwest region from 1905 on was much the sane sort of consolidation of power that had occurred in the Upper Mississippi Valley after many years of individualism on the part of the separate lumbermen. In the western region the concerns which were to grow the most and in doing so become the most powerful were generally some of the same ones who had initiated the ideas of cooperation and trust in the Nidwest. Using the experience and financial power they had acquired from their Minnesota, Wisconsin, and Michigan operations, these few lumbermen were able to take the best advantage of the conditions in the Pacjfic Northwest. at the turn of the century. Once they got control of the major share of the region's timberlands and began building their larger, more modern sawmills, these new concerns began a growth which far surpassed that of the older mills in the region, and as a result the lumbering industry itself began to take on a newer, more modern look. Although the small operations certainly did not fade completely away in the face of the new competition, the few large timberholders and mills rapidly became the real heart of the industry.

As these lumber giants began to emerge, it was evident that only one held the key to achieving any real dorninance over the entire industry. This firm was the Weyerhaeuser Timber Company. Realizing that the main factor in the success or failure of a lumber company is the degree of control it has over the raw material, Weyerhaeuser and his 
cohorts with their vast purchases from the railroad timberland holdings now held the necessary timber reserves needed to assure success in the years to come. As had been the case in Wisconsin and líinnesota, the Weyerhaeuser syndicate could now proceed at their own pace to build their lumber empire in the West. In time this western operation of the Weyerhaeuser group was to far surpass their midwestern achievements. In fact, the success of the Weyerhaeuser Timber Company was so outstanding compared with their competitors that any study of the concentration of power within the lumber industry of the Pacific Northwest must in reality be a study of the development of the Weyerhaeuser firm. As was seen in the preceeding chapter, the Weyerhaeuser Timber Company spent the early years of the 1900's buying up as much choice timberland as it could find. The firm and its leaders were often overextended financially with these purchases, and often they were accused of hording the timberlands, buying and holding solely for the purpose of reselling later at large profits. This attitude of their opponents seemed justified when the firm made no major attempts to acquire milling operations during the initial years of its existence. However, Weyerhaeuser and his friends had no such intentions. They were not going West merely to speculate, nor were they intending to become merely a timberland management operation in the Pacific Northwest. Contrary to their competitor's and opponents' beliefs, the Weyerhaeuser Timber Company had as its ultimate objective the manufacture of lumber. ${ }^{2}$

The fact that it took the firm some fifteen years to cement its basic position in the region before it began to manufacture lumber on a $I_{\mathrm{Hidy}}$, Hill, and Nevins, Timber and Men, p. 278. 
large scale is indicative of the caution, planning, and thoroughness of Frederick Weyerhaeuser. From his earlier experiences, he knew that the success and Iongevity of his western operations depended upon having adequate timber reserves. Weyerhaeuser and his associates also grasped the fact that these timber reserves had an added significance in the West for it was the last remaining stand of commercial timber left in the United States. If the Weyerhaeuser Timber Company was to be a permanent establishment, it would require a vast reserve of timber. For these reasons, Weyerhaeuser was willing to forgo immediate profits, concentrating instead on timberland acquisitions. ${ }^{2}$

From 1900 to 1915 the Weyerhaeuser Timber Company concentrated its efforts on expanding, consolidating, and organizing its timber reserves. The great purchases from the Northern Pacific Railroad needed to be cruised, and their true value and nature assessed. Inferior tracts of timber needed to be traded or sold for more choice stands. The checker board effect of the railroad grant presented the firm with the problem of exchanging odd sections of land for even sections with the railroads, the government, and other timber owners. The results of all of these early efforts in timberland management were obvious when the company finally decided to make the venture into the manufacturing field. By 1915 Weyerhaeuser knew what it had in the way of raw material. This control, organization, and knowledge of the resource was to prove in-

2 It has been said that Frederick vieyerhaeuser "would buy timber anywhere, but would sell none" (Holbrook, Holy Old Nackinaw, p. 157.). Although this is not quite accurate, it is true that Weyerhaeuser's philosophy concerning the acquisition of timberlands was probably the basic reason for the success of his business ventures. In reality, he often did sell some of his timber holdings, but they were almost always sold at Weyerhaeuser's terms. 
valuable to the firm in its drive to the top of the industry. While they were organizing their timberland domain, the leaders of the Weyerhaeuser Timber Compamy were proceeding with a careful enalysis of the manufacturing end of the industry in anticipation of their future ventures in this aspect of the business. In 1902 Weyerhaeuser purchased the assets of the Bell-Nelson Mill Company of Everett, Washington, for the expressed purpose of using it as a pilot manufacturing unit. 3 With this small mill the company was able to gain valuable information on logging and manufacturing methods and costs. With this information they were later able to plan their manufacturing units with with the most efficiency possible. In doing so, Weyerhaeuser was thus able to bypass many of the manufacturing problems which plagued its competitors. For instance, the initial operation at Everett brought to light the problem of inefficiency in trying to cut the varied species of the Pacific Northwest forests. In addition to the Douglas Fir, there were other species of commercial value including Western Red Cedar, West Coast Hemlock, and Sitka Spruce. All were in demand by 1910 and were worth the effort to mill. However, the various species were not innerchangeable in the production flow of a mill due to their different characteristics, varied sizes, and the end products made from each wood. On the strength of their studies at the Everett mill, Weyerhaeuser's leaders planned many of their future mill sites to include not one sawmill, but two or even three mills, each cutting a different species or a different size of $\log$. The resulting efficiency in production justified 
the experiment. ${ }^{4}$ This concept and many other manufacturing innovations were the result of the Everett project.

Also, with this mill Weyerhaeuser was able to make a careful study of the marketing phase of the business. Everett was a station on the recently completed Great Northern Railroad, and for the first decade or so of its existence Weyerhaeuser Timber Company was able to see the exact possibilities of the new rail trade. Questions concerning such things as the acceptability of the western species in the eastern markets, the best product lines, and prices were all answered to a large degree as the Everett mill offered most of its modest output to the rail market. This extensive market survey gave the Weyerhaeuser officials additional information which allowed them to build mills which could and would concentrate on the production of certain lumber items at the expense of the full product line..$^{5}$. Thus, Weyerhaeuser was eventually able to coordinate their various mills so that the company was not only adequately covering the demands of the market but also making almost full

4Weyerhaeuser's largest mill site was built at Longview, Washington, and included three separate sawnills involved in lumber production. Mill \#1 has cut large, old growth Douglas Fir exclusively for the past forty years. Mill \#2 cuts the smaller, second growth Douglas Fir and all hemlock sent to the mill. Mill \#3 cuts only cedar and is the smallest of the three mills since not only is the cedar production the. smallest but also the cedar logs seldom exceed sixteen feet in length. Weyerhaeuser's Longview operation also has a separate milling facility for cutting hardwoods, such as red alder and maple, but this is of minor importance compared with the softwood lumber business of the mill.

5 For instance, although a large Weyerhaeuser mill, such as longview, would be producing the full product line of the company, a smaller mill, such as the Weyerhaeuser plant at Enumclaw, Washington, could take complete advantage of the smaller timber in that area and produce primarily dimension lumber, i.e., $2 \times 4^{\prime}$ s through $2 \times 12^{\prime} s$. The company would thereby be servicing not only the entire demand of the market but would also have a greater quantity of the items most in demand. 
use of its timber resource. It was a masterful bit of planning which in the long run paid the firm handsome rewards which more than offset any short term losses which it may have incurred because of the seeming hesitancy of the company to enter wholeheartedly into the manufact. uring phase of the Pacific Northwest lumber business.

By 1914 the consensus among the company's management was that the time had finally come when further delay of large scale manufacture of lumber would not be wise. Several things led it to this decision. Since the original large timberland purchase in 1900 the Weyerhaeuser people had felt a growing commitment to the railroads in general and to the Northern Pacific Railroad in particular to provide the east bound lumber shipments which the railroads so desired. With Weyerhaeuser by far the largest timberland owner among the lumber concerns on the Coast, the railroads unrelentingly applied pressure on the Tacoma based concern to start producing lumber, pointing out the fact that the primary reason that allowed Weyerhaeuser to accumulate so vast a domain in the first place was that the railroads were willing to relinquish their abundant timberland holdings at bargain prices in order to generate the east bound freight traffic which they so desparately needed to insure the success of their transcontinental lines. Although these timberland transactions were strictiy business deals to Weyerhaeuser and as such carried no specific commitment to the railroads to produce lumber, the Weyerhaeuser Timber Company did feel at least a moral obligation to help the railroads. 6 The original friendship between James Hill and Frederick Weyerhaeuser still prevailed, and the leaders of the various

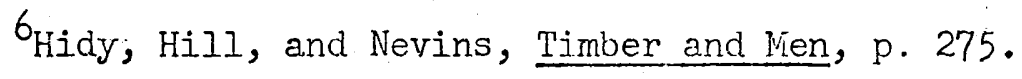


companies could see the wisdom of cooperation.

In addition to this factor, the Weyerhaeuser group more than any other lumbering firm in the region could see the great marketing possibilities offered by the combination of the continued demand for lumber in the Midwest and of the greatly reduced freight rates on Iumber. Holding the best and the most timber in the nation in their new forest lands, it is logical to assume that Weyerhaeuser could produce the most lumber in the industry if they ever decided to inaugurate manufacturing on a major scale. By 1910 several of the directors of the firm felt that time was running out to cash in on the freight rates then offered by the railroads. As has already been pointed out, these low rates were originally intended to be only temporary, to be readjusted at the discretion of the railroads. These Weyerhaeuser officials wanted the company to expand its manufacturing facilities immediately in order to take advantage of these rates and trus gain a foothold in the Midwest rail market. 7 . If

7 The size and importance of the Midwest lumber market can not be overestimated in any study of either the lumbering business of the Upper Midwest or that of the Pacific Northwest. Frederick Weyerhaeuser himself once admitted that he would rather have the State of Iowa's lumber business than that of any other three states combined (Stewart H. Holbrook, Story of American Railroads (New York: Crown, 1947), p. 182.). Although this was probably an exaggeration, the following lumber consumption statistics of various states over the years do reveal the importance of the midwestern states to the early lumbermen. In 1915 Iowa received $3.89 \%$ and Illinois received $7.91 \%$ of all softwood lumber shipments in the nation (U.S., Department of Agriculture, The Distribution of Softwood Lumber in the Middle West (Washington: U.S. Government Printing Office, 1917), p. 95.).

In 1935 Iowa received a tremendous $13,9 \%$ of all lumber shipped from the Douglas Fir region in the Pacific Northwest (West Coast Lumber Association, West Coast Lumber Facts (Seattle; Jest Coast Lumber Association, 1936), p. 9.), During the past thirty years the exodus of the midwestern farmer for the urban areas and the tendency of the remaining farmers to expand their land holdings while at the same time reducing their buildings have combined to curtail drastically the once insatiable demand for lumber of the Midwest in general and the midwestern 
the Weyerhaeuser Timber Company was ever to grow in manufacturing to the size needed to best utilize its vast timber holdings, the second decade of the twentieth century appeared to be the best time to begin the project.

Closely related to the opening of the rail market of the Midwest as a major factor in the decision of Weyerhaeuser to expand its manufacturing was the anticipated opening of the Panama Canal. Completed in 1914, the Canal opened the door to great possibilities to expand cargo shipments of lumber from the Pacific Northwest to the large metropolitan centers along the East Coast. At first these new cargo opportunities represented another reason why Weyerhaeuser should expand into lumber manufacturing on the vest coast. The more markets available, the greater the possibility of developing a successful, large lumbering operation. In time, this cargo market along the East Coest which resulted from the Panama Canal became so Iucrative for Weyerhaeuser that

farmers in particular. The following figures from the Statistical Yearbook - 1963 of the Western Wood Products Association (Portland: Western Wood Products Association, 1964, p. 12.) compare the leading states receiving shipments of lumber from the Douglas Fir region with Iowa and Illinois during the early 1960's:

$\begin{array}{lllll} & 1960 & 1961 & 1962 & 1963 \\ \text { California } & 8.6 \% & 10.1 \% & 8.9 \% & 9.8 \% \\ \text { Illinois } & 3.6 \% & 3.8 \% & 3.6 \% & 3.2 \% \\ \text { Iowa } & 2.7 \% & 2.4 \% & 1.9 \% & 1.6 \% \\ \text { Oregon } & 7.9 \% & 6.8 \% & 7.6 \% & 8.1 \% \\ \text { Texas } & 4.5 \% & 5.2 \% & 5.0 \% & 4.5 \% \\ \text { Washingtion } & 8.6 \% & 8.6 \% & 10.0 \% & 9.9 \%\end{array}$


they developed their own steamship company whose freighters delivered Weyerhaeuser lurber from the Weyerhaeuser mill in Washington and Oregon to the Weyerhaeuser remanufacturing plants and distribution centers along the East Coast.

Another very positive factor in determining the Weyerhaeuser Timber Company's ultimate decision to plunge deeply into manufacturing was the simple fact that their original pilot mill at Everett was proving that manufacturing West Coast lumber was a sound policy. ${ }^{8}$ Not only was this mill discovering new, efficient methods of lumber manufacturing in the areas of sawing, drying, milling, and shipping but:as important was the fact that the Everett operation showed an encouraging sales. growth along with a corresponding growth in production between the years of 1902 to 1913, as seen in Table 7 on the following page. Even if the company had decided to forego large scale manufacturing operations, they would have had to at least expand the Everett mill to handle the increase in its business.

Finally, the directors of Weyerhaeuser had reached the conclum. sion that something dramatic should take place to halt once and for all the mounting public criticism of the Weyerhaeuser Timber Company. As the years passed and weyerhaeuser added to its immense timber domain in the Pacific Northwest without developing its manufacturing phase to a corresponding level, the American public grew more and more fearful that the company had no other intention but to hold the timber until the market was favorable and then sell it at great profit. The muckrakers, such as Gustavus Myers; were quick to reveal the supposed 
situation to the public in rather one-sided exposes.9 However, public opinion against the large lumber firms in the West was also being shaped by the much more impartial reports, such as the aforementioned Bureau of Corporations' report of 1914, which offered concrete facts to substantiate the theory that the largest holders of timber were cutting very little of it. The implication was that these "timber barons" were intending to hold the timber as long as possible in order to gain the vast profits which would certainly accrue with the continued growth of the country.

TABIE 7

LUMBER PRODUCTION OF

THE WEYARHAEUSER TIMBHIR COMPANY, $1902-1913^{10}$

Production

Sales

(Millions of bd. ft.) (Gross amount)

1902

27

$\$ 308,000$

1903

19

286,000

1904

37

403,000

1905

39

488,000

1906

40

691,000

1907

40

744,000

1908

29

406,000

1909

48

724,000

1910

50

803,000

1911

61

814,000

MMyers, History of the Great American Fortunes, pp. 689-91. 10 Hidy, Hill, and Nevins, Timber and Nen, pp. 594 and 648. 
TABLE 7 - Continued

$\begin{array}{cc}\begin{array}{c}\text { Production } \\ \text { (Millions of bd. ft.) }\end{array} & \begin{array}{c}\text { Sales } \\ \text { (Gross amount) }\end{array} \\ 70 & \$ 1,007,000 \\ 76 & 1,150,000\end{array}$

As if these accusations were not enough, the mere size of the Weyerhaeuser Timber Company made it extremely vulnerable to public criticism from many other directions as well. Its great size when compared to other firms in the region made Weyerhaeuser the most likely scapegoat upon which the public could vent its ire in reaction to such things as the negative fluctuations of the area's econorny, labor problems, forest fires, and improper conscrvation practices. By 1914 these pressures on the Weyerhaeuser Timber Company were becoming so great that a decision on company manufacturing policy could be postponed no longer. This factor coupled with the company's obligation to the railroads, the great potential of the Midwest lumber market, the new sales possibilities offered by the opening of the Panama Canal, and the success of the Everett experimental mill all combined to tip the company's hand in favor of large scale manufacture of lumber. The decision was made, and in May, 1914 work was begun on a huge, all-electric sawmill adjoining the existing original mill at Everett, Washington.

With the completion of the Everett $B$ mill in 1915 and with the opening of the new mill at Snoqualmie Falls, Washington, two years later, the Weyerhaeuser Timber Company was definitely committed to a major manufacturing effort. From this start the company continued to add other milling units in western Washington and Oregon until it had eleven separ- 
ate mill sites producing lumber. These range in size from the Cottage Grove, Oregon mill with an annual capacity of 60 million board feet of lumber to the vast. Longview, Washington, operation which is capable of producing approximately 310 million board feet of lumber a year. In addition to these mills which are owned and operated by the Weyerhaeuser Company, the individual members of the Weyerheeuser family and their associates within the lumber syndicate have long held controlling interests in Potlatch Forests, Inc. and the Boise-Cascade Corporation. 11 Both of these Idaho based companies have dominated the Iumber scene in their respective regions for many years. Potlatch Forests controls the country's last virgin stand of white pine in northern Idaho, while Boise-Cascade has substantial holdings in southern Idaho, Washington, and Oregon.

In addition to this great growth in and their dominance over the lumber industry of the entire Pacific Northwest, the Weyerhaeuser group has also extended its holdings in other fields related to timber processing, such as plywood manufacture and paper production. The firm's two recent mergers, one with Roddis Plywood Corporation in 1960 and the other with Kieckfefer Eddy Paper Company in 1957, added extensive facilities to Weyerhaeuser's original holdings in these product areas. Although not directly related with lumber production, the company's diversification in its product line has greatly added to its ability to make full use of its timber resource, thus adding even more strength to its position of leadership in the lumber industry.

However, the extent of Weyerhaeuser's particular growth and success

${ }^{11}$ The corporate name was changed in 1959 from the Weyerhaeuser Timber Company to the Weyerhaeuser Company. 
in the Pacific Northwest is not the prime consideration of this paper. of greater relevance to the theme is an examination of the reasons why the big lumber producers, such as Weyerhaeuser, were able to succeed and grow when others remained small. As has already been mentioned, the key factor in the success or failure of any lumber manufacturer is the availability of accessible timber. Many companies, such as Pope and Talbot and Long-Bell, showed momentary signs of permanence and industrial dominance, only to eventually have their growth stifled because of a lack of sufficient timber reserves. An analysis of their failings would reveal the fact that they originally placed their prime emphasis on the development of manufacturing facilities at the expense of acquiring the necessary timber reserves needed to support a large manufacturing operation on a permanent basis. In comparison, the lumber companies in the Pacific Northwest, such as Weyerhaeuser, who placed initial emphasis on the acquisition of large timber reserves and then turned to the development of manufacturing were the firms that eventually gained a position of permanent leadership in the lumber industry of the region.

However, there was more to success than just acquiring timber reserves. What was done with these timberlands after their acquisition was also an important factor in the future of a lumber company. Again, using the methods of the Weyerhaeuser Timber Company as an example, it is obvious that the period of time between the initial timberland purchases in the West and the establishment of major manufacturing sites was not spent in idle ways. From 1900 to 1915 and even in the years which followed, weyerhaeuser actively persued a plan of organizing their 
forest holdings in such a way that when they did move into manufacturing they would have almost total control over the timber of a given area.

Blocking up their extensive and widespread holdings which were arranged in a checker board pattern over western Washignton and Oregon due to the nature of the original land grants, the Weyerhaeuser firm traded odd sections of land for even ones with the government and the other private land holders until it either had complete ownership of all sections, both odd and even, within a given forest area or until it at least owned enough sections so as to actually have control over the timber in the immediate vicinity which the company did not own. This latter situation often occurred when Weyerhaeuser was able to completeIy enclose the area of a competitor's land with their (Weyerhaeuser's) land, thus in effect negating the ownership of the enclosed land. According to the 1914 government study of the Pacific Northwest lumber industry,

The Weyerhaeuser Timber Co. in western Washingtion .. . bought large areas of Northern Pacific lands . . all in such a way as to secure not only actual ownership of a very large proportion of the timberland in the regions where their holding lie, but a very considerable measure of additional power by control.

In western Washington the Weyerhaeuser Timber Co. . . is said to practically control the timber situation throughout large stretches of country - for example in the southern part of Pacific County, or in Lewis County. 12

Not only did Weyerhaeuser trade for better land arrangements, but contrary to the belief of many, the company actually sold considerable blocks of its timberland in order to consolidate its holdings. However, it was seldom if ever done unless weyerhaeuser could use the sale to its 
advantage either in respect to profit or to generate a larger, better situated timberland purchase. The authors of Timber and Mien relate that George Long, the Weyerhaeuser firm's first general manager, was always ready and willing to sell company lands that did not fit into the company's plans, particularly when these sales would facilitate buying in more advantageous places. By 1904 Long had actually sold a total of 35,000 acres of either timberland or timber rights.

These transactions effected a double effect. They blunted the edge of popular suspicion of the Weyerhaeuser interests (i.e., that Weyerhaeuser was a timber monoply), and they also made a fair. profit. The 35,000 acres . . fetched $\$ 940,000$, the company making what seemed a large profit; and although the margin was less than it appeared - for interest, taxes, and management costs had to be considered - it was liberal.13

Assuming that much if not all of this acreage was probably part of the. 1900 land purchase from the Northern Pacific Railroad which originally cost the company. $\$ 6$ an acre, the gross profit would be $\$ 730,000$ ! Considering also the fact that these were the days before income taxes, the authors of Timber and Men seem to be rather conservative in their estimate of the net profit.

The effect of all these dealing's was that Weyerhaeuser soon found itself in the position whereby it could actually control the major portion of the lumber industry in a given area, even to the extent of freezing out its competition completely if, the situation so dictated. As one early competitor of Weyerhaeuser in the Pacific Northwest found out to his dismay, "Weyerhaeuser . - absolutely controls all the timberland in this county (Pacific County, Washington). They are a hard company to deal with. You can not cross their land wi.thout paying them 
about what the land itself is worth. " 114

These variations of Weyerhaeuser's version of economic Dar'winism are most apparent in a study of the relationship between the firm and the Long-Bell interests in the Longview, Washington, area. In fact, the Weyerhaeuser vs. Long-Bell struggle for supremacy in Longview was typical of the emerging lumber giants in the Pacific Northwest and holds within it and its results the real reasons for the growth and success of the few large lumbering concerns which survived this and similar struggles.

In the early years of this century Robert A. Long controlled a large lumber business in the South with headquarters in Kansas City, Missouri.15 By 1920 . Long began to look to the West as his company's resources in the South showed definite signs of depletion. However, R.A. Long's idea of an operation on the West Coast was unique in that he wanted Iong-Bell Lumber Company to create the ideal industrial unit which would include not only the timberlands and millsite but also the entire town where the mill was to be located. This complex was to be set up on a permanent economic basis, and everything including the townsite, was to be completely planned in advance. After extensive surveys which studied the timber resources, the geographical and geological possibilities, and also the general economic potential of each area under consideration, Long chose the site of the present town of Iongview, Washington, as the best possible location for his dream city. After purchasing what were considered to be sufficient timberlands in

14 The Lumber Industry, II, p. 14 .

15 Robert A. Long was no relation to Weyerhaeuser's George S. Long. 
the Mit. St. Helens area, Long-Bell began in 1923 to lay out the town of Longview. 16 R.A. Long's vision called for an eventual population of 100,000, and so the plans were made accordingly with extra wide streets, large hotels, and all of the other necessary facilities needed to support this number of inhabitants. Unlike many of his contemporaries in the lumber business, R.A. Long did not wish for this new operation to become a typical company town, completely controlled by Long-Bell and completely dependent upon the economic fortunes of the local. Long-Bell mill. In order to give the town permanence, Long knew that he must interest other Iumbermen and even other industries in the advantages of locating in Longview. With this in mind he naturally turned to the Weyerhaeuser Timber Company, the largest timberland holder in the area, as a prime prospect. Weyerhaeuser, after initial studies were completed, decided to erect a mill at Longview in order to take advantage of their vast Mt. St. Helens' timber holdings which amounted to nearly thirty billion board feet of prime timber. By the time weyerhaeuser made their decision, long-Bell had erected what was considered to be the largest sawmill in the world, capable of cutting 1,000,000 feet per day. By 1929 Weyerhaeuser had built their mill complex, which also was capable of producing 1,000,000 feet per day. By 1958 the Iong-Bell mill was completely closed down, the immense lumber storage sheds being used for the storage of wheat and other grains. Meanwhile, the Weyerhaeuser mill less than a mile down the river continues to grow and shows all the signs

16Arriving on the Coast too late to get in on the bargain timber sales of the railroads, Long-Bell made their first timberland purchases in 1920 for their purposed Longview venture. A total of 70,000 acres was purchased from the Weyerhaeuser Timber Company in the forests surrounding Mt. St. Helens (McClellan, Longview, p. 6.). 
of the permanence which originally belonged to the Long-Bell mill.

How one giant could die while the other survived and continues to grow is an interesting story. There are probably two primary reasons why this happened., First, for all of his vision and business ability R.A. Long failed to surround himself with enough men of ability to carry on the company's earlier successes. The higher levels of the management group brought out to the West from Kansas City were the equal of any group in the business, including the Weyerhaeuser people. However, Long and his associates did not continue to bring capable men into the jobs of responsibility, and also these original company leaders, including such men as Wesley Vandercook, W.H. Ryder, S.M. Morris, and R.A. Iong himself, failed to produce sufficient numbers of male offspring capable of carrying on the company's traditions. As a result, when the original leadership core began to age and pass from the scene a vacuum was created, and Long-Bell was left without proper leadership. Weyerhaeuser, on the other hand, not only continued to bring in good men from the outside, but there was always a good supply of sons to fill the shoes of their fathers and uncles. As has been noted previously, Frederick Weyerhaeuser himself had four very capable sons, each one becoming in time a leader in at Ieast one segement of the organization. Today, the fourth generation of some of the other original partners are most active in the management of the Weyerhaeuser Company. This positive, progressive leadership of Weyerhaeuser was a definite reason for its Longview success, and LongBell's lack of this type of management was a prime reason for its eventual failure at the same location.

The second factor in the decline of Long-Bell was the short sighted-: 
ness of the firm in their purchases of timberland. Their troubles actually began when they were forced to buy their original timberland for their Longview plant from Weyerhaeuser at the latter firm's terms. By 1930 Long-Bell began to realize that not only had they made many of their timberland purchases at top market prices and thus over-extended themselves, but also much of the land they had acquired was situated in areas where access to it was controlled by Weyerhaeuser. Thus, LongBell was at the mercy of their chief competitor. Weyerhaeuser was quick to realize these conditions and merely had to sit back and wait for Long-Bell to dry up both financially and in respect to its raw mate- .. rial supply. In regard to the land which Long-Bell had bought at top market prices, this in part eventually was resold to weyerhaeuser at bargain prices due to the former's need for operating capital. ${ }^{17}$ other sections of Long-Bell land in the St. Helens area were completely surrounded by sections belonging to Weyerhaeuser. When Long-Bell inquired as to the possibility of gaining right-of-way through the Weyerhaeuser property, it was usually refused. Weyerhaeuser explained their refusals by reasoning that they must have sole control over which of their lands were to be opened for logging, otherwise it would destroy their grand scheme for total dollar realization of their timber. In other words, with some 500,000 acres of timber in the area, Weyerhaeuser could easily cut in another sector and thus starve Long-Bell out. In such instances, Long-Bell could do nothing but sell out to Weyerhaeuser at the latter's price. By 1948 Long-Bell's original holdings in south-

17 Weyerhaeuser often bought the land for less than Long-Bell originally paid for it (Hidy, Hill, and Nevins, Timber and Kien, pp. 278-79. 
western Washington were largely depleted, and the firm was purchasing the greater percentage of its log supply from independent loggers. By 1957 the price of these logs on the open market was too prohibitive for profitable lumber manufacturing, and consequently long-Bell was forced to close its Longview mill completely. ${ }^{18}$ Meanwhile, Weyerhaeuser continues to log its "ten cents a thousand" logs!

The passing of Long-Bell's hugh operation in southwestern Washington is not unique. It has happened many times in the past to all types and sizes of lumber operations as they struggled to gain a foothold in the Pacific Northwest lumber industry and strove to achieve a position of dominance and a degree of permanence. As happened in other lumbering regions, only the strong won any major share of power. Often they employed rather ruthless means to achieve their end goals. However, in the Pacific Northwest these goals of power and permanence had an added meaning and were worth the added effort for those few fortunate lumbermen who were able to persevere. The added significance of leadership in the West was that it would also mean permanent leadership in the nationwide lumber industry for all the years to come. This was the final stand of the lumber industry, and those who had the foresight to grasp this fact moved rapidly once the railroads had opened the region. They correctly foresaw that the primary key to greatness and permanence was the acquisition of sufficient timber reserves and their proper management, and they acted accordingly. 


\section{CHAPTER VI}

With the ascendency of the few large lumber producers to a position of leadership in the rapidly expanding lumber industry of the Pacific Northwest, the basic patterns for modern Iumbering began to develop. Naturally, many of the customs and methods of the industry's earlier years were retained, but the circumstances dictated certain radical changes in lumbering philosophy which in effect have greatly altered the industry's development since the turn of the century. Most, if not all, of these changes can be traced to the integration and concentration of industrial power into the hands of the large timber processing firms of the Pacific Northwest.

To be sure, the growth of these hugh Iumber manufacturers did not signal the end of the small, independent lumberman. Although the tendency is often to think of such firms as Weyerhaeuser, Simpson, Pot latch Forests, Boise Cascade, and Georgia-Pacific as being the giants of the industry, they actually control only a relatively small part of the total lumber business. Recent figures show that in 1964 there were nearly 33,000 separate lumber manufacturing establishments in the entire United States, ranging in size from Weyerhaeuser to the small "gypo" type mill which comes and goes depending upon the prevailing lumber market.l This figure clearly points out the fact that even though the few large operators have gained control of large segements of the industry in

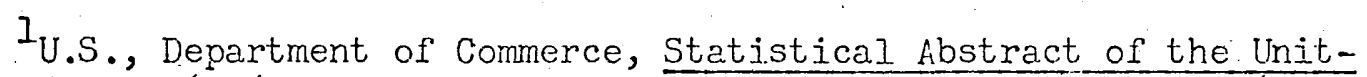
ed States - 1964 (Washington: U.S. Government Printing Office, 1964), p. 688 . 
certain locals, no lumber monopoly or even oligopoly has developed to completely dominate the industry. The very nature of the business allows for the continued existence of the small independent producers. In this respect the Iumber industry can be compared with farming. Both are engaged in using the land to grow and harvest a renewable crop. Because trees of commercial value can be grown alnost anywhere in the country and because all a man needs to become a lumberman is a saw, it is easy to see why the industry has never been able to completely eliminate the marginal operator. Much the sane is true of farming. Although the trend in recent years has been toward the large farming operation with some even suggesting that farming eventually will be done entirely on a large corporate type basis, the fact remains that as long as men are independent and like to work the soil there will probably be the small marginal operator in that industry, too.

In lumbering these smaller independent operators have traditionally been the source of many of the major problems of the industry. Lack of conservation of the resource, instability of the lumber market, lack of uniformity of manufacture, and other adverse aspects characteristic of the industry throughout its long history can, in a great many instances, be traced to the small independent lumberman. Even today after a half century of relative stability in regard to the organization of the industry, the smaller lumber firms are by their very nature rather unstable, short term operations. These firms continue to remain strictly lumber producers, lacking the capital and/or the inclination to diversify their product line to include timber products other than lumber. As a result, their problems are multiplied. Extremely sensitive to the 
whims of the lumber market, the small independents without a sufficient reserve of low priced timber must continually gamble on outside log and timber purchases, hoping to buy their raw material cheaply and to sell their lumber product at a good profit. Few of the smaller operators possess this ability to analyze the market accurately, and even then they find themselves at a distinct disadvantage. The larger firms with their greater financial resources are able to consistently out-bid the small firms for tracts of timber stumpage offered for sale by the state and federal governments. One study made in 1960 revealed the following breakdown of where lumber mills in western Oregon were acquiring their respective log supplies:

\section{TABIE 8}

\section{TIMBER SOURCES OF
WESTERN OREGON SAWMILIS $-1960^{2}$}

Class A Companies (Capacity of 120,000 or more feet a day)

51\% Timber from company owned land

49\% Timber from government timber sales

Class D Companies (Capacity of 40,000 or less feet a day)

9\% Timber from government timber sales

91\% Timber from private timber sales, i.e., generally scavenger timber sales from privately owned commercial forest land.

In summarizing the situation the author states that "obviously, the companies in Class D most dependent on public timberland for their supply of raw material were able to obtain actually only a widow's mite. 3

2Franklin Y.H. Ho, Small Lumber Companies in Western Oregon (Washington: Small Business Administration, 1963), p. 5.

3. Ibid. 
The result of this situation is that the timber processed by the smaller firms is often inferior, lending itself to the manufacture of an inferior product. Unable to compete with the larger firms in respect to quality, the small independents often must sell their lumber on price alone, sometimes even "dumping" their production on the market in order to get enough money to continue their operations. The effect of this type of marketing on the stability of the lumber price structure is often quite adverse.

The effect on the small firms can have even greater consequences. Their continual emphasis on short term profit results in small profits which in turn limit the business horizons of the firms. The operations are relegated to the marginal level, and their management often reverts to the traditional "cut out and get out" policy of the industry's earlier days with all of its negative aspects of timber management and lumber manufacture. "Actually, the core of major problems (for the small lumber concerns) centers on certain institutional and managerial factors, which place smaller companies at a disadvantage in raw material procurenent and in product selling. Relatively irregular production schedules result, which, in turn, further heighten raw material procurement and product selling problems. The smaller companies, in effect, are caught up in a vicious circle (often) leading to exhaustion and extinction."14 However, to imply that there is no longer a place for the small independent operator or that their operations are entirely detrimental to the continued well-being of lumbering would be doing an injustice to this segement of the industry. The smaller firms, at least those who 
aspire to some degree of respectability and permanence, serve the good of the industry in several ways. In regard to the lumber market the emphasis on price by these firms often is a major factor in keeping the price schedules of the large lumber manufacturers in line. Singly. the small firms have little or no effect on the market, but taken collectively they can exert great pressure on the market, forcing the giants of the industry to use moderation in their attempts to raise lumber prices. 5

In the area of logging and milling many of the smaller firms are at last beginning to realize the importance of adopting and practicing sounder conservation habits. Lacking funds and large timber reserves, these firms are naturally less inclined to become involved in extensive conservation programs. However, the more progressive small mills are beginning to understand that their best chance for survival is to concentrate on those areas of production which the larger mills find unprofitable because of their size and manufacturing policies, and in doing so these smaller mills have also become active participants in the modern conservation movement. Many smaller firms have found that they can make money by concentrating on milling timber passed over by their larger competitors. These large mills often can not afford to spend their time, effort, and money in specialized thinning or salvage operations, and they have found that by contracting this work out to the small logging firms and mills, everyone can benefit. Also, by specializing in one or two particular products, such as $2 \times 4$ studs or cedar siding products, and

5 of the 32,916 separate manufacturing units in $1964,32,842$ or 99.8\% of them were lumber firms producing less than 50,000,000 board feet per year (Statistical Abstract - 1964, p. 688.). 
by selling their waste material, such as sawdust and wood chips, to the large, integrated timber processors, the small independents not only increase their profit margins, but make a substantial contribution to the concept of full utilization of the timber resource. Many of these mills have been able to tear down their waste burners as a result of their conservation efforts at the mill level, much to the approval of the general public. The significance of this enlightened effort on the part of some sma.l lumbermen is that the conservation movement now has industry-wide support.

However, in spite of their efforts the small independent firms can. never hope to approach the position of leadership and influence attained by the few giants of the lumber industry. With their e ergence at the turn of the century in the Pacific Northwest these large corporations brought to the industry those elements needed to modernize it and to help it keep pace with the advances being made in other manufacturing fields. By their very nature of organization the large firms, such as Weyerhaeuser, have revolutionized the industry by the degree to which they have integrated the various phases of their operations and by the manner in which they have diversified their manufacturing into timber product fields other than lumber. No longer can they be called lumber companies in the traditional sense of the term. Instead, the term "timber processors" better describes the total scope of their operations. All have integrated horizonally. They have become multi-mill firms in all of their product lines, scattering their related holdings over the country and even in the case of a few of these corporations, to foreign countries. Some have also expanded their operations vertically, owning and operating all phases 
of production from the processing of the raw material to the transportation involved in getting the finished product to the market, to the retail marketing of the product.

These twin drives toward integration and diversification reflect a basic change in lumbering philosophy which evolved with the emergence of the large timber processors. Through research and experimental operations, such as Weyerhaeuser's early pilot mill at Everett, Washington, the lumber giants of the twentieth century found that not only could products be made from former waste material but that there were profitable markets for these products. Once this discovery was made, the concept of full utilization of the timber resource quickly followed. Where formerly the entire industry was oriented around a policy of "cutting only the best and leaving the rest," the new industry leaders with their practice of full utilization began to eliminate such words as "waste burner" and "weed species" from their vocabulary. As has already been noted, the acceptance of this new philosophy of lumbering has grown to the point that today even many of the smaller mills are finding ways to use full utilization of their timber to better their position in the industry.

The importance of the large timber processors is further evident in the tremendous changes. which they have brought not only to the Iumbering industry itself but to the general economy as a result of their form of organization and their revolutionary philosophy. of primary importance to the lumber industry is the leadership which these few firms have brought to an industry which historically has had no real leadership. Since the early 1900 's these firms have led the crusade within the in- 
dustry to improve Iumber's image before the public. Rising above the traditional isolationism and mistrust of their smaller competitors, Weyerhaeuser and the other leaders realized the need for industrial associations which would bring standardization and uniformity to the areas of lumber manufacturing and marketing. Their willingness to relinquish part of their corporate sovereignty to such industrial groups as the West Coast Lumberman's Association and the Western Pine Association proved to be the stimulus needed to get these organizations started. The resultant effect on the industry is quite apparent. These associations through their formal grading rules and quality control efforts have brought the long sought product standardization and uniformity to the industry. The industrial advertising and other aspects of their public education program have made great advancements in building a better public image of the lumber industry and in doing so have increased the demand for Iumber.

The leadership of the large lumber companies has also been must strong in the area of research and innovation. Lacking surplus funds to promote such product development and improvement studies, the smaller lumber concerns must look to the larger organizations for any research advancements. The large companies have responded to this challenge by setting up research centers and by allocating a large portion of their yearly earnings to this phase of their operation. 6 The results of this effort are apparent in the greatly increased number of different timber products. Not only have the basic lumber items been made better, but a

6For example, Weyerhaeuser Co. currently spends approximately $\$ 5$ million annually in its research program (Information gained from a Weyerhaeuser official who wishes to remain unidentified). 
host of products unrelated to lumber have been developed. Included in these new items are the various fiber products, chemicals, and paper pulp processes which are able to produce the entire range of paper products from the finest writing papers to packaging materials which have revolutionized the packaging incustry. Initially, the efforts of the large timber processors in the areas of research and product development have been generated by the individual company's desire to improve its profits, but in the final analysis it has been the entire industry and society as a whole who have benefited, for as more forest products are developed, each serves the dual role of benefiting society and of better utilizing our forestland and its resources.

As their knowledge of the timber resource grew, so to did the awareness of these large firms in the urgent need to formulate a sound conservation policy. Their rapidiy growing operations coupled with the reality that there would be no new forests to conquer after the cutting of the Facific Northwest woods, forced the giants of the industry to take a bold stand against the industry's traditional lack of conservation. Responding to the initial efforts in conservation by the U.S. Forest Service in the first decades of the century, the larger, private lumber corporations soon became leaders in promoting the movement within the industry. This endeavor has paid handsome dividends in several respects. Inaugurating their campaigns at a time when public opinion was quite set against the private timber interests of the country, the large firms, such as Weyerhaeuser, introduced the hitherto unheard of concepts of full utilization of their timber resource and of sustained yield with its appealing tree farm aspect. Advertising their intentions and pro- 
gress in the field of conservation, often in the same popular periodicals which were attacking the private lumbermen for their lack of conservation, the industry's leaders were able to turn the tide of public opinion.

However, even if there had been no public pressure brought to bear on the lumber industry to improve its conservation policies, there would have no doubt been a strong effort made to establish a sound conservation stand. The emerging giants of the industry had too much at stake in their extensive operations to allow themselves to make the same mistakes which the industry had committed in other areas. The lessons of Maine, Michigan, Wisconsin, and Minnesota had not fallen on entirely deaf ears. The situation had been different in those earlier regions. Now, in the Pacific Northwest, it had finally come down to a basic question of a choice between conservation of the natural resource or extinction of the industry. The realization that timber and its perpetuation is the key to the industry's growth, wealth, and permanence led to the choice in favor of conservation, and with the large timber processing firms showing the way with their enlightened conservation policies both in the woods and in the mills, the lumber industry entered a new era.

Moreover, the Ieadership of the industry's giants did not fade once they began this revolution within the industry. Their ideas of full utilization and sustained yield had a greater significance than simply fulfilling the basic requirements of a sound conservation plan. They carried the added implication that these firms intended to become permanent fixtures in the economy of the Pacific Northwest in general and in 
the economy of the various mill towns in particular. It was no longer to be a case of "cut out and get out" for these large firms with the resulting depressing effect upon the region's economy. The leaders of these companies, such as R.A. Long with his vision of permanent LongBell and Weyerhaeuser operations in Longview, began placing their reliance in stability and permanence with the emphasis on a long term profit rather than on the short sighted, short term profit motives of the industry's past.

The results of these efforts on the part of the large timber processors have been as gratifying to themselves, the lumber industry, and society as have been their efforts at conservation. The stability and permanence of thése large corporations has brought a corresponding stability and permanence to the economy and social order of the Pacific Northwest and other lumbering regions where these firms have an influence. The days of the ghost towns and the migratory labor force resulting from an ever shifting Iumber industry have passed from the scene for good.?

7 Such changes did not take place immediately. Even the lumbering region of the Pacific Northwest after the advent of the large firms had its nomadic labor problems with its accompanying unrest upon the economic, social, and political levels of the region's life. The nature of the conditions within the industry in the Pacific Northwest during this transition period are revealed in the following passage taken from an article by a pro-labor writer of the period:

All of these three principal occupations of the unskilled worker of the Pacific Coast - lumber, construction work, and agriculture are periodical in their nature . . . The result of this is the existence on the coast of an immense army of unskilled or semi-skilled workers, of no fixed abode, who are forever engaged in an eternal chase for the elusive job; whose work takes them away from the towns to the hills or plains or forests, for varying periods. Forever over the great western country are they traveling, seeking this or that center of temporary activity, that they may dispose of their laborpower (Charles Ashleigh, "The Floater" as reproduced by Joyce L. Kornbluh (ed.), Rebel Voices (Ann Arbor: University of Michigan Press, 1964), p. 80. ). 
In their place have come permanent cities and towns and a work force which reflects the stability of the present industry. These communities have grown with their primary timber industry. The integration and diversification of the large timber firms have greatly added to the economic soundness of these communities and the general region, giving them a future quite unlike that of their historical counterparts in the East and Upper Nidwest.

In retrospect, the emergence of the large timber processing corporations marked a definite turning point in the history of the lumber industry. The industry brought some two hundred years of lumbering tradition with it to the western forests only to find that many of the old ways which had worked so well in other regions would no longer suffice. If the industry was to survive as a vital part of the nation's econony, something drastic had to be done to change the industry's course. It was left to a handful of lumbermen to lead the entire lumber industry out of the woods. Combining their foresight, their finances, their abilities, and their courage, they were able to assess the strengths and the weaknesses of the past, and they then laid the foundations upon which a new era of economic growth could be built. 
APPENDIX 


\section{TABLE 9}

TIMBER HOLDINGS IN THE WEST OF THE

SOUTHERN PACIFIC RAIIROAD - $1912^{2}$

Oregon
California
Total

Timberlands

(acres)

Timber

(billion feet)

$1,907,236$

70.5

$\underline{1,934,580} \quad \underline{35.1}$

$3,841,816$

105.6

The Lumber Industry, II, pp. 5-6. 
TABLE 10

TIMBER HOLDINGS IN THE WEST OF THE

WEYEPHAEUSER TIMBER CO. - $1912^{\mathrm{a}}$

Timberlands

Timber

(acres)

(billion feet)

Washington

$1,515,932$

76.9

Oregon

380,599

18.7

California

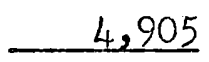

.1.

Total

$1,901,436$

95.7

a The Lumber Industry, II, pp. 5-6. The figures in Table 10 include just the Weyerhaeuser Timber Co. and those subsidiary companies directly controlled by it at the tine. 
TABIE 11

TOTAI WEYERHAEUSER SYNDICATE TIMBER

HOLDINGS IN THE ENTIRE NATION $-1912^{\mathrm{a}}$

Pacific

(Figures in billion feet)

Northwest

Southern

Iake

Pine Area States

Total

Weyerhaeuser

Timber Co.

95.7

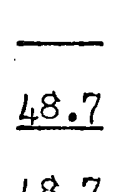

$-$

95.7

$\operatorname{other}^{*}$

$\underline{132.8}$

$\underline{14.7} \quad \underline{196.2}$

228.5

14.7

291.9

*Consists of other companies in which Weyerhaeuser family members and/or other members of the syndicate held interests.

aThe Lumber Industry; II, pp. 5-6. 
TABLE 12

TIMBER HOIDINGS IN THE WEST OF THE

NORTHERN PACIFIC RAIIROAD - $1909^{a}$

\begin{tabular}{|c|c|c|c|c|c|c|}
\hline \multirow{2}{*}{. } & \multicolumn{2}{|c|}{ Patented* } & \multicolumn{2}{|c|}{ Unpatented* } & \multicolumn{2}{|c|}{ Total } \\
\hline & $\begin{array}{c}\text { Timberland } \\
\text { (acres) }\end{array}$ & $\begin{array}{c}\text { Timber } \\
\text { (billion feet) }\end{array}$ & $\begin{array}{l}\text { Timberland } \\
\text { (acres) }\end{array}$ & $\begin{array}{l}\text { Timber } \\
\text { lition feet) }\end{array}$ & $\begin{array}{l}\text { Timberland } \\
\text { (acres) }\end{array}$ & $\begin{array}{l}\text { Timber } \\
\text { llion feet }\end{array}$ \\
\hline Washington & 486,877 & 10.4 & $1,015,427$ & 14.8 & $1,502,304$ & 25.2 \\
\hline Idaho & 182,505 & 2.7 & 141,625 & 1.8 & 324,130 & 4.5 \\
\hline Montana & 480,486 & 2.6 & 394,543 & 2.2 & $1,152,589$ & 6.5 \\
\hline Total & $1,149,868$ & 15.7 & $1,551,595$ & 18.8 & $2,979,023$ & 36.2 \\
\hline $\begin{array}{l}\text { *Pate } \\
\text { actu } \\
\text { the } \\
\text { Land } \\
\text { the }\end{array}$ & $\begin{array}{l}\text { ed land ref } \\
\text { ownership } \\
\text { rthern Paci. } \\
\text { ffice for t } \\
\text { ilroad had }\end{array}$ & $\begin{array}{l}\text { ers to that por } \\
\text { title. Unpaten } \\
\text { fic had an opti } \\
\text { itle of actual } \\
\text { actually been b }\end{array}$ & $\begin{array}{l}\text { of the lan } \\
\text { land refers } \\
\text { a but as of } \\
\text { rship. Nor }\end{array}$ & $\begin{array}{l}\text { nt for } w \\
\text { hat port } \\
\text { date (I } \\
\text { this ac }\end{array}$ & $\begin{array}{l}\text { Northerm } \\
\text { the land gr } \\
\text { d not filed } \\
\text { uld not be }\end{array}$ & $\begin{array}{l}\text { ific had } \\
\text { for which } \\
\text { th the } \\
\text { en until }\end{array}$ \\
\hline
\end{tabular}

Land Office for title of actual ownership. Normally this action could not be taken until

the railroad had actually been built along the right-of-way in question. 
TABLE 13

IFADING STATES IN THE PRODUCTION

OF WHITE PINE LUMBER, 1869 - $1965^{\circ}$

(All quantities per 1,000 board foot measure)

\begin{tabular}{|c|c|c|c|c|c|}
\hline & $1869^{*}$ & $1879^{*}$ & $1889^{*}$ & 1899 & 1910 \\
\hline Naine & 450,000 & 332,000 & 300,000 & 214,865 & 272,509 \\
\hline New York & 721,000 & 463,000 & 223,000 & 117,237 & 70,990 \\
\hline Pennsylvania & 780,000 & 620,000 & 453,000 & 225,047 & 82,116 \\
\hline Michigan & $1,714,000$ & $3,550,000$ & $3,498,000$ & $1,234,51.4$ & 128,400 \\
\hline Wisconsin & 783,000 & $1,112,000$ & $2,451,000$ & $2,340,628$ & 577,674 \\
\hline Minnesota & 230,000 & 524,000 & $1,209,000$ & $2,157,866$ & $1,280,239$ \\
\hline \multirow[t]{2}{*}{ Idaho } & $-\cdots-\cdots$ & $-\infty-\infty$ & 3,000 & 1,990 & 232,442 \\
\hline & $\underline{1920}$ & 1930 & 1940 & 1945 & 1965 \\
\hline Miaine & 165,102 & 110,834 & 131,294 & 263,149 & \\
\hline New York & 66,311 & 10,280 & 18,644 & 100,429 & \\
\hline Pennsylvania & 29,004 & 10,779 & 12,260 & 39,030 & \\
\hline Michigan & 36,186 & $1.9,239$ & 24,976 & $31,, 514$ & \\
\hline Wisconsin & 88,976 & 42,153 & 42,706 & 93,792 & \\
\hline Minnes ota & 429,210 & 144,391 & 79,863 & 45,603 & - \\
\hline Idaho & 261,251 & 432,438 & 421,538 & 220,321 & $300,944^{b}$ \\
\hline
\end{tabular}

*Based on census reports which gave quantities for states but not for kinds (species) of wood.

**igures not available by species by state.

$a_{U . S}$, Department of Agriculture, Lumber Production in the United States: 1799 - 1946 (Washington: U.S. Government Printing Office, 1947), p. 217.

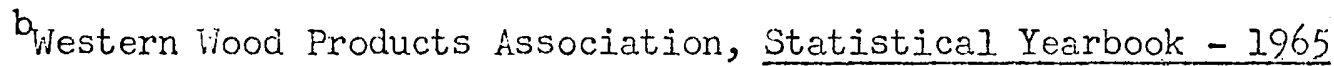
(Portland: Western Wood Products Association, 1965), p. S-8. 
TABIE 14

IEADING STATES IN THE PRODUCTION

OF DOUGIAS FIR LLMBER, 1869-1965

(AII quantities per I,000 board foot measure)

$\begin{array}{lccccccc} & 1869 * & 1879 * & 1889^{*} & 1899 & 1910 & 1920 & 1930 \\ \text { Oregon } & 54,000 & 130,000 & 301,000 & 501,237 & 1,714,462 & 2,347,368 & 2,359,062 \\ \text { Washingtion } & 107,000 & 124,000 & 847,000 & 1,152,672 & 3,259,546 & 4,275,017 & 3,826,066\end{array}$

\begin{tabular}{|c|c|c|c|c|c|c|}
\hline & $\underline{1940}$ & 1945 & $1950^{\mathrm{b}}$ & $1955^{\mathrm{b}}$ & $1960^{\mathrm{b}}$. & $1965^{\mathrm{b}}$ \\
\hline Oregon & $3,251,187$ & $3,501,773$ & $6,340,106$ & $5,856,331$ & $4,471,491$ & $4,107,710$ \\
\hline Washington & $3,509,266$ & $2,128,029$ & $2,040,312$ & $1,645,377$ & $1,153,007$ & 1,12 \\
\hline
\end{tabular}

*Based on census reports which gave quantities for states but not for kinds (species) of wood.

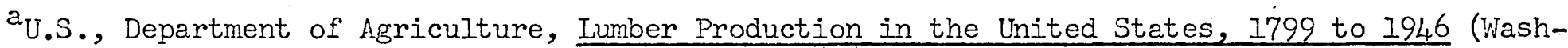
ington: U.S. Government Printing Office, 1947), pp. 196-97.

$b_{\text {Western }}$ food Products $\Lambda$ ssociation, Statistical Yearbook - 1965 (Portland: Western Wood Products Association, 1965), p.S-5. 
BIBIIOGRAPHY 
Books

Andrew, Ralph W. and Kinsey, Darius. This Was Logging. Seattle: Superior Publishing Co., 1954, pp. 157.

A pictorial history of early logging in the Pacific Northwest, this book served as a resource for the verification of logging practices in this particular region during the early years of this century.

Brissenden, P.F. The IW: : A Study of American Syndicalism. New York: Columbia University Press, 1919, pp.438.

This study of the labor unrest in the Pacific Northwest was of value since it was written at the height of the problem. The author's comments give a perspective on the labor sj.tuation of that era not gained through studying more recent books on the subject.

Brown, Nelson Courtlandt. Logging-Principles and Practices. New York: Wiley and Sons, Inc., 1934, pp.284.

This work was used principally to verify the use of various logging methods and customs accepted a.s standard by the industry of the Pacific Northwest during the first half of this century.

Cochran, T.C. and Miller, W. Age of Enterprise New York: Miackillan, 1952, pp. 396.

A general commentary and analysis of the period of American history following the Civil War, this book was valuable primarily for its insight concerning the effect of the development of communications on the growth of big business in the United States.

Coman, E.T. and Gibbs, Helen M. Time, Tide, and Timber. Stanford: Stanford University Press, 1949, pp. 480.

A rather stereotyped corporate history, this work nonetheless was valuable in pointing out conditions both economic and social in the Pacific Northwest prior to the birth of the region's commercial lumber industry and during the early years of its existence. It traces the development of the firm of Pope and Talbot throughout its entire history up to 1949 with particular emphasis on its Pacific Northwest operations. The book provided a valuable comparison between Pope and Talbot as one of the early leaders of the region's lumber industry and the later giants, such as Weyerhaeuser.

Engstrom, Emil. The Vanishing Logger. New York: Vantage Press, 1956, pp. 135.

A brief history of the logging industry based on the author's personal experiences, this work was a bit too general and too superficial to be of much direct worth to this paper.

Faulkner, Harold U. The Decline of Laissez Faire. New York: Rinehart \& Co., 1951, pp. 433 .

Faulkner's book was used primarily for the author's insights into 
the reasons. behind the rise of big business in the United States.

Ginger, Ray. Altgeld's America. Chicago: Funk and Wagnalls, 1958, pp. 386.

This analysis of the nature of liberal protest in the late 1800's was read primarily for general knowledge. Although not dealing in any way with the lumber industry, the author's comments about liberal attitudes in the midwestern region at this time add to the general understanding of this period of history.

- Age of Excess. New York: Niacmillan, 1965, pp. 386.

This book complements Ginger's earlier work, Altgeld's America, by analyzing the progressive, liberal movement on a nation-wide scale. His description of and comments on the excesses of the era are quite vivid, and although of an anti-big business nature, they do show the lack of extreme bias evident in early works on the subject.

Guthrie, John Alexander and Armstrong, George R. Western Forest Industry An Economic Outlook. Baltimore: John Hopkins Press, 1961, pp. 324.

Although this book is one of the more recent studies of the lumber industry, it is primarily concerned with the forestry management aspect of the industry. Also, since it pertains mostly to the future development of the industry, the book proved to be of only secondary worth to this paper.

Hauberg, John H. Weyerhaeuser and Denkmann. Rock Island, Illinois: Augustana Book Concern, 1957, pp. 167.

This work gives a detailed account of the early weyerhaeuser beginnings and of the long relationship between the Weyerhaeuser and Denkmann families. The value of the book is limited, however, by its obvious prejudice. Hauberg was married to a Denkmann, and both he and his son, John Hauberg, Jr., have been directors of the Weyerhaeuser Co.

Hays, Samuel P. The Response to Industrialism, 1885-1914. New York: Rand Vivally, 1957, pp. 211.

One of many books analyzing the period of industrialization following the Civil War, this work was read for general background information of the period. This book aided in better understanding the forces at work both for and against the industrial movernent.

Hibbard, B.H. History of Public Land Policies. Gloucester, Mass.: Peter Smith, 1924, pp. 591.

Although of little specific value to this paper, this book did give a good general description of the land policies which were in effect during the years covered by the developrnent of the lumber industry. A study of these policies and their effects on the settlement of the country was necessary to understand the actions of the railroads in respect to their land grants. 
Hidy, R.W., Hill, F.E. and Nevins, Allen. Timber and Men: The Weyerhaeuser Story. New York: Macmillan, 1963, pp. 704.

Timber and Nen was the chief reference source for the chapters centering around the development and significance of the Weyerhaeuser Company. Although highly flavored with pro-Weyerhaeuser sentiments, the book still remains the definitive work on the history of this firm. Intensively researched and extensively documented, the book not only gives a detailed account of the Weyerhaeuser interests, but it also reveals the general history of the lumber industry since the 1860's.

Hill, James J. Highways of Progress. New York: Doubleday, Page Co., 1910, pp. 354 .

Composed of the original thoughts and writings of the Empire Builder, Highways of Progress was extremely valuable in revealing the exact plans of Hill to develop the Pacific Northwest into an effective, profitable economy. An understanding of his concern for the development of the lumber industry in the region is primary to an understanding of why and how lumbering finally did become a dominate factor in the Pacific Northwest.

Ho, Franklin Y. H. Small Lumber Companies in Western Oregon. Washington, D.C.: Small Business Administration, 1963, pp. 119.

This study was very helpful in gaining a better understanding of the nature and problems of the smaller lumber firms in the Pacific Northwest. The statistical information was particularly useful in describing the present plight of this segement of the industry.

Holbrook, Stewart H. Burning An Empire. New York: Nacmillan, 1943, pp. 229.

With conservation a major consideration in any history of the lumber industry, Burning An Empire served to emphasize the results of the early lumber industry's lack of sound conservation policies. The book provided statistical information on the effects of the nation's major forest fires which gave a definite perspective to the threat posed by the industry's lack of conservation.

- Green Commonwealth. Seattle: Dogwood Press, 1945, pp. 163.

A short history of the Simpson Logging Company, this book was useful in adding to the general knowledge of the various large timber firms operating in the Pacific Northwest since the turn of the century.

- Holy Old Kackinaw. New York: NacMillan, 1939, pp. 290.

The worth of this book is that it is the only known general history of the lumber industry. Holbrook himself took part in the migration of the American logger and lumberman from New England to the Pacific Northwest, and his writing reflects his knowledge of the industry.

- James J. Hill. New York: Knopf, 1955, pp. 205.

This was the only separate biography of Hill to be found. Although: Holbrook's style of writing in this book seemed a bit superficial, it 
nonetheless did add to the general knowledge of the man and his relationship with the Iumber industry in Minnesota and the Pacific Nortinwest.

- Rocky lountain Revolution. New York: Holt, 1956, pp. 318. Not directly related to the study of the lumber industry, this book still was of secondary value. Holbrook in this work traces the activities of the Western Federation of Miners. This group was a forerunner of the IWW, and several of its principals later showed up in labor disputes involving the lumber industry in the Pacific Northwest.

- Story of American Railroads. New York: Crown, 1947, pp. 468. An extensively researched volume, the chief use of this book was in gaining a basic history of the railroad industry. This knowledge was necessary to understand the relationship between the railroads and lumbering.

pp. 374 .

- The Age of the Moguls. New York: Doubleday and Co., 1954,

This book represents a comparatively fair treatment of the various captains of industry of the late 1800's and early 1900's. Of primary interest to the writing of this paper were the chapter on James Hill. and also the author's comments on the worth of these individuals to America's development.

- The Far Corner. New York: Macmillan, 1952, pp. 270.

This general commentary on the history and nature of the Pacific Northwest was used primarily as a resource to verify certain aspects of the region's early history.

Horn, Stanley Fitzgerald. This Fascinating Lumber Business. Indianapolis: Bobbs-Merrill, 1951, pp. 313.

This Fascinating Lumber Business was read primarily for general information on the organization of the lumber business. Somewhat out of date now, little of value was derived from this book for this paper.

Hosmer, Paul. Now We're Loggin'. Portland: Binford, 1930, pp. 210.

Comprised of a series of magazine articles written by Hosmer concerning the individuals who make up a typical lumber firm, this book gave some priceless descriptions of some of the various attitudes evident in the early lumber industry.

Jensen, Vernon H. Lumber and Labor. New York: Farrar and Rhinehart, 1945, pp. 314.

In examining the relationship between the industry and its labor force, Jensen gives several enlightening descriptions of labor conditions in the early years of lumbering. These descriptions gave the necessary proof to the theory that the migratory nature of the industry led to econoric instability of the area in question. 
Johnson, Fmory. History of Domestic and Foreign Commerce of the United States. 2 vols. Washington, D.C.: Carnegie Institution, 1915, pp. 761.

These volumes were used to supply the necessary factual data to verify general assertions concerning the early ship building and shipping industries.

Josephson, Mathew. The Robber Barons. New York: Harcourt, Brace \& Co., 1934, pp. 474 .

Josephson's famous work exposing the supposed injustices which followed in the wake of the so-called "Robber Barons" was studied primarily to catch the mood of the muckrakers in their attack on the business leaders who emerged from the industrial revolution following the Civil Var.

Kennedy, Gail (ed.). Democracy and the Gospel of Wealth. Boston: Heath \& Co., 1949, pp. 116.

A collection of writings by various men discussing the pros and cons about the issue of the accumulation and disposition of wealth by the business moguls of the late $1800^{\prime}$ 's, this book was used to gain a feeling of the general attitudes which prevajiled during the period when Big Lumber was emerging. An understanding of these conflicting philosophies of wealth is basic to a general understanding of the era.

Kornbluh, Joyce L. (ed.). Rebel Voices, An I.W.W. Anthology. Ann Arbor: University of Michigan Press, 1964, pp. 419.

This valuable book with its original writings, songs, cartoons, etc., from the heyday of the IWW proved to be as entertaining as it was historically interesting and pertinent. The chapter on the IVIJ movement within the western lumber industry was of particular interest in the preparation of this paper.

Iister, Francis E. The Car Builder's Dictionary. New York: The Railroad Age Gazette, 1909, pp. 238.

A valuable reference work on the railroad car building industry, this book was of great help in researching the types of early railroad cars, their dimensions, and the materials used in their construction.

Lucia, Ellis. Head Rig. Portland: Overland Press, 1965, pp.238. Cormissioned by the West Coast Lumber Association to write a general history of the western lumber industry and of the WCLA, Lucia gives some interesting insights on this particular industrial association's origins, development, and significance. This information was good background for the comrnents concerning the influence of the large lumber companies on such industrial organizations.

McClelland, J.M., Jr. Longview, The Planned City. Portland: Binford, 1947 , pp. 158 .

This small volume was most beneficial in the writing of the history of the Weyerhaeuser vs. Long-3ell struggle over Longview, Washington. 
Longview, The Planned City goes into the background of Longview, exploring extensively R.A. Long's problems, his philosophy, his failings, and his significance to the modern lumber industry.

Niyers, Gustavus. History of the Great American Fortunes. New York: Randorn House, 1907, pp. 732 .

One of the better known of the early muckrakers at the turn of the century, Viyers was read not only for his chapters on James Hill and for his general anti-big business interpetation, but also for the extensive research information he provides. Hyers goes into great detajl, providing extensive factual proof for his arguments, and although he often allows his prejudices to get the better of his writing, the factual information remains valid.

Nettles, Curtis P. The Fmergence of a National Economy, 1775 - 1815. New York: Holt, Rinehart \& Winston, 1962, pp. 424.

This book proved to be of great value in researching the early beginnings of the lumber industry. Both the author's description of the beginnings of the lumber industry and his description of the general economy of the late 1700's and early 1800's are most enlightening.

Peffer, E. Louise. The Closing of the Public Domain : Disposal and Reservation Policies, $1900-1950$. Stanford: Stanford University Press, 1951, pp. 372.

Another general analysis of the government's land policies, this book while not specifically used for this paper did provide general background information on the subject of the land grants to the railroads.

Poor's Register of Corporations - 1966. New York: Standard \& Poor's Corp., 1966, pp. 3,193.

This volume provided the necessary information concerning the current officers of the Weyerhaeuser Company, the Great Northern Railroad, and the Northern Pacific Railroad.

Puter, Stephen A.D. Iooters of the Public Domain. Portland: Portland Printing House, 1908, pp. 495.

Puter's book is extremely important. for the insights the author gives on the various tactics practiced by the land speculators and Iumbermen at the turn of the century.

The Statutes of the United States of America: From larch, 1897 to March, 1899. Vol. 30, Washington: U.S. Government Printing Office, 1899.

The primary resource for the investigation of the Pettigrew Amendment and the lit. Rainier National Park Act, this volume of the original laws vividly shows their relationship to the Northern Pacific Railroad land grants.

Thompson, Fred. The I.W.W.: Its First Fifty Years, 1905 - 1955. Chicago: Industrial Workers of the World, 1955, pp. 203.

Interesting for its comments on the conditions of the early Pacific 
Northwest lumber industry, The I.W.W. was studied primarily to get a recent analysis of the conditions which gave rise to the I.W.i...

U.S., Bureau of Census. United States By Industries - Manufactures: 1905. Washington: U.S. Government Printing Office, 1907.

This volume was used for the purpose of gathering statistical information to support various arguments, assertions, and theories of this paper.

U.S., Department of Agriculture. Lumber Production in the United States, 1799 to 1946. Washington: U.S. Government Printing Ofice, 1947, pp. 233 .

Statistics on the lumber production of various states used in various charts of this paper were found in this volume.

U.S., Department of Commerce. Statistical Abstract of the United States. 4 vols., Washington: U.S. Government Printing Office, 1890, 1895, 1902 , and 1965.

These volumes were used for the purpose of gathering statistical data to support arguments of this paper.

U.S., Department of Commerce. The Lumber Industry. 4 vols., Washington: U.S. Government Printing office, 1914, pp. 1,498.

This extensive study was most helpful in getting the proper perspective on the extent of private timberland ownership at the turn of the century. These volumes proved to be a real mine of statistics and other information needed to prove various theories about the concentration of the timber resource into the hands of a few firms.

\section{Articles}

Appleman, Roy E. "Timber Empire From the Public Domain," Mississippi Valley Historical Review, XXVI, No. 2, Sept., 1939, pp. 193-208. Appleman's article was essential to gaining an unbiased perspective of the timberland transactions between the Weyerhaeuser Timber Company and the Northern Pacific Railroad. Although it tends to be written against these sales as being contrary to the public interest, the article is certainly not of the muckraking variety. This article together with the account in Timber and lien allowed me to see both sides of the issue.

Ellis, D.M. "The Forfeiture of Railroad Land Grants, 1867 - 1894," Mississippi Valley Historical Review, XXXIII, No. 1, June, 1946, pp. 27-60.

Although not dealing directly with the relationship between the railroads and the lumber industry, this article was valuable in that it analyzed the problems of the transcontinental railroads. liany times they over-extended their operations in order to acquire the land grants, only to find themselves later forced to sell portions of the grants or to have thern forfeited back to the public domain. The back- 
ground information provided in this article added to the understanding of the Northern Facific's situation in 1900.

Fries, Robert F. "The Kississippi River Logging Company and the Struggle for the Free Navigation of Logs, 1865 - 1900," Mississippi Valley Historical Review, XXXV, No. 3, December, 1948, pp. 429-48.

Fries' detailed account of the problems of the Mississippi River Logging Company in its struggle for access to the Chippewa River was important for it revealed not only the prevailing attitudes and practicies of the lumbermen of the late 1800's but also the attitude and philosophy of Frederick veyerhaeuser as he initiated his campaign to unite a select group of Mississippi River Iumbermen. This impartial account served to complement and verify the account of this period given in Timber and Ven.

Morgan, C.C. "Problem in the Appraisal of the Railroad Grants," Mississippi Valley Historical Review, YXXIII, No. 3, December, 1946, pp. 44354 .

This article was quite helpful in rounding out the background information on the nature of the land grants to the railroads. It added a great deal to the understanding of the articles by $\dot{H p p l e m a n}$ and Ellis and also to the information given in the 1914 government study of the issue, The Lumber Industry.

\section{$\underline{\text { Booklets }}$}

Reed College, The Forest Products Industry of Oregon: A Report of the Business Executive's Research Committee Sponsored by Lewis \& Clark College and Reed College. Portland: Reed College, 1956, pp. 56.

Stanford Research Institute. America's Demand for lood: 1929 - 1975. Stanford: Stanford University Press, 1954, pp. 94.

State of Oregon, Department of Forestry. Forest Resources of Oregon: Their Management and Use. Salem: State of Oregon Printing Office, $1961, \mathrm{pp} .63$.

U.S., Department of Agriculture. Historical Forestry Statistics of the U.S.: Washington: U.S. Government Printing Office, 1958, pp. 36.

- The Distribution of Softwood Lumber in the Middle Test. Washington: U.S. Government Printing Office, 1917, pp. 96.

- The Economic Importance of Timber in the United States. Washington: U.S. Governnent Printing Office, 1963, pp. 91.

West Coast Lumber Association. West Coast Lumber Facts. 2 vols., Seattle: West Coast Lumber Association, 1935 and 1937, pp. 25. 
Western Wood Products Association. Statistical Yearbook - 1965. Portland: Western Wood Products Association, 1965, po. 30.

All of the listed booklets were used primarily for the researching of statistical information required to support various points of this paper.

\section{Miscellaneous}

Tyler, Robert L.: "The Loyal Legion of Loggers and Lumbermen." Portland(?): Unpublished seminar paper in Oregon Historical Society collection, 1951, pp. 16.

This paper was used for the valuable insight it gave into the labor-management relations of the lumber industry in the Pacific Northwest in the early years of this century.

Weyerhaeuser Company. Annual Report - 1964. Tacoma: Weyerhaeuser Co., 1964 .

Valuable for production and sales figures of the current period, the Weyerhaeuser report aided in comparing the present situation with the early beginnings of the firm.

- Weyerhaeuser News. 7 vols., Tacoma: Weyerhaeuser Co., Warch, 1960; June, 1960; November, 1960; June, 1961; April, 1962; November, 1963; July, 1964; April, 1965.

These magazines, the official company house organ, were all studied for their general information of Weyerhaeuser history. Naturally written in favor of the company, the various articles of historical interest were nonetheless of great help. Although nothing was taken directly from these magazines, they served in several cases as the starting points for further research.

\section{Other Sources}

Personal interviews with Albert Erickson, St. Peter, Ninnesota. January, 1959 through August, 1960.

Personal interviews with Sanford Delyea, Nankato, Minnesota. January, 1959 through August, 1960.

Both of these interviewees gave first hand accounts of their long and varied experiences with the Neyerhaeuser organization. Of particular value were their reminiscences and analysis of the methods used by Neyerhaeuser and his synciicate to exploit the northwestern part of Minnesota.

Personal interview with a current wejerhaeuser official who prefers to remain unidentified, Portland, Oregon. April 22, 1966. 
In researching for information regarding the amounts of money currently spent by the Weyerhaeuser Company in such areas as advertising and research, I encountered typical Weyerhaeuser corporate secrecy in such matters. As there were no f'igures offered in annual reports and since letters of inquiry were unproductive, I had to rely on personal friendships to gain any information in these areas. Even this was claimed to be only a "close approximation." 